UNIVERSIDADE DE SÃO PAULO

INSTITUTO DE FÍSICA DE SÃOCARLOS

SUELEN CAMARGO

Caracterização funcional e estrutural da primeira arabinofuranosidase da família 62 de Thielavia terrestris dimerizada através de domain swapping 



\section{SUELEN CAMARGO}

Caracterização funcional e estrutural da primeira arabinofuranosidase da família 62 de Thielavia terrestris dimerizada através de domain swapping

Dissertação apresentada ao Programa de Pós-Graduação em Física do Instituto de Física de São Carlos da Universidade de São Paulo, para obtenção do título de Mestra em Ciências.

Área de concentração: Física Aplicada. Opção: Física Biomolecular

Orientador: Prof. Dr. João Renato Carvalho Muniz

Versão Corrigida

(versão original disponível na Unidade que aloja o Programa) 
AUTORIZO A REPRODUÇÃO E DIVULGAÇÃO TOTAL OU PARCIAL DESTE TRABALHO, POR QUALQUER MEIO CONVENCIONAL OU ELETRÔNICO PARA FINS DE ESTUDO E PESQUISA, DESDE QUE CITADA A FONTE.

Camargo, suelen

Caracterização funcional e estrutural da primeira arabinofuranosidase da família 62 de Thielavia terrestris dimerizada através de domain swapping / Suelen Camargo; orientador João Renato Carvalho Muniz -- São Carlos, 2018 . $101 \mathrm{p}$.

Dissertação (Mestrado - Programa de Pós-Graduação em Física Aplicada Biomolecular) -- Instituto de Física de São Carlos, Universidade de São Paulo, 2018.

1. Thielavia terrestris. 2. GH62. 3. Degradação de biomassa. 4. Domain swapping. I. Muniz, João Renato Carvalho, orient. II. Título. 


\section{AGRADECIMENTOS}

Primeiramente agradeço a minha família, por todo apoio, em especial meu pai Roderlei e minha mãe Silvana. Aos meus colegas de laboratório e toda equipe do LBest do grupo de cristalografia, que me auxiliaram em todos os momentos, em especial: Susana, Humberto, Tatiana, Evandro, Mateus, Leonardo, Paola, Renata, Thomás, Ana e Naty. Ao IFSC, Ricardo, Silvio, CTBE e a Capes pela infra estrutura e pelo apoio financeiro.

Aos antigos membros do Grupo de Biotecnologia, em especial: Mariana Zuliani, Hévila, Bruno, Caio e Danilo. Mesmo não estando mais presente entre nós, agradeço imensamente o Professor Milton Taidi Sonoda por toda a sabedoria e disposição em ajudar.

Aos professores Richard C. Garratt, Otavio Henrique Thiemann, Eduardo Horjales Reboredo e Alessandro Nascimento.

Ao meu orientador João Renato C. Muniz pela oportunidade e excelente orientação do começo ao fim. A Amanda Bernardes Muniz que sempre foi muito solicita a ajudar.

Aos colegas que de alguma maneira ajudaram a me manter focada e disposta a continuar traçando minha carreira: Wilson, Larissa, Laura, Cris, Lara, Carina, Mariana Azevedo, Maria Estela, Ariane e Paulo.

Ao professor Rolf A. Prade por ter muito bem me recebido em Oklahoma e contribuído para a minha formação como pesquisadora. 

"Sorte é o que acontece quando capacidade encontra se com oportunidade..."

Sêneca 



\section{RESUMO}

CAMARGO, S. Caracterização funcional e estrutural da primeira arabinofuranosidase da família 62 de Thielavia terrestris dimerizada através de domain swapping. 2018. 106 p. Dissertação (Mestrado em Ciências) - Instituto de Física de São Carlos, Universidade de São Paulo, São Carlos, 2018.

As enzimas hidrolíticas são consideradas, por plena definição, aquelas com a capacidade de realizar a reação de hidrólise. Devido à sua capacidade de degradar substâncias naturais, as enzimas hidrolíticas são de grande uso industrial e podem ser aplicadas nas indústrias têxtil, alimentar, farmacêutica, biocombustíveisagrícola, assim como na produção de derivados biotecnológicos de maior valor agregado. Conhecidas como enzimas que liberam arabinose e arabinofuranose, as arabinofuranosidases da família 62 são capazes de quebrar as conexões de arabinoxilanos. A importância biotecnológica de tais proteínas é desde o uso na agricultura à indústria. Elas podem ser utilizadas, por exemplo, em coquetéis na digestão de alimentos para animais, vinhos e para melhorar a eficiência de clarificação de sucos. Além disso, sua ação de deslignificação é promissora na degradação da biomassa para a produção de bicombustíveis. Este projeto procura realizar a clonagem, expressão heteróloga em bactérias e caracterização estrutural de uma $\alpha$-L-arabinofuranosidase do fungo termofilico Thielavia terrestris. Esta enzima pertence à família 62 das hidrolases de glicosídeos, que é conhecida por melhorar a ação das celulases e, portanto, de interesse na degradação da biomassa lignocelulósica, como o bagaço de cana-de-açúcar. Estudos biofísicos, bioquímicos e estruturais apresentados neste estudo buscam promover a compreensão dos mecanismos de ação desta enzima e sua aplicação na hidrólise do bagaço de cana-de-açúcar. $O$ trabalho destaca uma estrutura tridimensional inédita dentro da família 62 portadora de um fenômeno conhecido como domain swapping, possibilitando maiores investigações dentro do grupo das arabinofuranosidases.

Palavras chave: Thielavia terrestris. GH62. Degradação de biomassa. Domain swapping. 

ABSTRACT

CAMARGO, S. Functional and structural characterization of the first arabinofuranosidase of the Thielavia terrestris from family 62 dimerized through the domain swapping. 2018. 106 p. Dissertação (Mestrado em Ciências) - Instituto de Física de São Carlos, Universidade de São Paulo, São Carlos, 2018.

Hydrolytic enzymes are considered, for the full definition, those with the ability to perform the hydrolysis reaction. Because of their ability of degrading natural substances, hydrolytic enzymes are of wide industrial use and can be applied in the textile, food, pharmaceutical, and agricultural industries, in addition to being used in the production of biofuels. Known as enzymes that release arabinose, the arabinofuranosidases from family 62 are able to break arabinoxylans connections. The biotechnological importance of these proteins are used in the agricultural and industry. These enzymes are employed to process as cocktails for animal feed digestion, wines and to improve the efficiency of juices clarification. Moreover, its delignification action is promising in the biomass degradation for biofuel production. This project seeks to carry out cloning, heterologous expression in bacteria and characterization of an $\alpha$-L-arabinofuranosidase from thermophilic fungus Thielavia terrestris. This enzyme belonging to the glycoside hydrolase family 62 , which is known to enhance the action of cellulases, and thus of interest in the lignocellulosic biomass degradation such as sugar cane bagasse. This study will characterize the protein structure and biochemistry in order to understand the mechanism and optimal conditions of action. The biophysical, biochemical and structural tests seek to promote an understanding of the mechanisms of action of this enzyme and its application in the hydrolysis of sugarcane bagasse. The work shows a new threedimensional structure within the family 62 caused by a phenomenon known as domain swapping. Thus, it is possible to predict further investigations on the arabinofuranosidases group.

Keywords: Thielavia terrestris. GH62. Biomass degradation.Domain swapping. 



\section{LISTA DE FIGURAS}

Figura 1 - Gráfico comparativo entre PIB e consumo de biocombustíveis no ano de $2017 \ldots \ldots . .20$

Figura 2- Gráfico comparativo da produção de etanol e biodiesel entre o ano de 2005 a 2016.

Figura 3 - Gráficos comparativos de emissões de gases do efeito estufa (GEE)...... 22

Figura 4 - Desenho representando o complexo lignocelulósico. A estrutura de uma microfibrila e as moléculas de celulose envolvidas, se apresenta aumentada e prolongada, com destaque para as unidades de glicose ligadas entre si por ligações covalentes.

Figura 5- Desenho representativo da estrutura do material lignocelulósico.

Figura 6- Esquema com a rota da biomassa até o uso da hidrólise enzimática.......

Figura 7 - Esquema representativo das reações formando os aromatizantes de vinho, através da ação de enzimas.

Figura 8- Esquema representando a ação de cada enzima pertencente a famílias de GH51, GH43 Fonte: DEBOY et al. (27).

Figura 9- Esquema representando a ação de cada enzima pertencente a famílias de GH51, GH43 e GH62

Figura 10 - Primers e esquema representativo do clone

Figura 11 - Imagem representativa da técnica de Gel Nativo, que proteínas pequenas são menos conservadas pelas fibras do gel em comparação à proteínas maiores. Portanto as proteínas menores migram mais rapidamente.

Figura 12 - Diagrama de fases da solução de proteína em função da concentração e agentes precipitantes

Figura 13 - Gráfico explicativo sobre parâmetros cinéticos $\mathrm{K}_{\mathrm{m}}$ e $\mathrm{V}_{\max }$

Figura 14 - Esquema representativo do desenho dos oligonucleotídeos. F representa 0 foward contendo $10 \mathrm{pb}$ antes e $10 \mathrm{pb}$ depois da mutação. $\mathrm{R}$ representa o reverse, contendo $23 \mathrm{pb}$ complementares antes do início do foward...

Figura 15 - Eletroforese em gel de agarose 1\%. Primeiro poço representa marcador de massa molecular GeneRuler (1 kb plus ladder plus Life Technologies). A, B, C, D, E, F e G representam as amostras de DNA de Thielavia terrestris após a extração a partir dos micélios do fungo.

Figura 16 - Eletroforese de gel de agarose 1\% representando o vetor linearizado acima da banda de $1500 \mathrm{pb}$ e o gene da eGFP na banda de $750 \mathrm{pb}$ em 1 e 2. A amostra foi dividida em dois poços, pois havia grande quantidade de DNA.....

Figura 17- Eletroforese de gel de agarose 1\% representando o resultado da reação de PCR referente a hibridização entre o vetor e fragmento gênico, com aproximadamente $6.500 \mathrm{pb}, \mathrm{em}$

1 e 2 . 
Figura 18 - Gel de poliacrilamida contendo a expressão da TtGH62 utilizando meio autoindutor. Eletroforese em Gel de SDS-Page $12 \%$ em A e B. A: Representa as amostras logo após a expressão, sendo 10 extrato bruto, 2 o flowthru da primeira purificação e 3 a fração proteica após a primeira purificação, todos tendo como referencia o MM (marcador de massa molecular). B: Representa as amostras após a primeira purificação e após a clivagem com TEV protease, sendo 1 resultado da primeira purificação, 2 e 3

são mesmas amostras da proteína após a clivagem da cauda de histidina

Figura 19 - Gel de poliacrilamida contendo as amostras da primeira purificação por afinidade da TtGH62. Eletroforese em Gel de SDS-Page 12\%. As amostras 1 a 9 são referentes aos tampões: A1, A2, A3, A4, A5, A6, A7, A8 e A9, respectivamente. MM é referente ao marcador de massa molecular.....

Figura 20 - Gel de poliacrilamida contendo as amostras da segunda purificação por cromatografia de exclusão por massa molecular da TtGH62. 1 a 9 representam as alíquotas coletados durante a purificação e MM é o marcador de massa molecular.

Figura 21- Espectro de eluição da Cromatografia de Exclusão Molecular. O pico que atinge 700 mAU representa a fração eluida da proteína.

Figura 22 - Imagem do Gel Nativo.1,2,3,4,5) TtGH62 após cromatografia de afinidade em diferentes concentrações, todas na faixa de $140 \mathrm{kDa}$. MM) marcador molecular 64

Figura 23 - Gráfico de estabilidade térmica. Valores da Temperatura de melting de acordo com os tampões utilizados na técnica de DSF

Figura 24 - Foto dos cristais obtidos no kit Classic a partir de $20 \mathrm{mg} / \mathrm{mL}$ de proteína $T t \mathrm{GH} 62$, após 30 dias conservados a $18 \stackrel{\circ}{\circ} \mathrm{C}$

Figura 25- Imagem do padrão de difração obtido a partir do cristal de TtGH62.

Figura 26 - Imagem da estrutura tridimensional da enzima TtGH62 após o refinamento. Em verde são representados os íons Cálcio

Figura 27- Esquema representativo da subunidade de TtGH62 e sua forma tetramérica

Figura 28 - Comparação da proteína TtGH62 e proteínas homólogas depositadas no PDB. a) Estruturas similares de TtGH62 alinhadas, destacando a formação de domain swapping para TtGH62 onde os resíduos D58 e K57 no sítio de atividade e também a molécula de etileno glicol (EtGly) de B com relação à simetria: TtGH62. b) Resíduos no local ativo de TtGH62 semelhante com seu respectivo código (colorido por traços) e ligantes: TtGH62 EtGly ciano; ScAbf62-3MWY TRIS tampão (TRS) verde; PaAbf62A TRIS tampão (TRS) magenta; SthAraf62A4O8N BIS-TRIS tampão (BTB) amarelo e SthAraf62A-4O8O Alfa-LArabinofuranose (AHR) vermelho. Os íons de cálcio ( $\mathrm{Ca} 2+$ ) são representados como esferas com raios arbitrários coloridos por cadeias

Figura 29- Imagem com sítio ativo de TtGH62 com substrato Arabinano sobreposto ao etilenoglicol e os aminoácidos que interagem ao redor do sítio..... 76

Figura 30- Vista detalhada do TtGH62 domain swapping, o seu sítio ativo e a ponte de dissulfeto.

a) Dímero domain swapping de TtGH62 que mostra os terminais $\mathrm{N}$ e $\mathrm{C}$ das suas cadeias de monômeros, respectivamente, que estão ligados através da ligação dissulfeto destacada, onde podem ser cinco pás fazendo o sistema dimérico necessário para estabilizar a estrutura. Os íons de cálcio (Ca 2+) são 
representados como esferas coloridas verdes, sulfatos (SO4-) e ligantes de etileno glicol (EtGLy) também podem ser observados. b) Uma visão detalhada do sitio ativo com ligações de hidrogênio entre moléculas de água que mediam interações para EtGly e também uma ponte salina entre resíduos Hys283 e Asp58. c) Vista detalhada da ligação dissulfeto entre A: Cys32 (pertencente à região C-terminal) e B: Cys300 (pertencente àregião $\mathrm{N}$-terminal).

Figura 31 - Gráfico mostrando a atividade relativa em da TtGH62 em função dos pHs, sendo que o melhor $\mathrm{pH}$ é 4,5 .

Figura 32- Gráfico da atividade relativa de TtGH62 em função da temperatura. A melhor temperatura.

Figura 33-Gráfico comparando a atividade relativa da TtGH62 a diferentes substratos poliméricos

Figura 34- Gráficos medindo a velocidade da reação sob diferentes concentrações de substrato. A) Curva de Michaelis-Menten para TtGH62 utilizando Arabinoxilano de trigo como substrato. B) Curva de Michaelis-Menten para TtGH62 utilizando Arabinano como substrato....

Figura 35 - Gráficos medindo a velocidade da reação sob diferentes concentrações de substrato. A) Curva de Michaelis-Menten para SthAbf62A utilizando Arabinoxilano de trigo como substrato. B) Curva de Michaelis-Menten para SthAbf62A utilizando Arabinano como substrato

Figura 36- Imagem do gel de agarose $0,8 \%$ após eletroforese. Resultado da reação de primers com vetor, com as amostras amplificadas. 1) Clone contendo a mutação ASP58. 2) Clone contendo a mutação Asp165. 3) Clone contendo a mutação Glu217. 4) Clone contendo a mutação Cys300

Figura 37 - Imagem do gel de agarose $0,8 \%$ após eletroforese. Resultado do ensaio de PCR de colônia contendo 5 amostras referentes aos clones Asp58 e Cys300. 1,2) Clone com mutação Asp58. 3,4,5) Clone com mutação Cys300. As amostras estão localizadas no peso de aproximadamente $7 \mathrm{~kb}$, o que corresponde ao peso do vetor $(6.800 \mathrm{pb})$

Figura 38 - Gel SDS-PAGE 15\% com as amostras das proteínas heterólogas mutantes, sendo mutante 1 referente a mutação Asp58, mutante 2 referente a mutação Asp165, mutante 3 referente a mutação Glu217 e mutante 4 referente a mutação Cys300. MM) Marcador de massa molecular. 1) Extrato bruto do selvagem. 2) Mutante 1 após purificações. 3) Mutante 2 após purificações. 4) Mutante 1 antes da purificação. 5) Mutante 3 após purificações. 6) Selvagem após purificações.

7) Mutante 4 após purificações

Figura 39 - Gel SDS-PAGE 15\% com as amostras de proteínas mutantes. 1) Mutante referente a mutação Asp165. 2) Mutante referente a mutação Glu217. 3) Mutante referente a mutação Cys300. 



\section{LISTA DE TABELAS}

Tabela 1 - Condições da reação de PCR utilizadas no protocolo de clonagem LIC (Ligase

Independent Cloning).

Tabela 2 - Condições da reação de PCR no processo de produção dos clones....

Tabela 3 - Estabilidade da enzima TtGH62 pela técnica DSF através da variação do pH e concentração de sal. Os tampões que representam maior estabilidade para a proteína estão destacados em verde escuro e aqueles que são avaliados com menor estabilidade para a proteína são destacados em vermelho escuro....

Tabela 4 - Estatísticas cristalográficas referentes a coleta, processamento e refinamento do cristal da TtGH62. Valores entre parênteses referem-se à camada mais alta de resolução......69

Tabela 5 - Tabela comparativa de proteínas da família GH62 em relação a localização do sítio de ligação ao Cálcio.

Tabela 6 - Valores de $\mathrm{K}_{\mathrm{M}}$ e $\mathrm{k}_{\text {cat }}$ para TtGH62 nos substratos pNP-aAraF, arabinoxilano de trigo e arabinano

Tabela 7 - Valores de $\mathrm{K}_{\mathrm{M}}$ e $\mathrm{k}_{\mathrm{cat}}$ para SthAbf62A nos substratos pNP-aAraF, arabinoxilano de trigo e arabinano

Tabela 8 - Comparação dos parâmetros cinéticos de TtGH62 e SthAbf62A em substratos pNPaAraF, arabinoxilano de trigo e arabinano

Tabela 9 - Tabela contendo os oligonucleotídeos utilizados nos ensaios de mutação sítio dirigida 



\section{SUMÁRIO}

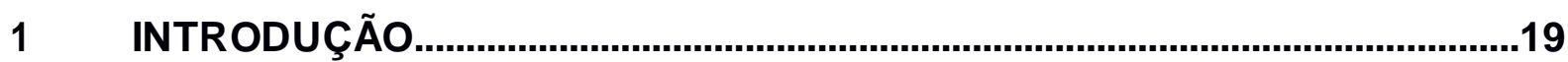

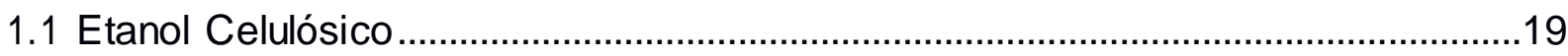

1.1.1 Combustíveis e a vantagem do etanol celulósico ...............................................19

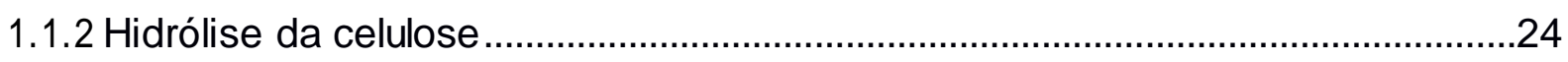

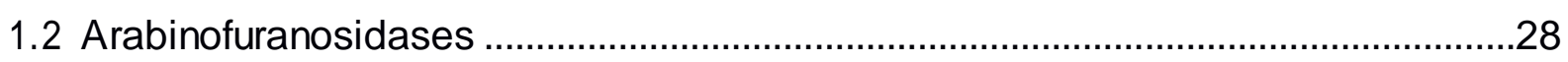

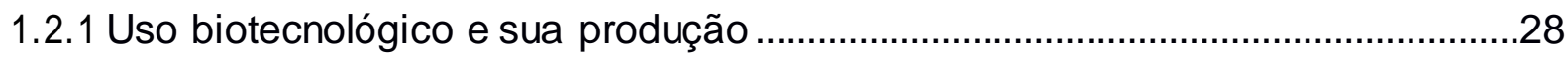

1.2.2 A bioquímica e produção das arabinofuranosidases .............................................33

1.2.3 Alpha - I - arabinofuranosidase de Thielavia terrestris ........................................35

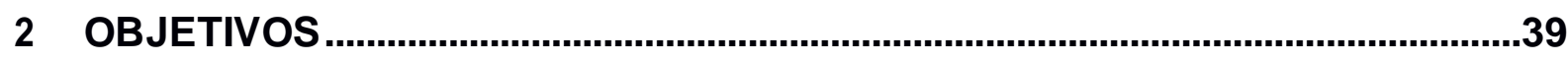

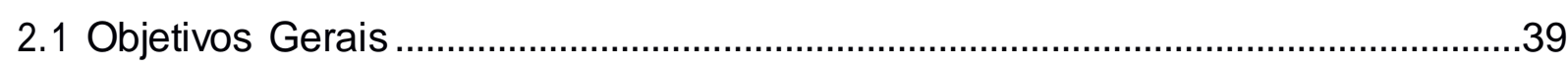

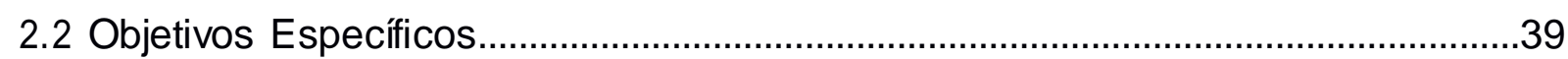

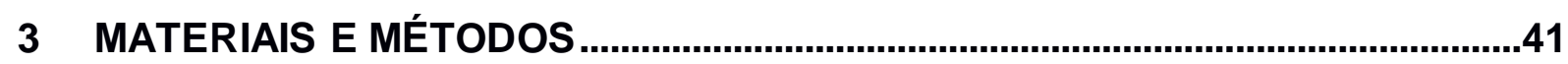

3.1 Microrganismo e cultivo ……………………………...........................................

3.2 Extração do DNA de Thielavia terrestris ...............................................................

3.3 Clonagem, transformação e expressão heteróloga .................................................42

3.4 Tratamento do pelletcelular e Purificação por Cromatografia.................................45

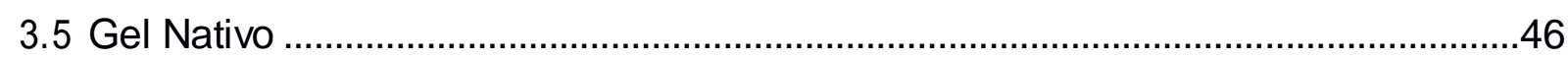

3.6 Ensaios de Cristalização e Coleta de Dados de Difração de Raios X....................47

3.7 Determinação e refinamento da estrutura................................................................49

3.8 Fluorimetria diferencial de varredura (DSF) .....................................................50

3.9 Ensaios de Atividade Enzimática - Painel de Substratos, Curva de atividade em diferentes pH's e Curva de atividade em diferentes temperaturas .........................51

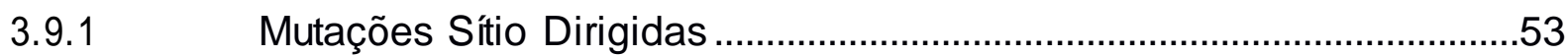

3.9.2 Preparação de Células Competentes e Transformação............................55

3.9.3 Expressão, purificação e teste de atividade enzimática .............................56

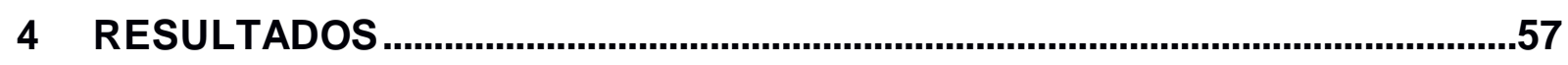

4.1 Clonagem, transformação, purificação, estado oligomérico e DFS .........................57

4.2 Ensaios de cristalização e resolução da estrutura 3D ............................................67

4.3 Caracterização Enzimática .....................................................................................78

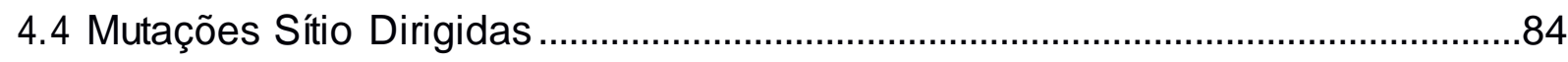

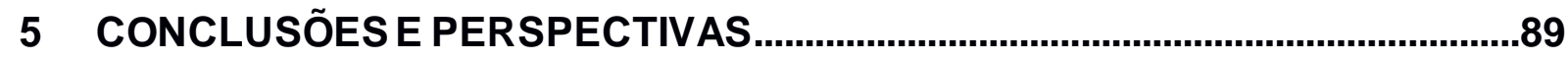

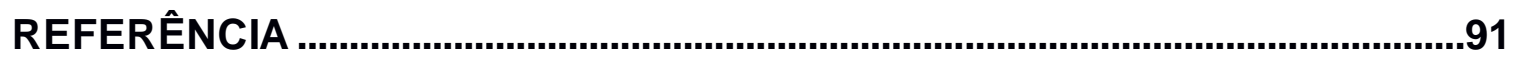

ANEXOS 



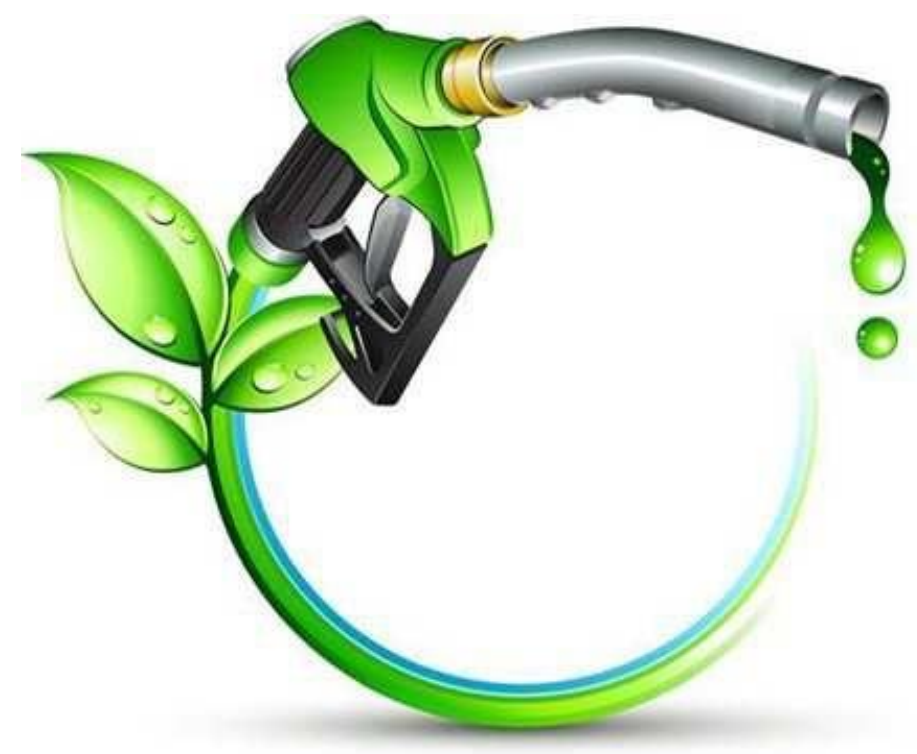

\section{INTRODUÇÃO}

\subsection{ETANOL CELULÓSICO}

\subsubsection{Combustíveis e a vantagem do etanol celulósico}

O Brasil é um país cuja a economia se classifica como emergente, indicando que ainda há muito a se explorar em diversos setores de produção. A cadeia de produção de combustíveis ainda precisa ser mais consolidada e possui projetos para avançar essa demanda energética. Um deles é a promoção de uma bioeconomia, com adoção de biocombustíveis que representa uma alternativa mais ecológica e oferece um estímulo para outras economias, como, por exemplo, na agricultura (cadeia de produção de matéria prima para muitos biocombustíveis) com plantações de oleaginosas e gramíneas. Além de criar novos nichos socioeconômicos, o investimento em energia limpa reduz a necessidade de importar combustíveis derivados do petróleo. (1-2)

Um dos fatores que ajudam a definir o desenvolvimento econômico de um país é seu consumo de energia, o que reflete também na qualidade de vida de uma 
sociedade. Dados publicados pelo Ipea (Instituto de Pesquisa Econômica Aplicada) indicam a relação entre a variação do PIB (produto interno bruto) e do consumo de biocombustíveis, evidenciando que ambos crescem e decaem juntamente. Logo, é notório que o consumo de energia e o PIB estão intimamente ligados. $(1,5)$

A substituição de combustíveis derivados do petróleo por biocombustíveis como etanol e biodiesel geram impactos econômicos. O gráfico da Figura 1 mostra que alguns estados sofreram uma redução do PIB por conta da substituição dos combustíveis fósseis por combustíveis de origem biológica não fóssil. Muitos estados como Mato Grosso, Alagoas e Tocantins mostram uma variação do PIB favorável na substituição dos biocombustíveis, principalmente pelas facilidades oferecidas na região, como plantações de soja e outras culturas das quais parte da safra que não se aproveitou poderia ser usada como matéria prima em indústrias de biocombustíveis. Já as regiões com saldo negativo se justificam pela composição regional da produção ser voltada para extração de petróleo e gás. Tais regiões seriam Amazonas, Sergipe e Rio de Janeiro: com maior representatividade na produção de combustíveis derivados do petróleo. Estados como São Paulo e Bahia são afetados pela substituição com pequenas variações.(6)

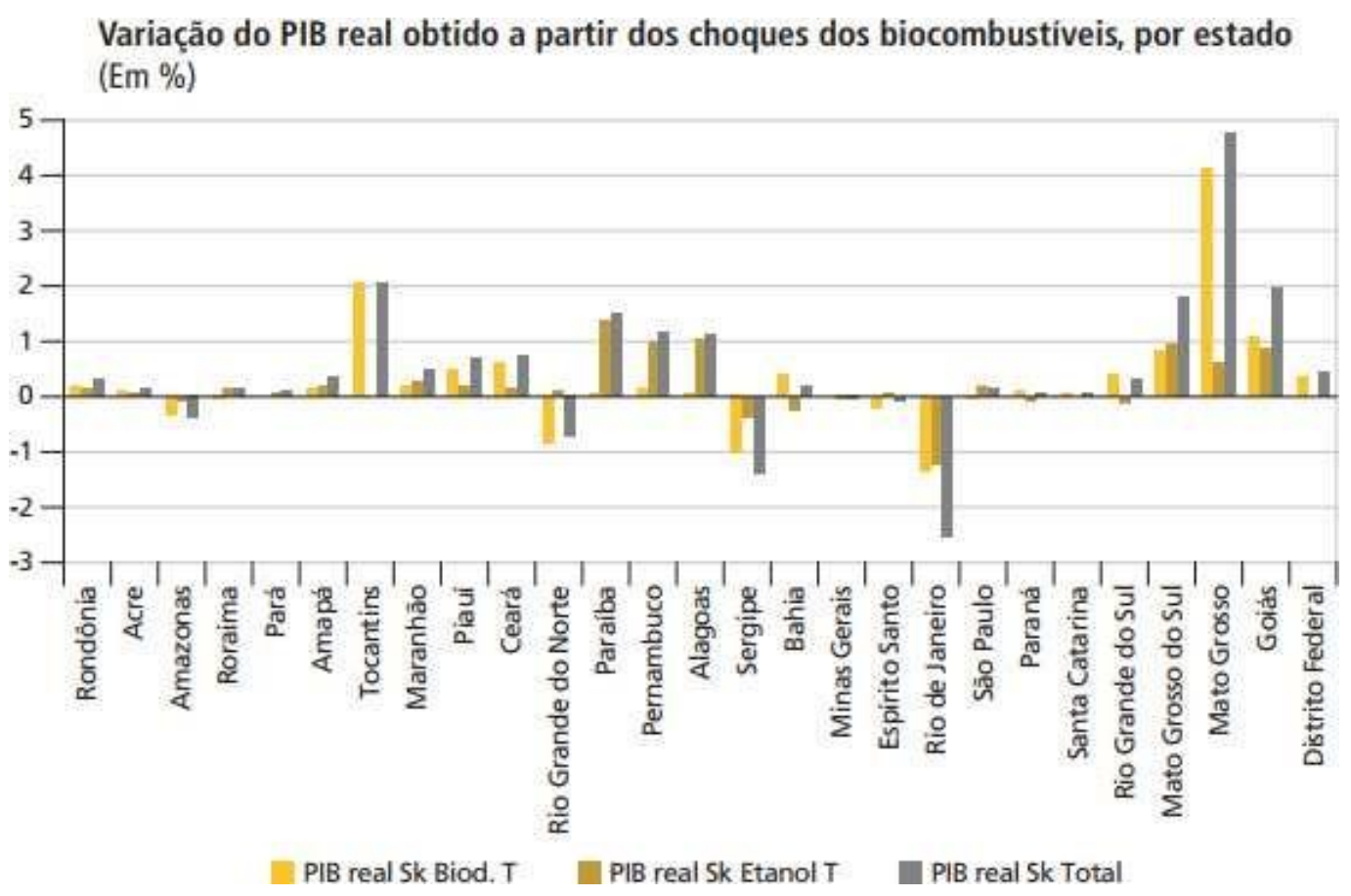

Figura 1 - Gráfico comparativo entre PIB e consumo de biocombustíveis no ano de 2017.

Fonte: SANTOS; FERREIRA FILHO (6) 
Isso ocorre pelo fato de ser em regiões que possuem grandes produtores de combustíveis de origem biológica não fóssil como também de combustíveis fósseis, tornando os efeitos do choque iguais em ambos os casos. (6)

Tal cenário mostra que a substituição dos combustíveis fósseis por alternativas renováveis ainda está em transição e crescimento. O incentivo para que o biocombustível seja de fato implantado em determinada região é a facilidade em encontrar a matéria prima e construções de indústrias de biodiesel e etanol. Como tais medidas ainda não foram implantadas em todo o território nacional, o Brasil se encontra com uma produção de atividades relacionadas à produção de biocombustíveis ainda disforme. $(3,4,6)$

\section{BRASIL: PRODUÇÃO DE ETANOL E BIODIESEL}

\section{$\left(\mathrm{MIL} \mathrm{m}^{3}\right.$ )}

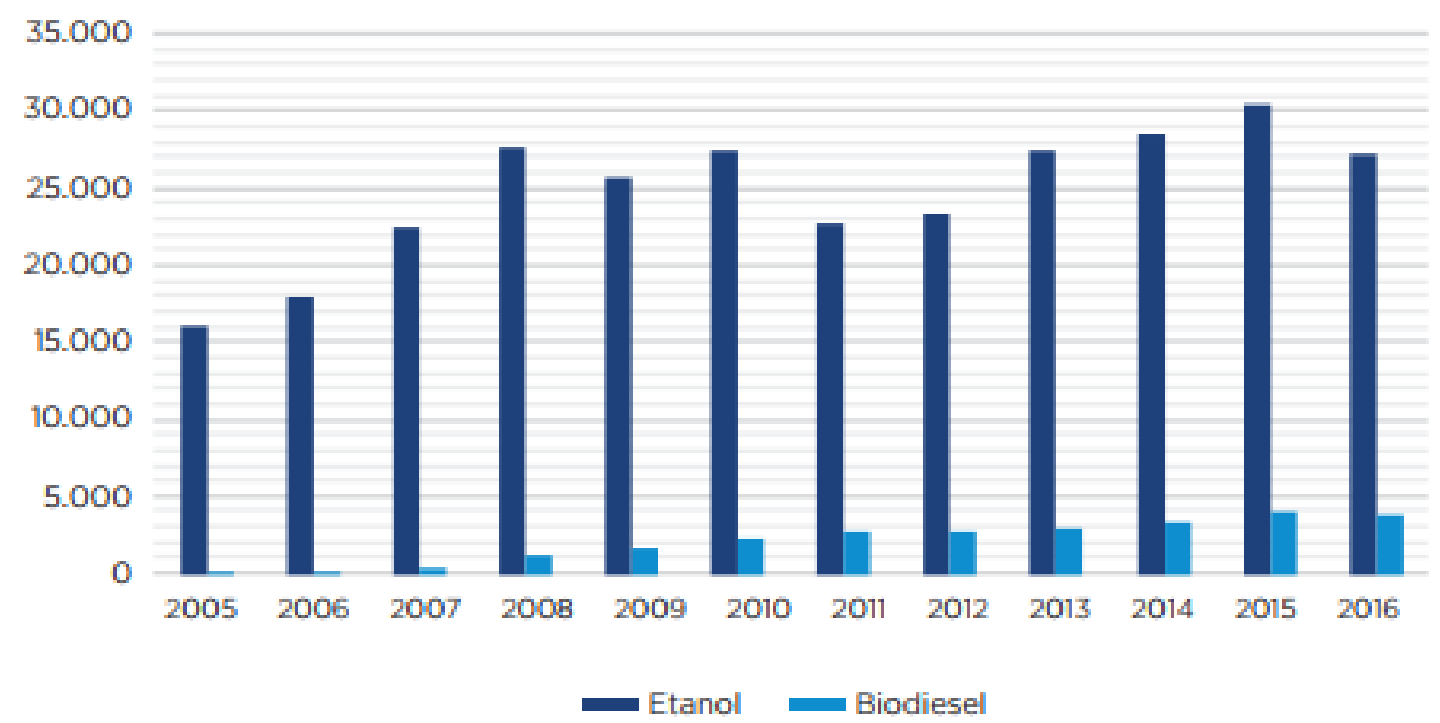

Figura 2-Gráfico comparativo da produção de etanol e biodiesel entre o ano de 2005 a 2016. Fonte: BRASIL. (7)

A produção de etanol não celulósico e biodiesel vem se mantendo com gradativo aumento ao longo dos anos, como demonstra a Figura 2. O combustível mais utilizado ainda é a gasolina, proveniente do petróleo, que possui pouca estabilidade de preço, além de ser uma fonte de energia esgotável. Portanto, as fontes de energia devem ser oriundas de matéria prima abundante e renovável, como é o caso da cana-de-açúcar. Hoje o Brasil possui mais de $80 \%$ de seus veículos rodando com bioetanol, no entanto a produção do álcool a partir de 
bagaço de cana-de-açúcar ainda é um desafio para o Brasil, visto que o desenvolvimento de novas tecnologias sustentáveis ainda é recente e que precisa aprimorar mais o conhecimento básico necessário para o desenvolvimento de tecnologias capazes de obter energia a partir de materiais lignocelulósicos. $(3,7)$

Mesmo a produção de etanol sendo um desafio por ser uma substituição de combustível recente, a responsabilidade ambiental está sendo cada vez mais difundida na sociedade, visto que o conceito de sustentabilidade já se insere no âmbito industrial e se torna um aliado ao desenvolvimento econômico. A gestão ambiental no Brasil atravessa um cenário crítico, que envolve um conflito de interesses entre proteção do meio ambiente e desenvolvimento econômico; pois por muitos anos que não era possível progredir industrialmente sem afetar a natureza (10). É de conhecimento mundial que mudanças climáticas vêm ocorrendo ao longo das décadas, as quais se justificam pelo resultado de um desenvolvimento econômico que a pouco tempo começou a se preocupar com a biosfera (11). O acúmulo de gás carbônico gerado pela queima de combustíveis fósseis é preocupante, o que demonstra a necessidade de potencializar a produção de combustíveis renováveis, como o etanol. (10)

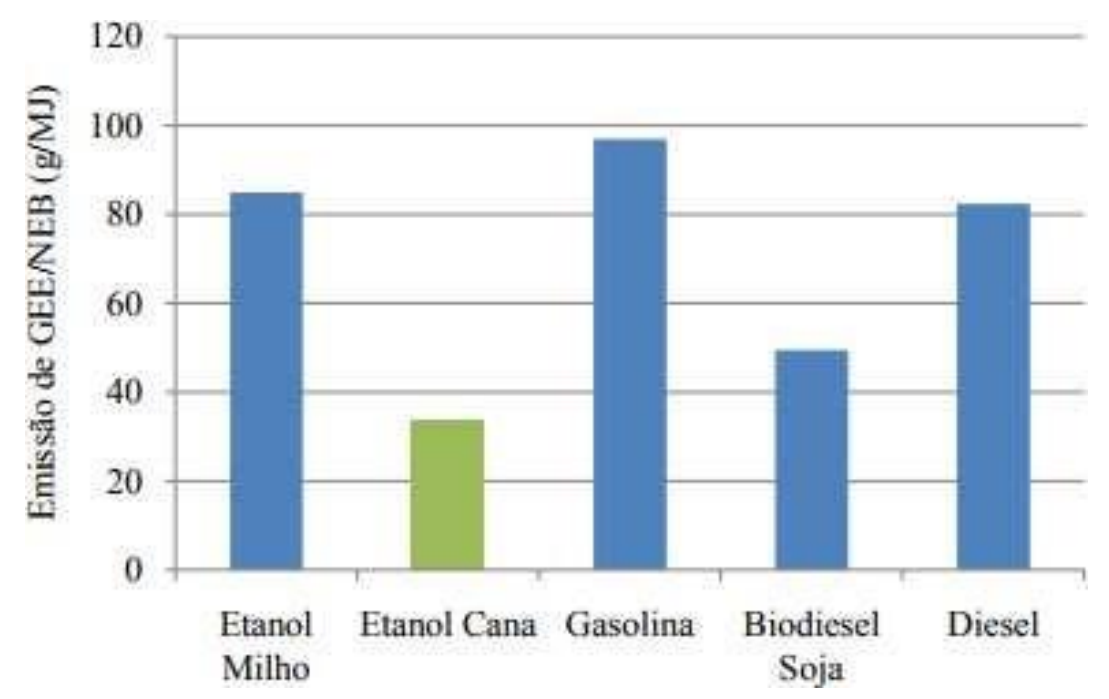

Figura 3 - Gráficos comparativos de emissões de gases do efeito estufa (GEE).

Fonte: MOTTA. (8)

A cana-de-açúcar demonstra ser uma boa alternativa como fonte de energia, principalmente pela alta capacidade fotossintética, boa adaptação ao clima 
brasileiro e alta produtividade (a cada hectare de cultivo gera aproximadamente 7.000 litros de álcool). Em questões ambientais também há vantagens em seu uso devido ao fato de reduzir mais da metade das emissões de GEE. Comparando o cultivo da cana-de-açúcar a outros insumos agrícolas como o milho (matéria prima dos Estados Unidos da América) percebe se benefícios em relação a sua maior produtividade, menor emissão de GEE e maior balanço energético, como mostra o gráfico da Figura 3. $(8,10)$

A produção de combustíveis renováveis é economicamente atrativa quando comparada à produção de combustíveis derivados do petróleo. No entanto, a matéria prima empregada para a fabricação dos combustíveis renováveis ainda tem alto custo. O uso de culturas alimentícias para a produção de combustíveis cria um certo conflito com a produção de alimentos, portanto uma forma de aproveitar essa alternativa é produzindo bicombustíveis com coprodutos da cana-de-açúca, ou seja, àqueles que são feitos a partir de matéria prima residual do processo anterior. O resíduo represente cerca de $10 \%$ da geração total da produção de canade- açúcar e quase sempre tem seu uso rejeitado e causa problemas ambientais. A biomassa a ser usada como matéria prima tem diversas definições, mas é considerada toda a matéria orgânica que após a queima ou decomposição produz qualquer forma de energia, de forma direta ou não. Portanto, pode se dizer que o termo "biomassa" se refere a matéria vegetal proveniente da fotossíntese, com potencial de energia química oriunda de reações luminosas. No caso do Brasil, o insumo agrícola para a produção de etanol de primeira geração é a cana-deaçúcar, sendo assim a matéria prima para a produção de etanol de segunda geração é o bagaço de cana-de-açúcar. $(7,12)$

Apesar da infraestrutura e maquinaria necessária para a produção do etanol celulósico já estar em andamento, o Brasil ainda precisa enfrentar algumas barreiras para progredir em novas tecnologias na produção de álcool de segunda geração. O conhecimento científico necessário para a geração desse bicombustível a larga escala ainda é mediano e requer maior importância nacional para que seja de fato consolidado. A busca por inovações na produção de etanol via bagaço de cana-de-açúcar é uma alternativa para melhorar ainda mais a questão sobre combustíveis no país. (9)

O Brasil se encontra como um dos maiores produtores de etanol do mundo através do processamento da cana-de-açúcar, aproximadamente $27 \%$ de 
contribuição, junto aos EUA que utiliza o milho como sua matéria prima e contribui com praticamente o dobro. (14) De acordo com dados do CONAB (Companhia Nacional de Abastecimento), estima se que o Brasil terá uma produção total na safra entre 2016 e 2017 de 30 bilhões de litros de etanol, a qual se torna um desafio a ser alcançado baseado especialmente na geração de etanol a partir de matéria lignocelulósica. (15) A plantação de cana-de- açúcar no Brasil desperta valia e interesse principalmente por refletir em uma matriz energética limpa, já que em 2014, 60\% da energia foi considerada renovável em contraste com a média mundial de apenas 14,2\%. (16)Em vista disso, a produção do etanol celulósico não reflete simplesmente uma alternativa a energias limpas, mas sim uma alternativa vantajosa por não precisar de um aumento da área de plantio, em razão de utilizar os resíduos das colheitas já existentes, como o bagaço da cana-de-açúcar. Tal reaproveitamento só é possível devido a técnicas inovadoras serem empregadas para a decomposição do bagaço, como o uso de enzimas aliada a pré-tratamentos alternativos. Um recente trabalho comprova que o bagaço sozinho está mais apto a sacarificação enzimática e fermentação alcoólica em comparação à palha e ponteiros isolados (folhas verdes da cana-de-açúcar) e, curiosamente, possuindo maior rendimento ainda se misturado às demais partes das plantas. (17-18)A energia elétrica gerada a partir do bagaço e da palha da cana-de-açúcar é chamada de bioeletricidade, a qual se contrapõe à produção de etanol de $2^{\text {a }}$ geração, já que ambas as práticas utilizam os mesmos resíduos. No entanto, um estudo detalhado demonstrou que o emprego do bagaço para geração de etanol é consideravelmente mais benéfico quando se possui uma comercialização mais acessível de melhorias tecnológicas do processo e de enzimas de baixo custo, aliado ao uso total das partes da planta para o processo. (19)O etanol celulósico é uma alternativa considerada "limpa", que necessita de inovações tecnológicas constantes, por se tratar de uma cadeia de processos complexos e que atualmente lida com tecnologias rudimentares. (20)

\subsubsection{Hidrólise da celulose}

Para que o etanol de segunda geração seja produzido, há várias formas de pré tratamentos. Entre os mais mais utilizados estão: tratamento químico com ácidos e ação de enzimas celulases capazes de hidrolisar a biomassa. Entre as duas alternativas, o tratamento via ácidos é desvantajoso 
pelo fato de ser corrosivo e gerar altos custos com a produção do mesmo e com reatores sofisticados para obter altos rendimentos. Já o uso de coquetéis enzimáticos, mesmo sendo uma tecnologia que implica grandes despesas, demonstra ser uma via mais eficiente e sustentável, dado que promove o rompimento de polissacarídeos que estão ligados à lignina através de ligações covalentes e pontes de hidrogênio, possibilitando uma melhor hidrólise. (21)

A produção de etanol é feita por meio da fermentação da celulose, um composto insolúvel, o qual através da decomposição é transformado em açúcares simples solúveis. Para que esse processo ocorra são empregadas as enzimas celulases, oriundas de microrganismos como fungos e bactérias. $O$ uso de tais enzimas é fundamental para tornar o processo cada vez mais eficiente e menos dispendioso. (22)

As enzimas celulases, como o próprio nome sugere, são capazes de degradar celulose. A celulose é o principal componente da parede celular das plantas. Graças ao processo de fotossíntese, ocorre a renovação das camadas que compõem a parede celular, uma estrutura rígida formada por microfibrilas de celulose (36 moléculas de celulose depositadas uma sobre a outra) juntamente a uma matriz de polissacarídeos (pectinas, proteínas e hemicelulose) exemplificado nas Figura 4 e Figura 5. Toda essa estrutura the confere funções biológicas fundamentais para a planta, como: regulação do volume celular, proteção contra agentes invasores e resistência mecânica. A estrutura química da celulose é baseada em um polímero linear simples composto por glicoses com ligações glicosídicas tipo $\beta-1,4 .(23)$ 

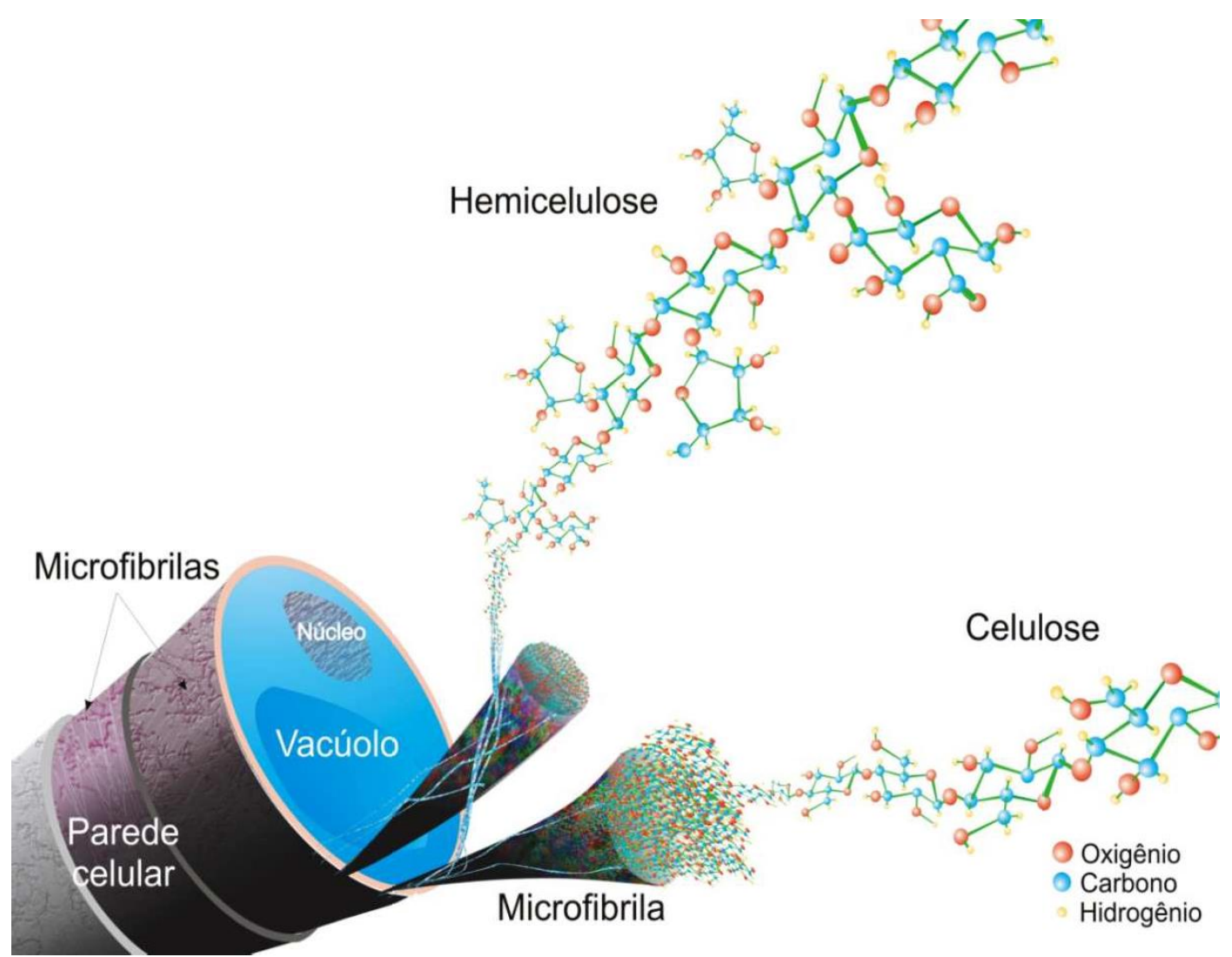

Figura 4 - Desenho representando o complexo lignocelulósico. A estrutura de uma microfibrila e as moléculas de celulose envolvidas, se apresenta aumentada e prolongada, com destaque para as unidades de glicose ligadas entre si por ligações covalentes.

Fonte: Adaptada de BUCKERIDGE etal. (2)

Ainda que seja uma estrutura estabilizada por ligações de hidrogênio intramoleculares, o que garante a formação de fibrilas de celulose são as ligações intermoleculares. As fibrilas tratam-se, basicamente, da união entre estruturas fortemente ordenadas, que confere uma alta recalcitrância à parede celular. $(2,23)$

As fibrilas caracterizam-se por terem regiões bastante crist linas (grau de ordenação alto) e outras denominadas regiões amorfas (grau de ordenação baixo). Entre as regiões, o estado amorfo é o mais sujeito a ação de enzimas degradativas, no entanto, uma resistência é conferida às fibrilas de celulose através do acúmulo de lignina e hemiceluloses, formando uma camada superior que dificulta a ação enzimática. Por esse motivo, a parede celular acaba se tornando um componente insolúvel em muitos solventes e de grande resistência à tensão, como pode ser observado na Figura 5. (23-24) 


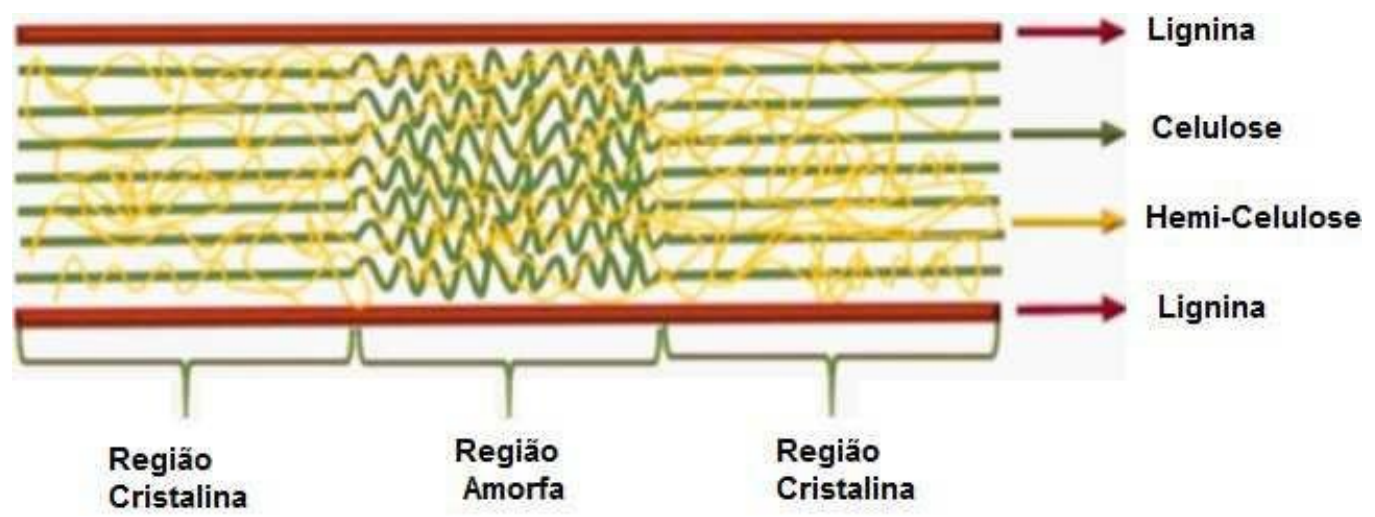

Figura 5-Desenho representativo da estrutura do material lignocelulósico.

Fonte: Adaptada de ERGÜN et al. (40)

Mesmo havendo essa recalcitrância da parede celular, há pré-tratamentos que conseguem diminuir essa barreira, através da remoção de lignina e quebra da região cristalina da celulose. Os pré-tratamentos utilizados podem ser ácidos, sendo esses ácidos diluídos (concentração menor que $5 \%$ da relação massa e volume) ou concentrados (concentração maior que $5 \%$ da relação massa e volume). No entanto, ambos os processos possuem algumas dificuldades, como: limite pela corrosão, alto custo de recuperação do ácido, equipamentos caros e produtos de degradação que possuem ação inibitória a fermentação microbiana. $(26,28)$

Outra opção é a hidrólise enzimática, baseada em utilizar proteínas de ação degradativa a fim de gerar açúcares fermentescíveis. Por ser um tratamento biológico, muitas vezes não apresenta resíduos tóxicos a microrganismos e ao meio ambiente, além de eliminar problemas relacionados à corrosão, exemplificado na Figura 6. O maior desafio do processo não é apenas a elaboração de bons coquetéis enzimáticos, mas também a comercialização dos mesmos a preços mais atrativos. $(23,29-30)$ 


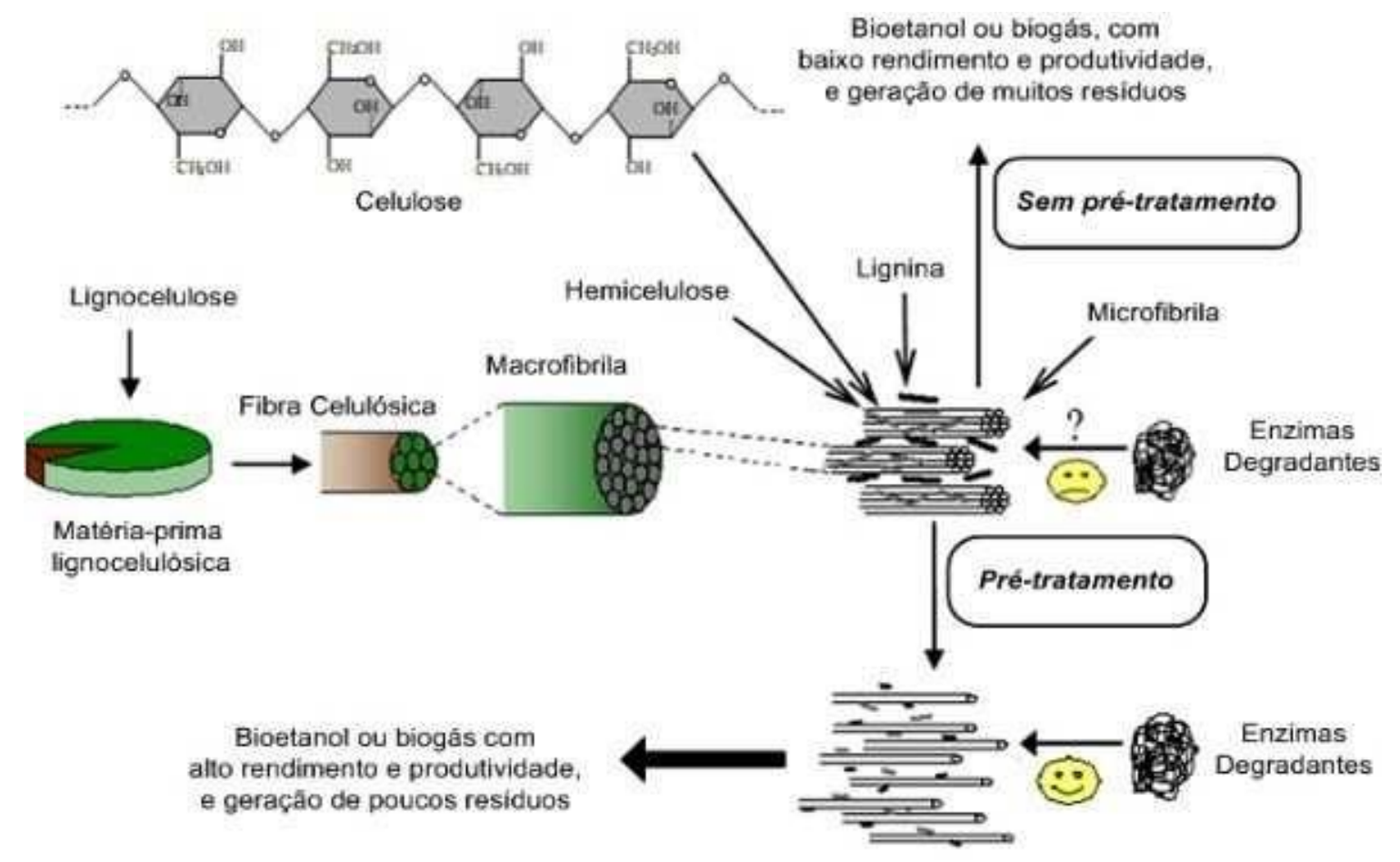

Figura 6-Esquema com a rota da biomassa até o uso da hidrólise enzimática

Fonte: Adaptada TAHERZADEH et al. (30)

\subsection{ARABINOFURANOSIDASES}

\subsubsection{Uso biotecnológico e sua produção}

A ação hidrolítica das enzimas arabinofuranosidases se aplicam para a produção de bioetanol e também para outros diversos produtos de interesse industrial. A indústria de papel e celulose é uma das que utilizam coquetéis enzimáticos para a produção de papel, pelo fato de processar grandes quantidades de biomassa lignocelulósica.(31) A etapa na qual se utiliza muito pectinases, mananases, xilanases e arabinofuranosidases é no branqueamento do papel, etapa na qual ocorre degradação de polissacarídeos ligados a lignina. A vantagem no uso de enzimas para o branqueamento do papel é pelo fato de diminuir o uso de compostos como cloro. (32)O processo de deslignificação da polpa realizado por arabinofuranosidases ocorre pela quebra de uma ligação $\alpha-1,3$ glicosídica entre arabinose e xilose e assim libera uma lignina ligada a um resíduo de arabinose. Além disso, a ação dessas enzimas pode ser sinergística a xilanases que também atuam na remoção de arabinoxilanos na hemicelulose da polpa. (31) 
Recentemente, as $\alpha$-l-arabinofuranosidases são utilizadas para a degradação de lignocelulose para diversos fins, como já descrito na produção de papel e produtos da agroindústria. Muitas vezes o papel da enzima é concedido pelo seu efeito positivo sobre a atividade de outras enzimas que atuam sobre a lignocelulose. Para essa finalidade, estas enzimas são usadas em muitas aplicações biotecnológicas, incluindo a indústria do vinho, a clarificação de sucos de frutas. Outro importante aprimoramento é na digestão de alimentos para animais e atua também na confecção do pão (atrasa seu endurecimento pelo fato de aumentar a disponibilidade de carboidratos solúveis existentes na massa). (33-34)

A fabricação de pães exige uma série de etapas para que a durabilidade do produto seja cada vez mais conservada. Um dos grandes problemas é o endurecimento do pão, que quanto mais tardio melhor é para a indústria. Para que perdas econômicas sejam evitadas, alguns processos biotecnológicos envolvendo enzimas são empregados na fabricação de pães. (35)Os polissacarídeos nãoamiláceos (glucanos, hemicelulose, mananos e pectinas) tem a capacidade de se ligarem a grandes quantidades de água, o que leva a ser um ingrediente fundamental para a produção de pães. Alguns efeitos como: volume e textura do pão são gerados com a adição destes polissacarídeos. Embora os resultados possam diferir dependendo das variedades de trigo, o enriquecimento do pão com arabinoxilano causa maior retenção de água na massa.

O arabinoxilano é adicionado na massa de pão, pois é um polissacarídeo que possui arabinose, uma pentose capaz de se ligar a água e portanto gera um aspecto viscoso para a massa de pão. $(36,95)$ Além disso, um papel nutricional vem sendo atribuído, porque reduzem a absorção de ácidos graxos e colesterol e aumentam a mobilidade gastrointestinal. (37) Como a farinha de trigo possui baixíssima quantidade desses polissacarídeos é necessário a adição dos mesmos com $\alpha$ - amilases, proteases, endo-xilanases e a-arabinofuranosidases. Portanto, 0 combinado de pentoses e enzimas podem contribuir para retardar o endurecimento de pães. (38) As a-l-arabinofuranosidase hidrolizam principalmente, ligações arabinofuranosil externas de polissacarídeos não-amiláceos.(34) 
Graças a sua capacidade de hidrolisar ligações de cadeias laterais existentes em resíduos ricos em arabinose, as arabinofuranosidases são usadas na indústria de sucos. O processo industrial da produção de sucos envolve a quebra de fibras, taninos e pectinas da fruta e resulta em um precipitante que causa turbidez ao suco. Para produção industrial de sucos, são empregados alguns tipos de arabinofuranosidases, com a finalidade de tratamento da polpa (retirada deaçúcares da fruta) e transformar as substâncias pécticas em componentes solúveis.(39) Juntamente com outras enzimas, em um "coquetel pectinolítico", são responsáveis pela remoção de cadeias laterais de ligações $\alpha-1,3$ presentes em cadeias principais de $\alpha-1,5$ de arabinano.

Após a primeira etapa de remoção das cadeias laterais, chamada de hidrólise parcial, é formado um precipitado que causa turbidez ao suco, portanto deve ser feito novo tratamento enzimático para aumentar a viscosidade do suco e retirar os componentes poucos solúveis. Para isso, são empregadas outras arabinofuranosidades e arabinases em quantidades ideais para clarificar ainda mais o produto. (40-41)

A aplicação das arabinofuranosidases se estende também na fabricação de vinhos, pois aumenta o sabor do vinho através de uma melhor aromatização. Denominados como "aromas primários de vinho", conhecidos também por "aromas varietais"; são terpenos livres (isopronóides); presentes no mosto e no vinho em diferentes quantidades de terpenos glicosilados e inodoros. Com a finalidade de melhorar o aroma e sabor do vinho, os isoprenóides são liberados de cadeias de mono ou dissacarídeos. (42)

Para que ocorra essa remoção de torpenos, algumas hidrolase de glicosídeos são empregadas. No caso de dissacarídeos, dependendo da natureza do açúcar na extremidade não redutora, uma $\alpha$-I- arabinofuranosidase, uma $\alpha-1$ ramnosidase, uma $\beta$-d-xilosidase ou uma $\beta$ - $d$ - apiosidase que resultam em resíduos de: arabinose, ramnose, xilose ou apiose, respectivamente. Num segundo passo, a $\beta$-glucosidase hidrolisa a ligação glicosídica restante, libertando um tipo de lipídio isoprenóide chamado de terpeno. (43) 
Existem diversos compostos que são utilizados no vinho para promover um aromatização do mesmo, todos provenientes de glicosídeos de compostos voláteis identificados em plantas e frutas. São chamados de O- $\beta$-d-glicosídeos ou Odiglicosídeos. Em alguns casos, glicoconjugados trissacarídicos foram observados. (44) A porção aglicona está sempre ligada à $\beta$-d-glucopiranose. No caso dos diglicosídeos, como exemplificado na Figura 7 , a porção de glicose foi adicionalmente substituída por um dos seguintes monossacarídeos: $\alpha-\mid-$ arabinofuranose, $\alpha$-l-arabinopiranose, $\alpha$-l-ramnopiranose, $\beta$ - $d$-glucopiranose, $\beta$ - $d$ apiofuranose e $\beta$-d-xilopiranose.

A nomeclatura dos substratos dissacarídicos é estabelecida de acordo com as espécies vegetais das quais eles foram isolados: $6-\mathrm{O}-\alpha-\mathrm{l}-$ arabinopiranosil- $\beta$ - $\mathrm{d}$ glucopiranósidos (vicianosídeos), 6-O- $\alpha$-l-ramnopiranosil- $\beta$-d-glucopiranósidos (rutinosídeos), 6-O- $\beta$ - d-glucopiranosil- $\beta$-d-glucopiranosídeos (gentiobiosides), 6-O$\beta$-d-xilopiranosil- $\beta$-d-glucopiranosídeos (primeverosides) e 6 -O- $\beta$ - $d$-apiofuranosil- $\beta$ d-glucopiranósideos. (42) 


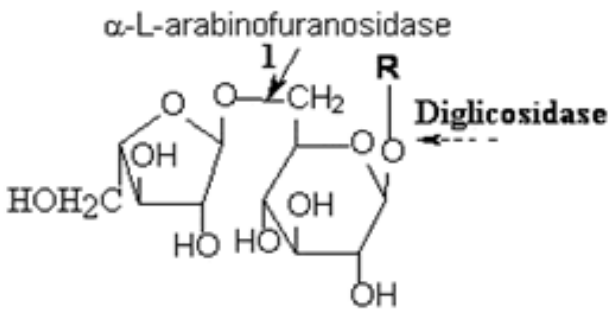

$\alpha$-L-arabinofuranosil- $\beta$-D-glicosideo

$\alpha$-L-rhamnosidase

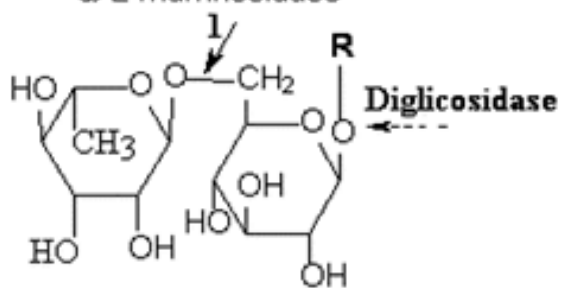

$\alpha$-L-rhamnopiranosil- $\beta$-D-glicosideo

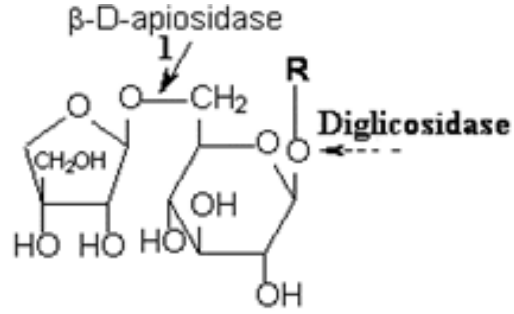

$\beta$-D-apiofuranosil- $\beta$-D-glicosideo

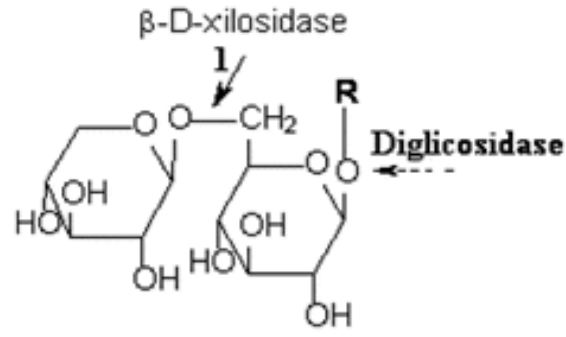

$\beta$-D-xilopiranosil- $\beta$-D-glicosideo

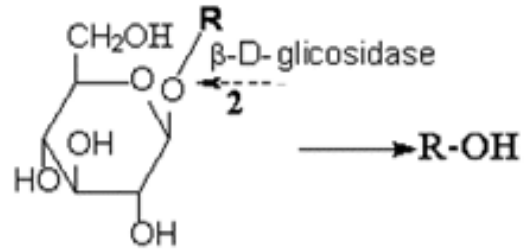

$\mathrm{R}-\mathrm{OH}=$ monoterpenos, norisoprenoides, benzeno derivados

Figura 7 - Esquema representativo das reações formando os aromatizantes de vinho, através da ação de enzimas.

Fonte: Adaptada de SARRY (42) 


\subsubsection{A bioquímica e produção das arabinofuranosidases}

As arabinofuranosidases são classificadas em 3 tipos: as que não podem degradar políssacarídeos, chamadas de tipo $\mathrm{A}$ e correspondem as proteínas da família de hidrolase de glicosídeos 51; as que podem degradar políssacarídeos, chamadas de tipo $B$ agrupadas na família 54 e ainda há aquelas do tipo AXH que degradam especificamente arabinoxilano encontradas nas familias 43 e 62 . As famílias foram agrupadas através da semelhança entre as estruturas primárias e divergem entre si em relação aos substratos, pois muitas vezes enzimas da mesma família,similaridade estrutural que tenham, acabam sendo reativas a substratos variados que nem sempre coincidem totalmente. (45-47)

As enzimas em questão tratam-se basicamente de hidrolases de glicosídeos responsáveis por hidrolisar resíduos não redutores de polissacarídeos que possuem arabinose, como, por exemplo, componentes da hemicelulose (arabinoxilano, xilano, galactomananos, manose e outras pentoses), como mostradoas nas Figura 8 e Figura9.

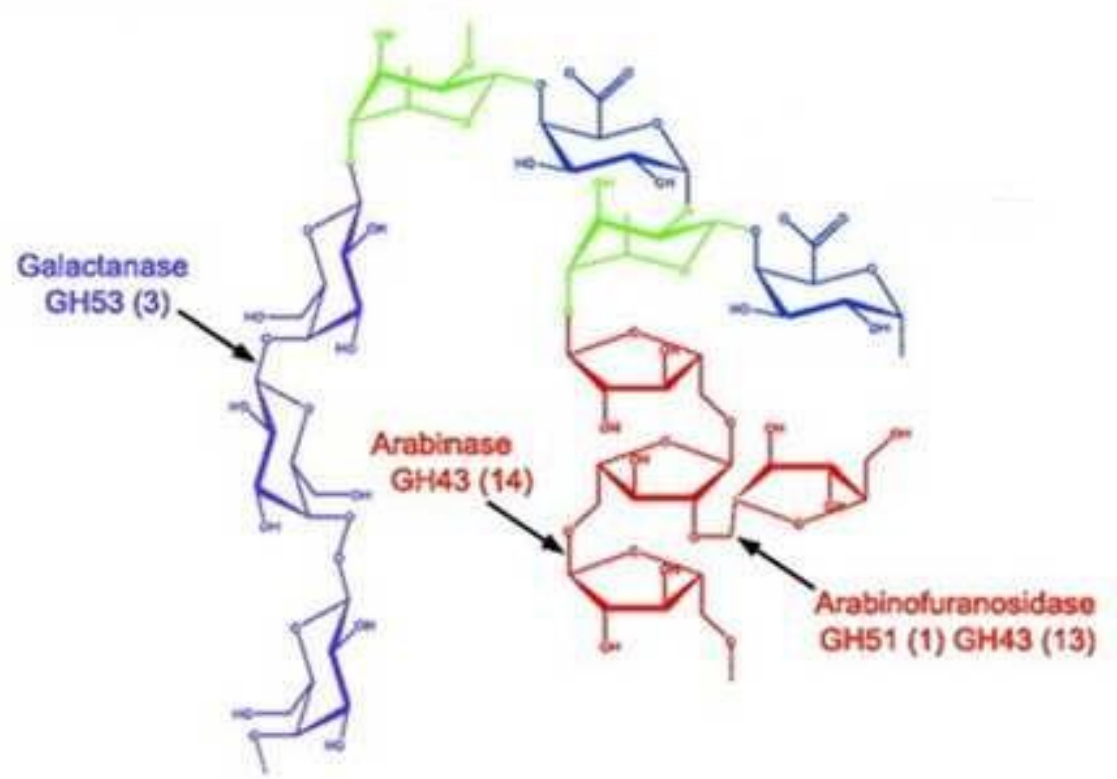

Figura 8-Esquema representando a ação de cada enzima pertencente a famílias de GH51, GH43 Fonte: DEBOY et al. (27) 
Degradação de xilana

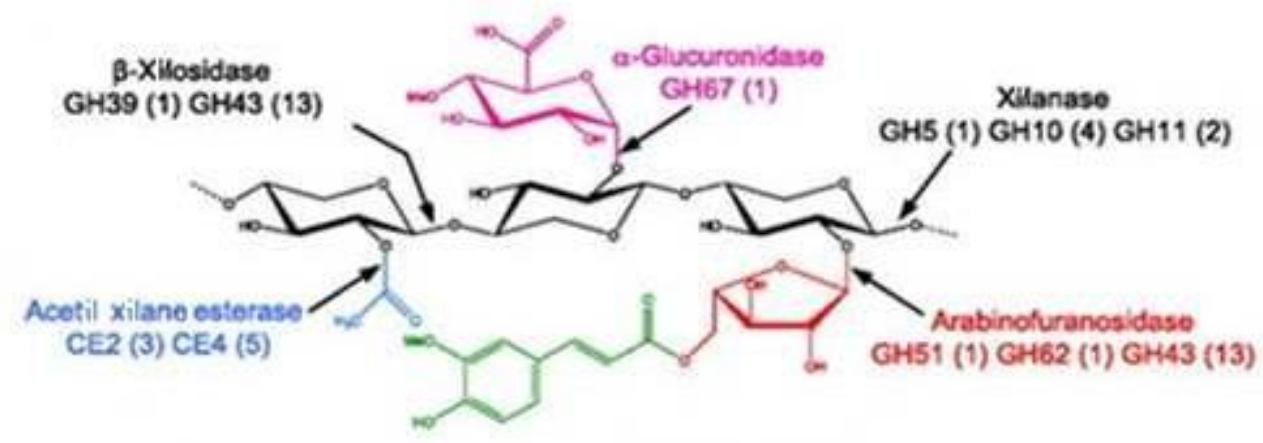

Acetato

alpha-L-Arabinose

Ácido Ferúlico

beta-D-Galactose

alpha-D-Ácido Galaturonico

beta-D-Glicose

alpha-D-Ácido Gluconico

beta-D-Manose

alpha-L-Ramnose

beta-D-Xilose

\section{Degradação de ramnogalacturonana}

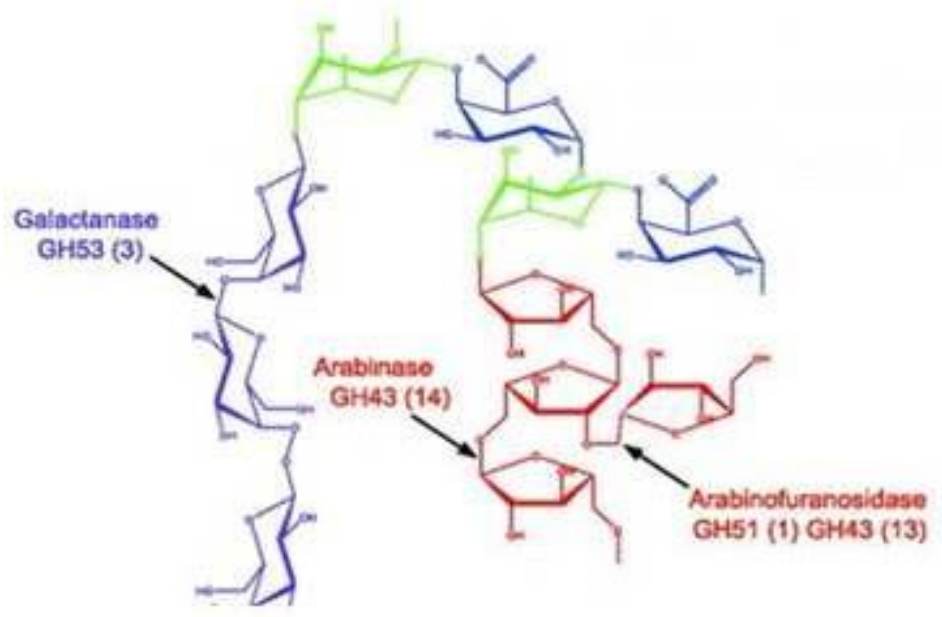

Figura 9-Esquema representando a ação de cada enzima pertencente a famílias de GH51, GH43 e GH62.

Fonte: DEBOY et al. (27) 
O grupo de arabinofuranosidases da família 62 ainda é bastante desconhecido em relação à função, pois como dito anteriormente, são proteínas que variam em relação à especificidade de substratos, além de que poucas estruturas foram determinadas.

Muitos microrganismos possuem potencial produção de arabinofuranosidases, no entanto o que influência a quantidade e a qualidade da expressão dessas enzimas é principalmente a fonte de carbono utilizada no meio de cultura. Por essa razão, os resíduos agrícolas e industriais de biomassa são uma opção vantajosa e ecológica, por terem diversas fontes de carbono capazes de induzir o processo de produção dessas proteínas. (48-49)

Por meio dos avanços biotecnológicos, muitas enzimas estão sendo produzidas isoladamente e depois reunidas em forma de coquetéis para a comercialização industrial. Um exemplo seria o uso de arabinofuranosidases para indústrias alimentícias e de celulose para fins variados, como, por exemplo, para a deslignificação de celulose através das quebras de resíduos arabinanos existentes na polpa de papel. O uso dessas enzimas evita que outros compostos nocivos ao meio ambiente sejam usados, como, por exemplo, hidrocarboneto clorado. Muitas rações para animais vêm sendo suplementadas com arabinofuranosidases para ajudar na composição gástrica, auxiliando na quebra de forragem rica em hemicelulose ingerida pelos animais durante a fase de crescimento.(47,50-51)

Trabalhos também reportam a produção de arabinofuranosidase em frutos e que isso gera mudanças na textura, firmeza e perda de suco. No geral, por ser uma enzima que modifica a parede celular e torna polissacarídeos (como pectinas) de hemicelulose alvos de solubilização e despolimerização, muitos frutos que a produzem em maiores quantidades acabam sofrendo modificações fisiológicas e bioquímicas que influenciam até mesmo na época da colheita.(49)

\subsubsection{Alpha - I - arabinofuranosidase de Thielavia terrestris}

Devido a sua característica de acelerar reações químicas, as enzimas são consideradas biocatalisadores com alto grau de especificidade. A diversidade dessas proteínas é devido à grande variedade de reações químicas que essas catalisam, ou seja, em razão de suas diferentes funções em diversos substratos. $(52,54)$ 
São consideradas enzimas hidrolíticas, por plena definição, aquelas com a capacidade de realizar a reação de hidrólise. As principais hidrolases de interesse agrícola são divididas em: amilases, pectinases, celulases e xilanases. Pela capacidade de degradar substâncias naturais, as enzimas hidroltíicas são de larga utilização industrial, podendo expandir-se nas áreas têxteis, alimentícia, farmacêutica, agrícola e auxilio na produção de biocombustíveis. $(13,53,101)$

A fonte de origem enzimática pode ser de origem vegetal, animal e microbiológica. A obtenção via microrganismos é mais procurada por exigir menores recursos para sua aquisição e perspectivas em sintetizar maiores quantidades de enzima. (54). As diversas formas de cultivar os fungos são usadas para melhorar a produção de determinada enzima. Estratégias de cultivo também devem ser empregadas, como agitação, adição de reagente ou até mudanças de $\mathrm{pH}$, temperatura e fontes de nutriente (como carbono, nitrogênio e fósforo) e até disponibilidade de oxigênio. (55)

O fungo Thielavia terrestris pertence ao filo Ascomycota, o qual se caracteriza pela diversidade (mais de 10.000 espécies catalogadas) e por habitar diferentes locais (habitat variados como solo, vegetais e animais). As formas de assimilação de nutrientes também são diferenciadas, sendo alguns considerados saprófitos (decompõem materiais como madeira, folha e excrementos) e outros até parasitas de plantas, insetos e peixes. A espécie Thielavia terrestris possui cerca de 9.815 genes e é conhecido como um dos mais novos fungos que se destacam em ter uma excepcional poder celulolítico em condição termotolerante. $(56,81)$

De acordo com Gilbert et al., a espécie Thielavia terrestris mostrou resultados mais robustos em altas temperaturas, indicando ser um organismo termoestável.(57) Thielavia terrestris era conhecido como Allescheria terrestris, quando descrito por Apinis em 1963, em solos aluviais na Inglaterra. Suas principais características morfológicas são os ascomas escuros e ascósporos com apenas um poro germinativo. De acordo com Samson e colaboradores, as melhores condições de crescimento para a espécie é em torno de $45^{\circ} \mathrm{C}$, em meio contendo ágar extrato malte (farinha de milho).(58)

Sabe-se que fungos filamentosos como este possui uma produção de enzimas hidroltíicas para materiais lignocelulósicos, a qual é superior a produção de bactérias e leveduras.(59) Além disso, os fungos têm a capacidade de excretar 
outras enzimas que desramificam o complexo lignocelulolítico. (59) Tal complexo é composto por substâncias como xilana, que requer um sistema de enzimas para hidrolisar por completo devido a sua alta heterogeneidade e complexidade. As enzimas que degradam o sistema xilanolítico atuam atacando não apenas a cadeia principal, mas também as ramificações. (60) Para auxiliar na despolimerização de xilana, outras enzimas auxiliares são necessárias para a retirada de resíduos substituintes específicos, sendo essas: B-glucuronidases, B-L-arabinosidases, acetilxilanaesterases e esterases do ácido ferúlico e p-cumárico. (61)

A proteína estudada nesse trabalho pertence a familia 62 composta por $\alpha-L-$ Arabinofuranosidases. Esta possui duas subfamílias distintas que diferem não apenas em quantidade de membros, mas principalmente em características estruturais e funcionais. As GH62-1 possuem 30 membros com apenas 3 membros caracterizados, já as GH62-2 tem cerca de 76 membros dos quais mais de 12 já foram caracterizados.(62) A diferença estrutural notada entre as subfamílias é que, além das GH62-2 ser um grupo mais homogêneo, possui uma estrutura de loop mais curta que as $\mathrm{GH} 62-1 .(63,84)$ 


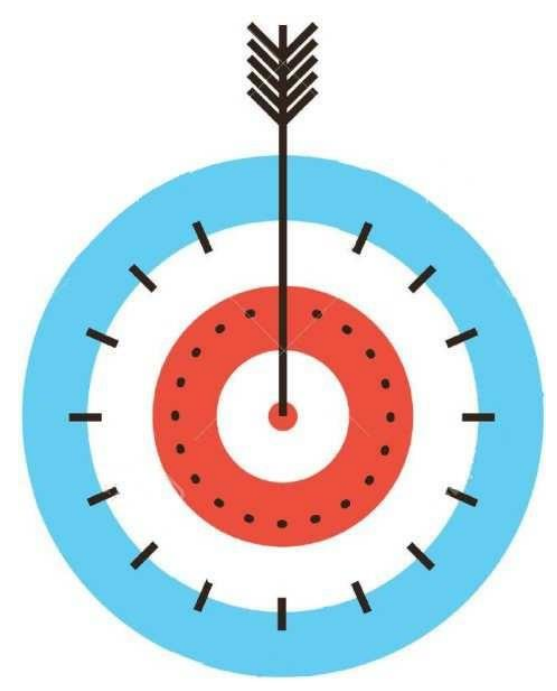

\section{OBJETIVOS}

\subsection{OBJETIVOS GERAIS}

O projeto busca a caracterização funcional e estrutural de uma enzima arabinofuranosidase da família GH62, como parte de um estudo para verificar a eficiência da mesma na decomposição do bagaço de cana-de-açúcar.

\subsection{OBJETIVOS ESPECÍFICOS}

1. Clonagem e expressão heteróloga em Escherichia coli.

2. Purificação da proteína através de cromatografia líquida.

3. Resolução da estrutura molecular da enzima através da cristalização e análise de dados da difração de raios $X$.

4. Estudos funcionais da proteína a partir de ensaios de atividade enzimática e fluorimetria diferencial de varredura (DSF).

5. Estudos funcionais da proteína relativo a sua atividade enzimática.

6. Produção de mutantes para a comprovação do sítio ativo e da estrutura molecular da enzima. 


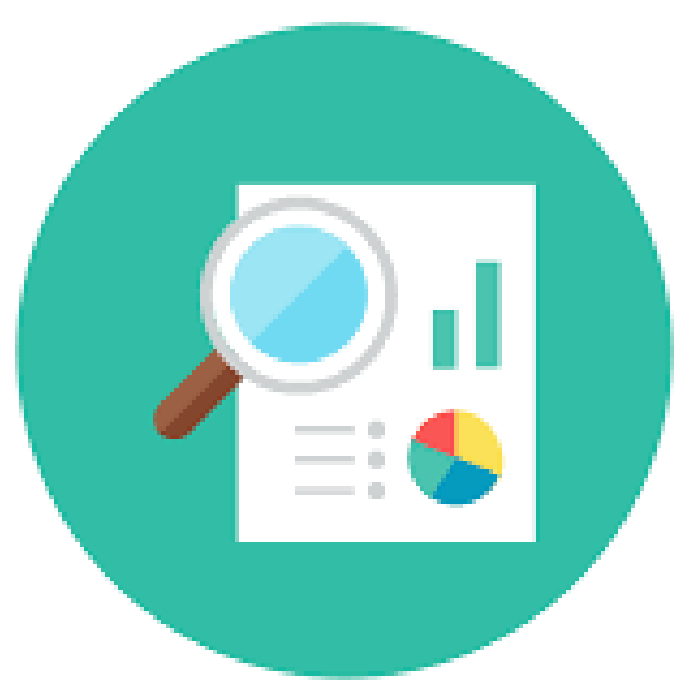

\section{MATERIAIS E MÉTODOS}

\subsection{MICRORGANISMO E CULTIVO}

A linhagem T. terrestris ATCC 38088 foi obtida da American Type CultureCollection. $\mathrm{O}$ cultivo foi realizado em meio líquido modificado pela adição de glutamina e tiamina com composição de $2 \%$ de glicose, 5 mM de glutamina, 2,4 $\mathrm{mM}$ de tiamina, mais $50 \mathrm{~mL}$ de sais Clutterbuck 20 vezes concentrado (em $1 \mathrm{~L}$ de água MilliQ: $120 \mathrm{~g}$ de $\mathrm{NaNO}, 10,4 \mathrm{~g}$ de $\mathrm{KCl}, 10,4 \mathrm{~g}$ de $\mathrm{MgSO} 4,30,4 \mathrm{~g}$ de $\mathrm{KH}_{2} \mathrm{PO}_{4}$ ) e $1 \mathrm{~mL}$ de uma solução de traços de metais por litro (em $100 \mathrm{~mL}$ de água MilliQ:2,2 $\mathrm{g} \mathrm{ZnSO}$, $1 \mathrm{~g}$ de $\mathrm{H}_{3} \mathrm{BO}_{3}, 0,5 \mathrm{~g}$ de $\mathrm{MnCl}_{2} .4 \mathrm{H}_{2} \mathrm{O}, 0,5 \mathrm{~g}$ de $\mathrm{FeSO}_{4} .7 \mathrm{H}_{2} \mathrm{O}, 0,16 \mathrm{~g}$ de $\mathrm{CoCl}_{2} .5 \mathrm{H}_{2} \mathrm{O}, 0,16 \mathrm{~g}$ de $\mathrm{CuSO}_{4} .5 \mathrm{H}_{2} \mathrm{O}, 0,11 \mathrm{~g}$ de $\mathrm{Na}_{2} \mathrm{MoO}_{4} \cdot 4 \mathrm{H}_{2} \mathrm{O}$ e $5 \mathrm{~g}$ de Na 2 EDTA em pH 6,5), sob agitação (150 rpm) a $45^{\circ} \mathrm{C}$ por 48 horas.

\subsection{EXTRAÇÃO DO DNA DE THIELAVIA TERRESTRIS}

Uma fração de $10 \mathrm{~g}$ de micélio de fungo de $\mathrm{T}$. terrestris foi colocada em nitrogênio líquido e, em seguida, moída mais facilmente com a ajuda de um pistilo. 
Após a moagem, foi colocado em tubo de $1,5 \mathrm{~mL}$ onde foram adicionados $600 \mu \mathrm{L}$ de solução de extração do genoma, aquecida a $68{ }^{\circ} \mathrm{C}$ durante 10 minutos. A amostra foi centrifugada a $13.000 \times$ g durante 5 minutos à temperatura ambiente. $O$ sobrenadante foi transferido para um novo tubo. Foram adicionados $40 \mu \mathrm{L}$ de ácido acético 100\% $5 \mathrm{M}$, depois deixados em gelo durante 10 minutos. Centrifugou novamente a $13.000 \mathrm{xg}$ durante 5 minutos à temperatura ambiente, repetindo o procedimento com o sobrenadante. Cerca de $2,5 \times$ o volume de etanol a $96 \%$ foi centrifugado a $13.000 \mathrm{xg}$ durante 5 minutos novamente $\mathrm{e}$ descartou 0 sobrenadante. Lavou-se duas vezes com etanol a $70 \%$, centrifugou-se novamente, após a secagem adicionou-se $40 \mu \mathrm{L}$ de TE e $50 \mu \mathrm{L}$ de RNAse. Para confirmar a pureza e qualidade do DNA extraído, a amostra foi analisada em gel de agarose usando a técnica de eletroforese em gel de agarose $0,8 \%$.

\subsection{CLONAGEM, TRANSFORMAÇÃO E EXPRESSÃO HETERÓLOGA}

A proteína foi expressa usando o sistema de expressão em Escherichia coli. O vetor de expressão usado neste trabalho é o vetor LIC, que tem a vantagem de fazer a inserção do vetor sem uso de enzimas de restrição ou ligação $(96,97)$. O gene que codifica a $\alpha$-L-arabinofuranosidase foi amplificado a partir de DNA de Thielavia terrestris por PCR e clonado em um vetor pET-Trx de expressão LIC, todos as condições de reação do PCR estão descritas na Tabela 1 e os oligonucleotídeos estão listados na Figura 10.

A primeira etapa da clonagem foi o tratamento do vetor através de linearização utilizando enzima Bsal (NEB) seguido de tratamento com T4 DNA polymerase (NEB) para que o vetor adquirisse terminações complementares, de acordo com o protocolo de Helmholtz Zentrum München.(97) Após tratamento do vetor, foi feita a preparação do fragmento gênico através de amplificação com oligonucleotídeos. A reação de amplificação continha $5 \mu$ de tampão 10X Pfu DNA polymerase (NEB), $0,5 \mu \mathrm{l}$ de forward e $0,5 \mu \mathrm{l}$ de reverse, $2 \mu \mathrm{l}$ de dNTP, $0.5 \mu \mathrm{l}$ de DNA de Thielavia terrestris e 2,5 unidades de $P f u$ DNA polymerase (NEB). Ao final da reação, completavasse com água MilliQ até totalizar $50 \mu \mathrm{l}$ de reação. Após a amplificação, o produto da reação de PCR anterior foi tratado com T4 DNA polymerase (NEB) de acordo com o protocolo de Helmholtz Zentrum München.(97) 
A última etapa da clonagem foi a hibridização entre 0 fragmento gênico e o vetor, ambos com as extremidades livres e coesivas para que assim se complementassem. A reação foi entre $2 \mu \mathrm{l}$ de fragmento gênico tratado com $T 4$ DNA polymerase e $1 \mu \mathrm{l}$ de vetor tratado com T4 DNA polymerase com a adição de $1 \mu$ de EDTA 25 mM. A reação foi incubada a $25 \stackrel{\circ}{\circ}$ por 30 minutos.

A proteína pode ser produzida por uma célula bacteriana. $\mathrm{Na}$ expressão, a arabinofuranosidase permanece dentro da célula bacteriana contida no meio de cultura juntamente com outras proteínas. A transformação quimiocompetente foi feita utilizando células $\mathrm{DH} 10 \mathrm{~B}$ como linhagem de propagação. Uma alíquota de bactérias ultracompetentes foram descongeladas em gelo e adicionou-se $20 \mu \mathrm{L}$ do plasmídeo em $80 \mu \mathrm{L}$ de tampão de transformação (1 mL KCM 10x - $1 \mathrm{M}$ de KCl, 0,3 $\mathrm{M} \mathrm{CaCl}_{2}, 0,5 \mathrm{M} \mathrm{MgCl}_{2} ; 1,5 \mathrm{~mL}$ PEG $10 \% 4000 \mathrm{~m} / \mathrm{L}$; $7,5 \mathrm{~mL}$ água mili-Q autoclavada). A mistura foi mantida em gelo por 30 minutos, em seguida manteve-se em temperatura ambiente por 10 minutos. Para finalizar o processo, foi adicionado $1 \mathrm{~mL}$ de meio de cultura Luria-Bertani (LB $-10 \mathrm{~g} / \mathrm{L}$ de Triptona; $5 \mathrm{~g} / \mathrm{L}$ de extrato de levedura e $10 \mathrm{~g} / \mathrm{L}$ de $\mathrm{NaCl}$ ) e incubou-se por 50 minutos a $37 \stackrel{\circ}{ } \mathrm{C}$. Usando uma alça de Drigalski, espalhou-se a solução em placa de petri contendo meio LB com ágar, e os antibióticos cloranfenicol a $35 \mu \mathrm{g} / \mathrm{mL}$ e canamicina a $50 \mu \mathrm{g} / \mathrm{mL}$.

Tabela 1 - Condições da reação de PCR utilizadas no protocolo de clonagem LIC (Ligase Independent Cloning). (97)

\begin{tabular}{|l|c|c|c|}
\hline Etapa & Temperatura & Tempo & Ciclos \\
\hline 1 - Desnaturação & $95{ }^{\circ} \mathrm{C}$ & 3 minutos & 1 ciclo \\
\hline 2 - Desnaturação_ & $95{ }^{\circ} \mathrm{C} C$ & 45 segundos & \\
\hline 3 - Hibridização & $83{ }^{\circ} \mathrm{C}$ & 30 segundos & 30 ciclos \\
\hline 4 - Extenção cíclica & $68 \stackrel{\circ}{\mathrm{C}}$ & 10 minutos & \\
\hline 5 - Extenção final & $68 \stackrel{\circ}{\mathrm{C}}$ & 6 minutos & 1 ciclo \\
\hdashline 6 - Interrupção da & $4 \stackrel{\circ}{\mathrm{C}}$ & 3 minutos & 1 ciclo \\
reação & & \\
Fonte: Elaborado pela autora.
\end{tabular}


Após o crescimento das colônias bacterianas, concluiu-se que a clonagem foi de fato efetiva e assim pode-se continuar a produção dos clones passando para a linhagem de expressão Rosetta-gami тм 2(DE3) através do protocolo de eletroporação. Para retirar os plasmídeos de interesse, foi usado o kit comercial PureYield ${ }^{\mathrm{TM}}$ Plasmid MiniPrep System (PROMEGA®) seguindo o protocolo estabelecido pelo fabricante.

Com o DNA purificado, misturou se $1 \mu \mathrm{L}$ de DNA a uma alíquota de célula $(50 \mu \mathrm{L})$ em uma cubeta gelada transferida para a câmara do eletroporador GenePulser XCel/® (Bio-Rad Laboratories, Hercules, EUA). Os parâmetros usados no pulso da eletroporação foram capacitância de $25 \mu \mathrm{F}$; resistor de $400 \mathrm{~m} \Omega$ e carga de $1,8 \mathrm{kV}$. Removeu-se a cubeta e a suspensão celular foi transferida para um tubo de $1,5 \mathrm{~mL}$ contendo meio LB. Incubou-se a solução celular a $37^{\circ} \mathrm{C}$ por 1 hora. Em seguida, repetiu-se o processo de cultivo em placa de petri usando meio LB com ágar e os devidos antibióticos. As células de E. coli transformadas com o clone de expressão foram cultivadas em $1 \mathrm{~L}$ de meio de autoindução $\left(3,3 \mathrm{~g} / \mathrm{L}\right.$ de $\left(\mathrm{NH}_{4}\right)_{2} \mathrm{SO}_{4}$; 6,8 $\mathrm{g} / \mathrm{L}$ de $\mathrm{KH}_{2} \mathrm{PO}_{4} ; 7,1 \mathrm{~g} / \mathrm{L}$ de $\mathrm{Na}_{2} \mathrm{HPO}_{4} ; 5 \mathrm{~g} / \mathrm{L}$ de glicerol; $0,5 \mathrm{~g} / \mathrm{L}$ de glicose; $2 \mathrm{~g} / \mathrm{L}$ de lactose; $10 \mathrm{~g} / \mathrm{L}$ de triptona; $5 \mathrm{~g} / \mathrm{L}$ de extrato de levedura), suplementado com canamicina e clorofenicol nas concentrações citadas anteriormente, com agitação de $500 \mathrm{rpm}$ a $37{ }^{\circ} \mathrm{C}$ até uma D.O 600 de 0,6; após atingir a densidade óptica, abaixou-se a temperatura para $17 \stackrel{\circ}{\circ} \mathrm{C}$, mantendo a temperatura para induzir a expressão da proteína durante $15 \mathrm{~h}$. A indução é feita através da lactose contida no meio de expressão, para que o promotor $T 7$ seja ativado e assim iniciar o processo de transcrição. O sucesso da expressão foi confirmado por gel de poliacrilamida 15\% SDS-PAGE corado com Comassie Blue e descorado com solução de ácido acético $10 \%$. As células foram separadas por centrifugação a 3.000 rpm durante 20 min a $4{ }^{\circ} \mathrm{C}$ e o precipitado celular armazenado a $-80^{\circ} \mathrm{C}$ até o uso. 


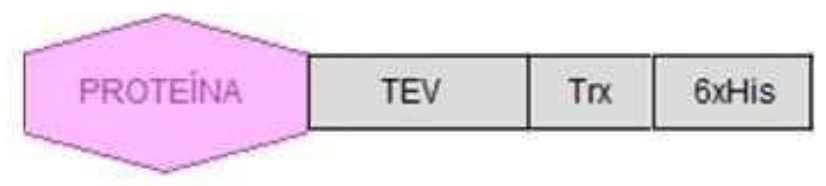

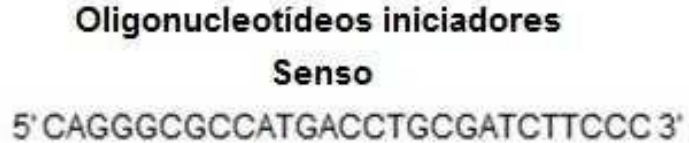

Anti-senso
Temperatura de Melting

$83,4^{\circ} \mathrm{C}$

$83,1^{\circ} \mathrm{C}$

3' GACCCGACGCGGTTAGCGCTGCAGAGTG 5'

\section{$83,10 \mathrm{C}$}

Figura 10 -Primers e esquema representativo do clone.

Fonte: Elaborada pela autora

\subsection{TRATAMENTO DO PELLETCELULAR E PURIFICAÇÃO POR CROMATOGRAFIA}

O precipitado celular foi ressuspenso em tampão A ( $\mathrm{NaCl} 250 \mathrm{mM}$, Tris$\mathrm{HCl} 50 \mathrm{mM}$, glicerol a $10 \%(\mathrm{p} / \mathrm{v}), \mathrm{pH} 7,5)$ para separar o sedimento celular. O pellet foi tratado em 3 ciclos de sonicação no gelo (30 segundos de sonicação, 30 segundos de descanso), com um sonicador Fisher Scientific ${ }^{\text {TM Modelo }} 505$ Sonic Dismembrator ajustado com $45 \%$ de amplitude. Em seguida, o lisado foi centrifugado a $13.000 \mathrm{rpm}$ a $4{ }^{\circ} \mathrm{C}$ durante 40 minutos.

A primeira purificação por cromatografia de afinidade com $2 \mathrm{~mL}$ de resina de níquel (GE Healthcare Life Sciences Ni Sepharose 6 Fast Flow), após lavagem da coluna com $20 \mathrm{VC}$ (volume de coluna) de água mili-Q, equilibrou-se a coluna passando $10 \mathrm{VC}$ de tampão A. Para começar o processo de eluição, usou-se frações de 5 VC de tampão $A$ com crescentes concentrações de imidazol $(10 \mathrm{mM}$, $50 \mathrm{mM}, 100 \mathrm{mM}, 150 \mathrm{mM}, 200 \mathrm{mM}$ e $350 \mathrm{mM}$ respectivamente). A proteína foi eluída com tampão $A$ contendo $150 \mathrm{mM}$ de imidazol e a coluna foi lavada com tampão A contendo $500 \mathrm{mM}$ de imidazol. A proteína passou por uma diálise overnight a $4{ }^{\circ} \mathrm{C}$ com tampão $\mathrm{A}$ sem imidazol, para depois adicionar TEV (Tobacco Etch Vírus) protease para clivagem da proteína de fus na região $\mathrm{N}$-terminal. A TEV foi adicionada na fração de $1 \mathrm{mg}$ para cada $50 \mathrm{mg}$ de proteína. 
Antes da segunda purificação, foi necessário passar a amostra novamente na coluna de resina de níquel para que a proteína de fusão ficasse retida na coluna e eluisse apenas a amostra contendo a proteína de interesse. Essa etapa foi feita eluindo a proteína com $20 \mathrm{~mL}$ de tampão A sem imidazol.

$\mathrm{Na}$ segunda purificação usou-se cromatografia de filtração em gel por exclusão de tamanho molecular. A coluna utilizada foi HiLoad 16/60 Superdex 200 (GE Healthcare) com tampão de corrida $\mathrm{B}$ ( $\mathrm{NaCl} 150 \mathrm{mM}$, Tris-HCl $50 \mathrm{mM}$, glicerol a $10 \%(\mathrm{p} / \mathrm{v}), \mathrm{pH} 7,5)$. Todo o processo foi feito utilizando o equipamento cromatógrafo Äkta Purifier (Pharmacia Biotec/GE, EUA) com total volume de coluna e fluxo de $0,5 \mathrm{~mL} / \mathrm{min}$ de tampão e monitoramento a $280 \mathrm{~nm}$ de absorbância em UV. A pureza da proteína foi confirmada por gel de poliacrilamida 15\% SDS-PAGE.

\subsection{GEL NATIVO}

A técnica de SDS-PAGE é o método mais frequentemente utilizado para a detecção e confirmação de proteínas. No entanto, tal método não serve para experimentos em que deseja se seja descobrir o estado oligomérico de uma proteína ou comportamento da proteína com base na sua atividade biológica. Isso é impedido pelo fato da proteína ser totalmente desnaturada na análise por SDSPAGE. O gel nativo é feito em condições não-desnaturantes, portanto, demonstra o comportamento da enzima em seu estado ativo (Figura 11). O gel utilizado é de poliacrilamida (em geral na porcentagem de $7,5 \%$ ), sem SDS para que não desnature a amostra.

O experimento consiste em manter as proteínas em condições nas quais a carga líquida distinta no $\mathrm{pH}$ do gel (7-8), permitindo que as amostras sejam separadas pelas suas mobilidades eletroforéticas no gel. 


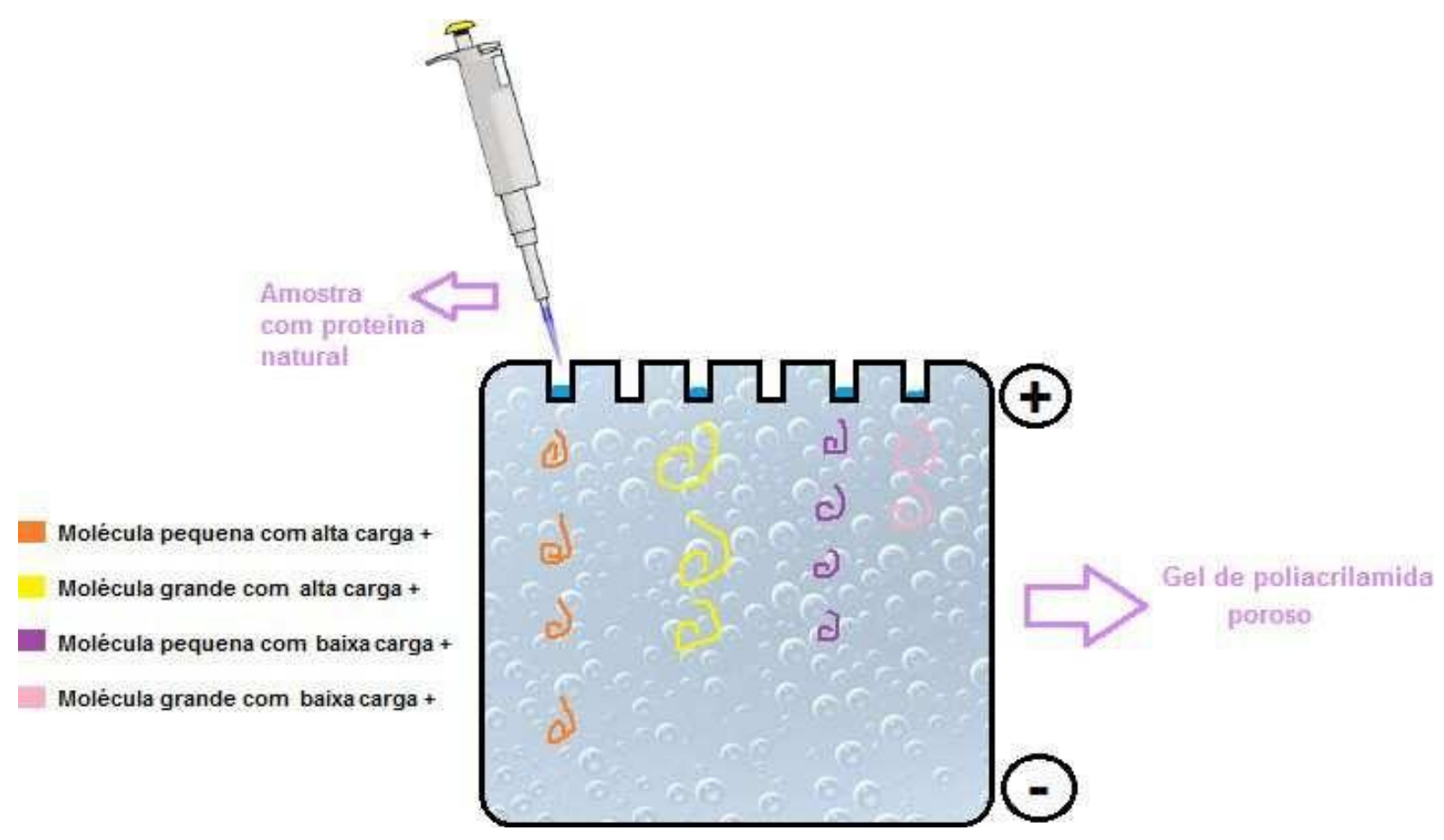

Figura 11 - Imagem representativa da técnica de Gel Nativo, que proteínas pequenas são menos conservadas pelas fibras do gel em comparação à proteínas maiores. Portanto as proteínas menores migram mais rapidamente.

Fonte: Elaborada pela autora.

Utilizou-se o equipamento Phast System (Amersham Biosciences) e um gel com ausência de SDS, com gradiente de 8 a 25\% de acrilamida (GE). Para visualizar o resultado, o gel foi corado com Comassie Blue com metanol $25 \%$ e ácido acético 10\% e descorado com solução aquosa de ácido acético 10\%.

\subsection{ENSAIOS DE CRISTALZAÇÃO E COLETA DE DADOS DE DIFRAÇÃO DE RAIOS X}

O processo de cristalização de macromoléculas é complexo e ainda não é completamente compreendido. Ao decorrer dos anos, técnicas empíricas vêm sendo adotadas para tornar o processo mais bem protocolado. Alguns cuidados devem ser tomados para a garantia de formação de cristais de qualidade, ou seja, difratáveis. Um exemplo disso seria a utilização de amostras de proteínas mais puras possíveis. O crescimento do cristal começa com uma solução supersaturada de macromoléculas, evoluindo para um estado termodinâmico estável no qual a proteína é dividida entre 2 estados: fase sólida e solúvel. Portanto, o processo de 
cristalização pode ser classificado em duas etapas, sendo a primeira a fase de nucleação e depois crescimento do cristal. Ou seja, ocorre uma fase de crescimento dos cristais e nucleação, ambas longe de atingir o equilibrio, o qual só é atingido com a separação do sólido da solução. Para se obter a condição de supersaturação é necessário a adição de agentes precipitantes e/ou modificando algum parâmetro interno da solução (temperatura, pH) como exemplificado no esquema Figura 12. $(64,65)$

O método de gota assentada para a cristalização da proteína representa um dos processo de difusão de vapor. Uma amostra purificada de proteína e precipitante são colocados de forma que tenham que se equilibrar com um reservatório maior contendo condições semelhantes em uma maior concentração, sendo assim, à medida que a água vaporiza, ela se transfere do meio de menor concentração (gota), para o reservatório de maior concentração (poço). Assim que a pressão de vapor se equilibra, a concentração de precipitante atinge um nível ideal para a cristalização da macromolécula. $(64,66)$

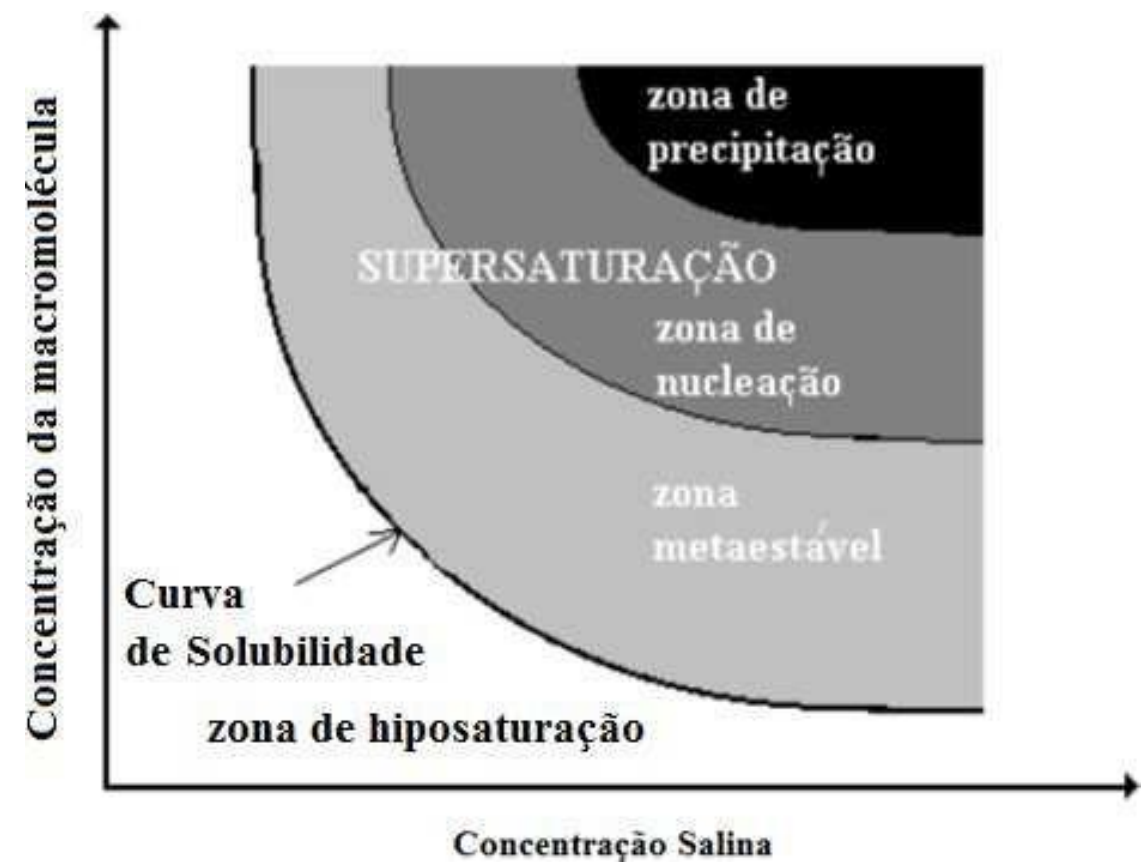

Figura 12 - Diagrama de fases da solução de proteína em função da concentração e agentes precipitantes.

Fonte: Adaptada de GIACOVAZZO et al.(64) 
Os cristais da Arabinofuranosidase de T. terrestris foram obtidos a uma concentração de $20 \mathrm{mg} / \mathrm{mL}$ de proteína purificada com tampão A previamente descrita e todas as concentrações de proteínas foram determinadas pelo espectrofotômetro NanoDrop 2000 (Thermo Scientific). Um pré-teste de cristalização foi empregado a fim de verificar a concentração ideal para formação de cristais, usando a proteína a $10 \mathrm{mg} / \mathrm{mL}$ e $20 \mathrm{mg} / \mathrm{mL}$. O kit utilizado foi РСT тм Pre-Crystallization Test (HAMPTON Research) e o protocolo seguido foi de acordo com o manual do fabricante (67). O rastreio inicial das condições de cristalização foi realizado em 5 kits sendo que cada um deles explora 96 condições diferentes, ao todo foram feitas mais de 500 condições de cristalização, usando um robô de cristalização The Crystal Gryphon LCP (Art Robbins Instruments) que utiliza a técnica de sitting drop com concentrações de solução proteica e solução de poço nas seguintes razões: 0,5:1, 1:2 e 2:1. Os cristais foram obtidos em um mês durante a exposição a uma solução de reservatório cuja composição foi de: acetato de sódio $0,1 \mathrm{M}(\mathrm{pH} 4,6)$ e sulfato de amônio $2 \mathrm{M}$ a $18{ }^{\circ} \mathrm{C}$. O cristal foi resfriado diretamente em nitrogênio líquido em cryoloops e dados de difração foram coletados usando radiação sincrotron no Laboratório Nacional de Luz Sincrotron LNLS, Campinas, Brasil. Os dados foram coletados na linha de luz W01B-MX2 usando um detector Pilatus 2M (Dectris). Os dados foram indexados e integrados usando o programa MOSFLM (70) ou XDS e escalados usando AIMLESS do pacote de programas CCP4. (70)

\subsection{DETERMINAÇÃO E REFINAMENTO DA ESTRUTURA}

A estrutura da enzima foi resolvida usando a substituição molecular com auxlio do programa Phaser (94). O método de substituição molecular se baseia em sobreposição de estruturas entre proteínas da mesma família, pois espera se que proteínas da mesma familia tenham um enovelamento similar. A estrutura da $\alpha-L-$ arabinofuranosidase de Streptomyces coelicolor em complexo com arabinose (PDB ID 3WMY), foi usado como modelo de busca, possuindo $74 \%$ de identidade sequencial. Para o refinamento cristalográfico foi realizado utilizando PHENIX $(71,72)$ e REFMAC5 $(73)$ e a construção do modelo foi realizada com o programa COOT (74) usando mapas de densidade de elétrons 2Fo-Fc e Fo-Fc. 
Moléculas de solvente, como água, íns de sulfato e moléculas de etileno glicol foram adicionadas apropriadamente, também utilizando-se o COOT. O comportamento de $\mathrm{R}$ e Rfree foi utilizado como critério principal para validar o protocolo de refinamento e sua convergência. A qualidade estereoquímica do modelo foi avaliada com MoIProbity (75). O programa PISA (74) foi aplicado para verificar os estados de oligômeros avaliando interfaces e sua força de interação entre monômeros vizinhos gerados pela aplicação de simetria ao arquivo de coordenadas atômicas da estrutura cristalográfica da GH62 de Thielavia terrestris, consequentemente, preveem a forma biológica mais provável da estrutura.

\subsection{FLUORIMETRIA DIFERENCIAL DE VARREDURA (DSF)}

Para avaliar o comportamento da enzima sob diferentes condições, utiliza-se o método de fluorimetria diferencial de varredura (do inglês: Differential scanning fluorimetry). O aparelho CFX96 Real-Time System (Bio-Rad) é possível detectar a fluorescência em função da temperatura e obter o Tm (temperatura de melting na qual ocorre a mudança de enovelamento da proteína). O ensaio consiste em aplicar em placa de PCR (parede fina com 96 poços e fita de vedação de qualidade óptica) $30 \mu \mathrm{g}$ de arabinofuranosidase de $\mathrm{T}$. terrestris com soluções tamponantes diversas atingindo uma concentração final de $50 \mathrm{mM}$ e adição de 1:2000 da sonda fluorescente SYPRO Orange diluída em tampão fosfato de sódio $50 \mathrm{mM}$ (Molecular Probes). O SYPRO Orange se liga a porção hidrofóbica da proteína, portanto na forma desnaturada da proteína. Conforme ocorre a desnaturação da proteína a sonda se liga à amostra e assim emitindo a fluorescencia, a qual é detectada pelo equipamento. A tabela com os tampões utilizados será apresentada em Materiais Suplementares. As análises das amostras ocorreram em entre $25{ }^{\circ} \mathrm{C}$ a $90{ }^{\circ} \mathrm{C}$ e para se estabelecer uma estabilidade, para cada variação de

1 ำ, utilizou-se um período de incubação de 30 segundos. A variação da fluorescência da SYPRO Orange foi medida usando excitação em 490 nm e emissão em $530 \mathrm{~nm}$. A construção e análise das curvas, incluindo a determinação da temperatura de fusão $(\mathrm{Tm})$ de cada amostra, foram realizadas usando o software GraphPAd Prism (versão 5.0). 


\subsection{ENSAIOS DE ATIVIDADE ENZIMÁTICA - PAINEL DE SUBSTRATOS, CURVA DE ATVIDADE EM DIFERENTES PH'S E CURVA DE ATIVIDADE EM DIFERENTES TEMPERATURAS}

A atividade enzimática em diferentes substratos foi medida usando $1 \%(\mathrm{p} / \mathrm{v})$ dos substratos arabinoxilano de trigo (baixa viscosidade), arabinoxilano de trigo (alta viscosidade), arabinano linear, arabinogalactano, xilano, xiloglucano, carboximetilcelulose, manano, beta glucano (baixa viscosidade), High purity Lichenan Icelandic Moss (Megazyme) e $5 \mathrm{mM}$ de pNP-a-l-arabinofuranósido. A proteína foi colocada em tampão Mcilvaine em pH 4,5 (exceto em ensaio de atividade em diferentes $\mathrm{pH}$ 's) e incubada usando como temperatura padrão $50^{\circ} \mathrm{C}$ (exceto para ensaio de atividade em diferentes temperaturas).A liberação de $\rho$ nitrofenol foi determinada em $400 \mathrm{~nm}$, portanto fez se a leitura a essa absorbância usando espectrofotômetro TECAN SpectraFluor Multifunction Fluorescence.

Uma unidade $(U)$ de $\alpha$-l-arabinofuranosidase foi definida como a quantidade de enzima capaz de liberar $1 \mu \mathrm{mol}$ do produto por minuto de reação sob as condições específicas do ensaio. A liberação de açúcares redutores foi determinada pelo método DNS (ácido 3,5-dinitrosalićlico). Foi retirado $10 \mu \mathrm{L}$ de cada amostra para realizar a leitura. A reação foi feita utilizando ThermoMixer (Eppendorf) a 300 rpm por 20 minutos cada reação, com uma concentação de enzima próxima a $10 \mathrm{Ug}$. A reação foi interrompida com $100 \mu \mathrm{l} \mathrm{de}$ Tetraburato de Sódio supersaturado.

A atividade enzimática em diferentes temperaturas e pH's foi medida pelo método colorimétrico, utilizando pNP-a-l-arabinofuranósido e Arabinoxilano de trigo como substratos e os açúcares redutores determinados de acordo com o procedimento de Miller. (90)A reação constituída por $50 \mu \mathrm{l}$ de substrato em tampãoMcilvaine (1\% p / v), $40 \mu \mathrm{l}$ de tampão Mcilvaine a 50 mM, pH 4,5 e $10 \mu \mathrm{l}$ de solução enzimática (numa concentração de $0,1 \mu \mathrm{g} / \mu \mathrm{l}$ ), foi incubada em ThermoMixer (Eppendorf) á $50^{\circ} \mathrm{C}$ durante 20 minutos. Para determinar o $\mathrm{pH}$ e temperatura ótimos, a reação enzimática foi realizada em diferentes valores de $\mathrm{pH}$ em tampão Mcilvaine 50 mM, pH 2,0 a 10,0 e após utilização do pH ótimo em faixa de temperatura de $5^{\circ} \mathrm{C}$ a $65^{\circ} \mathrm{C}$. As constantes avaliadas foram: velocidade máxima (Vmax), constante de Michaelis-Menten (Km), constante catalítica (Kcat) e eficiência catalítica (Kcat / Km). As constantes cinéticas TtGH62 foram 
determinadas usando pNP-a Arabinoxilano de trigo $(0,1-10 \mathrm{mg} / \mathrm{ml}$ ) como substrato em $\mathrm{pH}$ e temperatura enzimáticos ideais. $\mathrm{O}$ teor de proteína foi medido usando NanoDrop 2000 (Thermo Scientific).

Os substratos utilizados foram arabinoxilano de trigo variando a concentração até $20 \mathrm{mg} / \mathrm{mL}$ e pNP-aAraF até $40 \mathrm{mg} / \mathrm{mL}$. Foram feitos gráficos que demonstram as curvas de Michaelis-Menten, as quais são fundamentais para definir outros

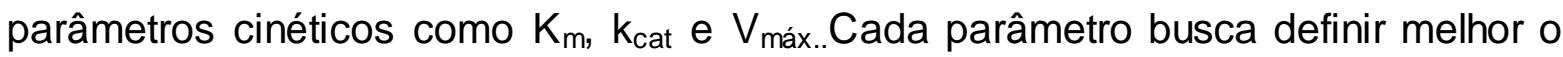
desempenho enzimático durante a reação de hidrólise, a $V_{\text {máx }}$ define 0 valor máximo de velocidade inicial quando todos os sítios catalíticos estão associados a seus respectivos substratos. Já o $\mathrm{k}_{\text {cat }}$ seria a quantidade em mols de substrato aptos a ser transformado em produto a cada mol de enzima por unidade de tempo, chamado também de turnover number. Uma constante importante para o cálculo do $\mathrm{k}_{\mathrm{cat}}$ é o $\mathrm{E}_{\mathrm{t}}$, o qual significa a quantidade de enzima usada no experimento. $O \mathrm{k}_{\mathrm{cat}}$ é calculado a partir da seguinte fórmula:

$$
\mathrm{K}_{\mathrm{cat}}=\frac{\mathrm{V}_{\max }}{\mathrm{E}_{\mathrm{t}}}(1)
$$

A partir dos dados obtidos nos gráficos de Michaelis-Menten foi possível calcular o valor de $\mathrm{K}_{\mathrm{m}}$, $\mathrm{k}_{\text {cat }}$ e $\mathrm{V}_{\text {máx }}$ através do programa Origing (OriginLab). $O \mathrm{~K}_{\mathrm{m}}$ é um parâmetro muito utilizado em ensaios enzimáticos pelo fato de representar a concentração de substrato quando se tem metade da velocidade máxima atingido, como exemplificado abaixo (Figura 13):

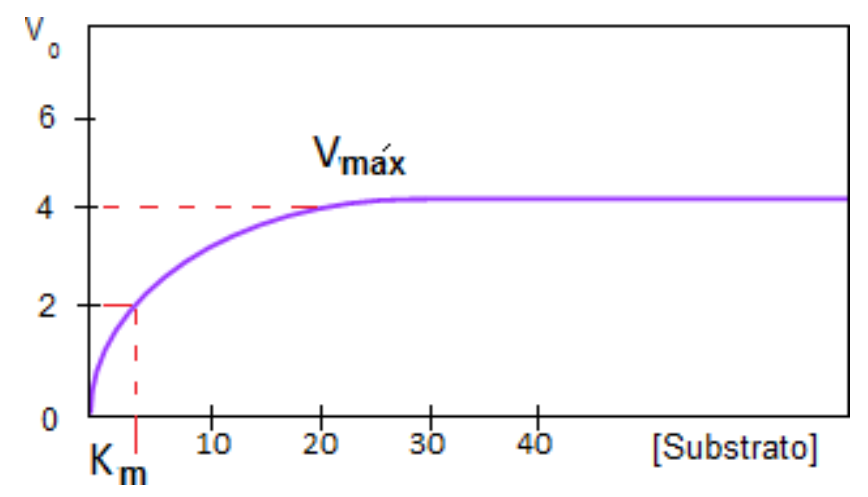

Figura 13 - Gráfico explicativo sobre parâmetros cinéticos $K_{m}$ e $V_{\max }$. Fonte: Elaborada pela autora. 


\subsubsection{Mutações Sítio Dirigidas}

Para complementar a caracterização estrutural e funcional, foi proposto a elaboração de mutantes. Os mutantes seriam para comprovar a relação de aminoácidos do sítio ativo e a importância da ponte dissulfeto para a estrutura como um todo. Todos os clones foram produzidos com a supervisão do Professor Dr. Rolf A. Prade na Oklahoma State University, o qual gentilmente forneceu todos os equipamentos e reagentes necessários para as clonagens e expressão.

- $\quad$ Planejamento dos primers:

Os primers foram desenhados de acordo com o Método de Mutagênese proposto por Kunkel. (77) Os oligonucleotíleos foward e reverse devem conter, cada um, 20 $\mathrm{pb}$ aproximadamente e que se pareiam entre si no plasmídeo, permitindo uma amplificação em sentidos contrários (Figura 14).

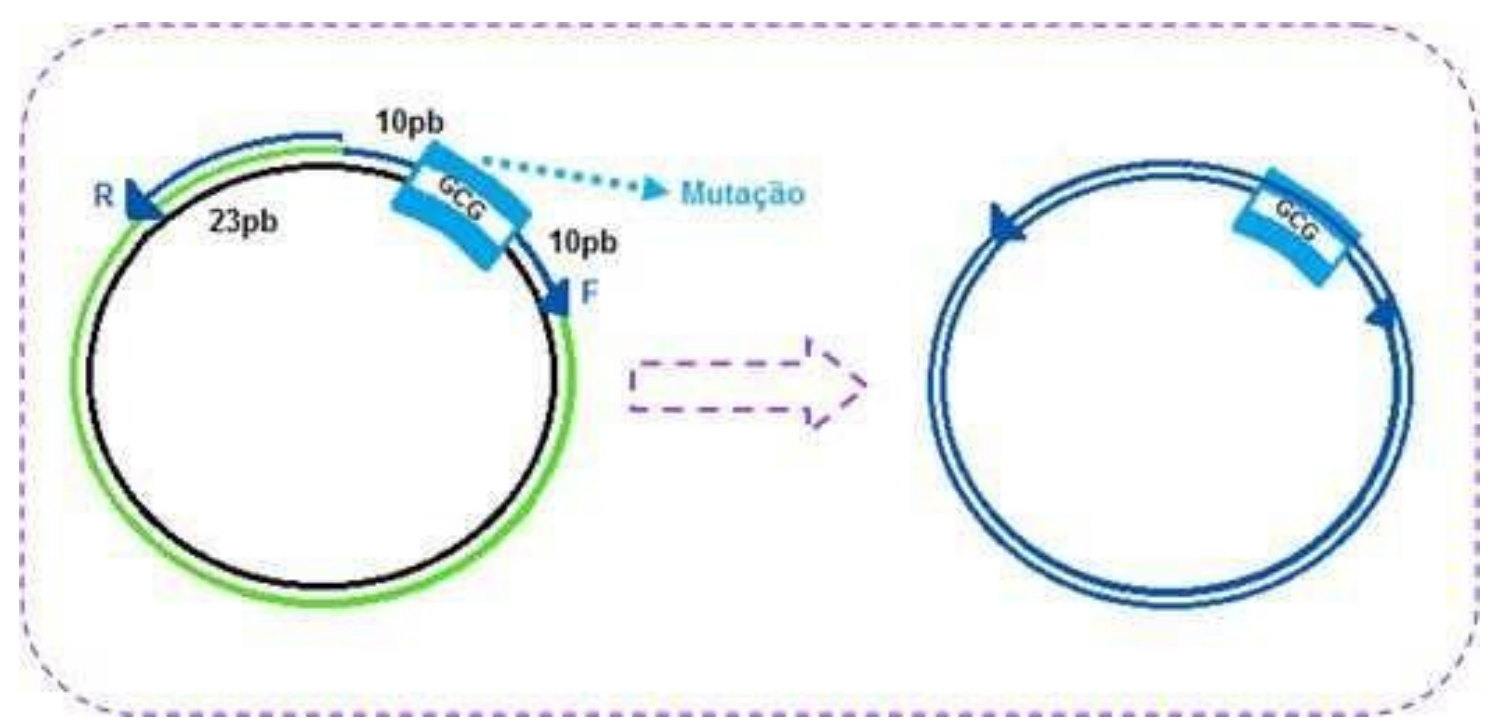

Figura 14 - Esquema representativo do desenho dos oligonucleotídeos. F representa o foward contendo $10 \mathrm{pb}$ antes e 10pb depois da mutação. $\mathrm{R}$ representa o reverse, contendo 23pb complementares antes do início do foward.

Fonte: Elaborada pela autora.

Os primers foram desenhados de acordo com o protocolo de Mutagênese de Kunkel (77). Antes de dar início ao protocolo de clonagem, é importante ressaltar que os primers devem ser fosforilados no grupo de hidroxila 5', para permitir a ligação após a amplificação. Para a confirmação do tamanho do vetor, foi feita uma 
reação de PCR para clivar o vetor. Foi feito um mix de reação contendo $2 \mu \mathrm{L}$ de DNA contido na solução estoque, $1 \mu \mathrm{L}$ de Tampão 3 contendo $\mathrm{NaCl} 100 \mathrm{mM}$, Tris $\mathrm{HCl} 50 \mathrm{mM}, \mathrm{MgCl}_{2} 10 \mathrm{mM}, 1 \mathrm{mM}$ DTT em pH 7 (NEB), $1 \mu \mathrm{L}$ de enzima EcorV (NEB) e $6 \mu \mathrm{L}$ de água autoclavada. Após a reação foi feito um gel de agarose $0,8 \%$ para a eletroforese. As condições da reação anterior estão descritas na Tabela 2.

Tabela 2 - Condições da reação de PCR no processo de produção dos clones

\begin{tabular}{|c|c|c|c|}
\hline Etapa & Temperatura & Tempo & Ciclos \\
\hline 1. & $955_{-}^{\circ} \mathrm{C}$ & 2 minutos & \\
\hline 2 & $95^{\circ} \mathrm{C}$ & 20 segundos & \\
\hline 3 & $66 \stackrel{\circ}{C} \mathrm{C}$ & 10 segundos & 30 ciclos \\
\hline 4 & $72^{\circ} \mathrm{C}$ & 2 minutos & \\
\hline
\end{tabular}

Após a confirmação do tamanho do vetor selvagem, iniciou-se a clonagem fazendo um mix de primers e vetor. Colocou-se $61 \mu \mathrm{L}$ de água autoclavada, $20 \mu \mathrm{L}$ de tampão CG contendo solução de $\mathrm{MgCl}_{2}$ e DMSO (NEB), $4 \mu \mathrm{L}$ de Dntp, $4 \mu \mathrm{L}$ de DMSO, $1 \mu \mathrm{L}$ de $\mathrm{Mg}_{2} \mathrm{Cl}, 1 \mu \mathrm{L}$ de Phusion High-Fidelity DNA Polymerase (NEB), $1 \mu \mathrm{L}$ de DNA do vetor, $1 \mu \mathrm{L}$ de foward e $1 \mu \mathrm{L}$ de reverse. Após a reação, foi confirmado o tamanho do vetor em gel de agarose $0,8 \%$ depois da eletroforese. As bandas foram localizadas e a partir do gel e o resultado da reação de PCR através do kit The Wizard® Genomi DNA Purification (PROMEGA) seguindo as especificações do fabricante e a partir do DNA purificado foi realizada uma segunda etapa de reação: $30 \mu \mathrm{L}$ de DNA, $3 \mu \mathrm{L}$ de tampão 10xLB (NEB) e $1 \mu \mathrm{L}$ de T4 Polynucleotide Kinase (NEB). A reação de fosforilação dos primers foi concluída depois de 30 minutos em $37 \stackrel{\circ}{\mathrm{C}}$ e em seguida 15 minutos a $68 \stackrel{\circ}{\circ} \mathrm{C}$. O resultado da mutação possui uma mistura de espécies de DNA, havendo tanto o DNA selvagem como o mutado. A fita de DNA parental possui grupos metil e para retirar o DNA metilado, é feito um tratamento com Dpnl (NEB). Foi colocado a $37^{\circ} \mathrm{C}$ por 1 hora cerca de $3 \mu \mathrm{L}$ de Dpnl e depois 20 minutos a $68^{\circ} \mathrm{C}$. Após a digestão com Dpnl foi realizado a reação com ligase: $4 \mu \mathrm{L}$ de ATP e $1 \mu \mathrm{L}$ Ligase (NEB) a temperatura ambiente por 10 minutos. 


\subsubsection{Preparação de Células Competentes e Transformação}

A transformação por choque térmico foi feita a partir de células competentes tratadas com cloreto de cálcio. As bactérias contidas em um estoque foram inoculadas em $5 \mathrm{~mL}$ de meio líquido LB e incubadas em estufa à $37^{\circ} \mathrm{C}$ overnight sob $150 \mathrm{rpm}$. Transferiu-se $0,5 \mathrm{~mL}$ do inóculo para um erlenmeyer contendo 250 $\mathrm{mL}$ de meio líquido LB sem antibiótico. Foi mantido em $37^{\circ} \mathrm{C}$ e $150 \mathrm{rpm}$ até que a DO $0,6 \mathrm{~nm}$ chegasse. $\mathrm{O}$ meio foi centrifugado a $3700 \mathrm{rpm}, 4{ }^{\circ} \mathrm{C}$ por 10 minutos e o sobrenadante eliminado. $O$ sedimento foi ressuspenso em $10 \mathrm{~mL}$ de tampão $0,1 \mathrm{M}$ de $\mathrm{MgCl}_{2}$. A amostra foi incubada no gelo por 90 minutos e novamente centrifugada como anteriormente. Após a centrifugação, as células foram ressuspensas em 10 $\mathrm{mL}$ de tampão $0,1 \mathrm{M}$ de $\mathrm{CaCl}_{2} \mathrm{e} 5 \%$ glicerol, aliquotadas em $100 \mathrm{em} 100 \mu \mathrm{L}$ e estocadas à $-80^{\circ} \mathrm{C}$.

Para dar início a transformação, alíquotas de células competentes foram descongeladas em gelo, e $50 \mu \mathrm{L}$ de células com $1 \mu \mathrm{L}$ de DNA foram incubados em gelo por 30 minutos. O choque térmico foi feito a $42{ }^{\circ} \mathrm{C}$ por 30 segundos, sem agitação e rapidamente colocado em gelo por 5 minutos. Retirou-se $950 \mu \mathrm{L}$ de meio S.O.C (Thermo Fisher Scientific) e colocou-se no mix anterior, sob agitação de $250 \mathrm{rpm}$ a $37 \stackrel{\circ}{\mathrm{C}}$ por 60 minutos. Após o processo, a cultura foi centrifugada a $5000 \mathrm{rpm}$ e o pellet celular inoculado em placa de petri contendo meio LB com ágar, e o antibiótico canamicina a $50 \mu \mathrm{g} / \mathrm{mL}$.

Após o crescimento das colônias em meio seletivo, foi confirmado que havia a presença do plasmídeo mutante. Repetiu-se o protocolo de transformação utilizando uma linhagem de E.coli Rosetta ${ }^{T M}$. O clone foi produzido com duas marcas de seletividade e foi inoculado novamente na presença de antibióticos cloranfenicol a $35 \mu \mathrm{g} / \mathrm{mL}$ e canamicina a $50 \mu \mathrm{g} / \mathrm{mL}$.

Foi feito PCR de colônia para verificar as colônias positivas. Utilizando tubo de $1,5 \mathrm{~mL}$ foi feito um mix de $100 \mu \mathrm{L}$ de tampão CG (NEB), $20 \mu \mathrm{L}$ de Dntp, 20 $\mu \mathrm{L}$ de DMSO, $5 \mu \mathrm{L}$ de $\mathrm{Mg}_{2} \mathrm{Cl}, 5 \mu \mathrm{L}$ de Phusion High-Fidelity DNA Polymerase (NEB), $1 \mu \mathrm{L}$ de DNA do vetor, $1 \mu \mathrm{L}$ de foward e $1 \mu \mathrm{L}$ de reverse. Para a confirmação das colônias positivas foi feito um gel de agarose $0,8 \%$ e utilizado a técnica de eletroforese. 


\subsubsection{Expressão, purificação e teste de atividade enzimática}

O teste de expressão foi feito de acordo com o descrito anteriormente, utilizando mesmo meio e mesmas condições de expressão. No entanto, por se tratar de 4 clones, foi feita uma expressão em menor escala, cerca de $250 \mathrm{~mL}$. A confirmação da expressão da proteína foi feita em gel de poliacrilamida 15\% SDSPAGE após eletroforese. A purificação também foi feita de acordo com o descrito anteriormente, utilizando mesmas colunas de cromatografia e mesmos reagentes. O teste de atividade enzimática foi feito a partir de um mix contendo tampão Mcllvaine (ácido cítrico e hidrogenofosfato dissódico) e substrato pNP-aAraF a 2 mM. Incubou-se o mix a $50 \stackrel{\circ}{\circ}$ no ThermoMixer (Eppendorf) por 10 minutos, para então adicionar a enzima $(1 \mathrm{mg} / \mathrm{mL})$. A reação com a enzima foi mantida por 10 minutos e foi utilizado Tetraburato de Sódio supersaturado para parar a reação. A leitura da amostra foi feita em aparelho espectofotométrico TECAN SpectraFluor Multifunction Fluorescence em absorbância de 400 nm. 


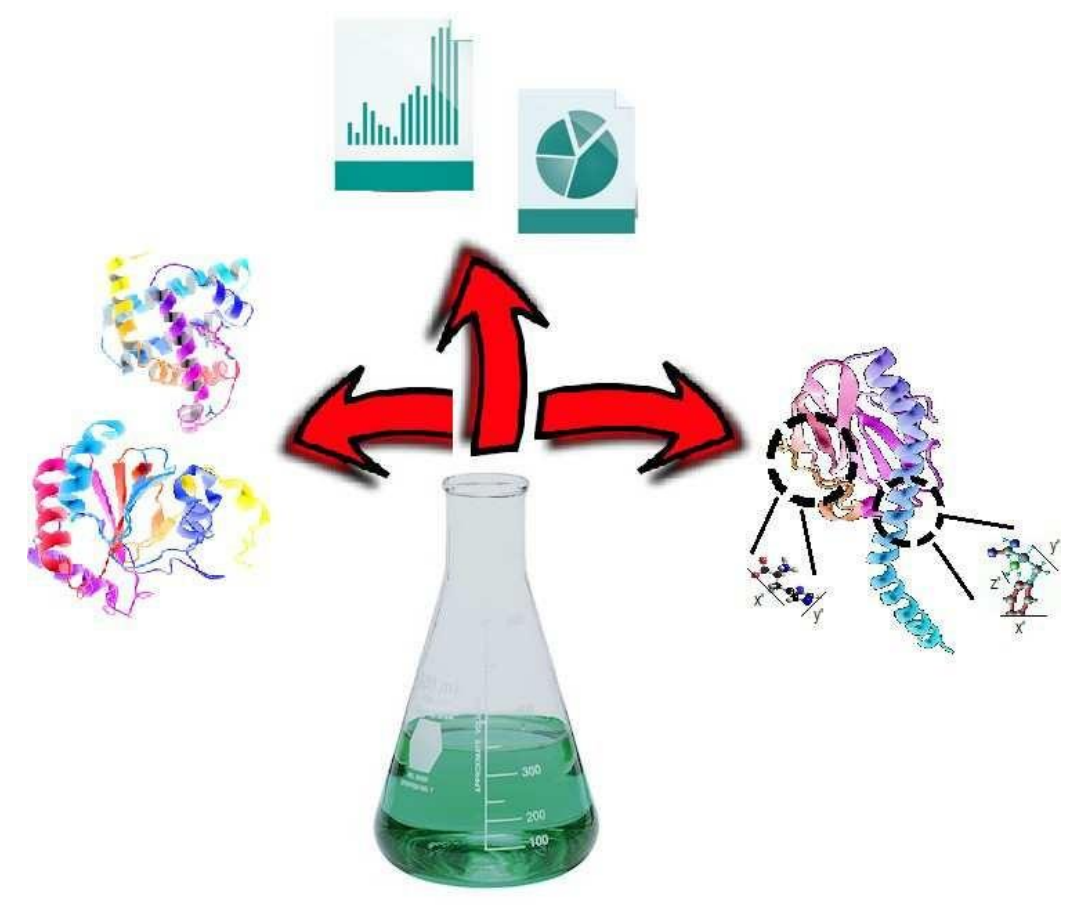

\section{RESULTADOS}

\subsection{CLONAGEM, TRANSFORMAÇÃO, PURIFICAÇÃO, ESTADO OLIGOMÉRICO E DSF}

A extração do DNA fúngico de T.terrestris foi realizada mais de uma vez devido à qualidade do DNA extraído não ser boa o suficiente para usar como template. Foram feitas 7 amostras, como representado na Figura 15. A amostra representada na coluna "E" na Figura 15 foi a de melhor qualidade e, a partir dessa, foi feita a clonagem. A clonagem no vetor LIC como já mencionada, é conhecida pela facilidade no desenvolvimento do protocolo e a ausencia de enzimas de restrição. A linearização do vetor inclui digestão com Bsal, pois o plasmídeo possui dois sítios de Bsal embutidos ao gene da eGFP que, ao ser removido, deixa livre duas extremidades que serão tratadas com T4 polimerase para assim se hibridizar ao 
fragmento gênico. Portanto, como resultado obteve se uma banda correspondente a massa molecular do gene da eGFP ( $\cong 750 \mathrm{pb}$ ) (80) como obtido na Figura 16 .

Após o tratamento das extremidades do vetor e do fragmento gênico, obteve se a hibridização de ambos para, assim, construir o clone desejado, demonstrado na Figura 17.

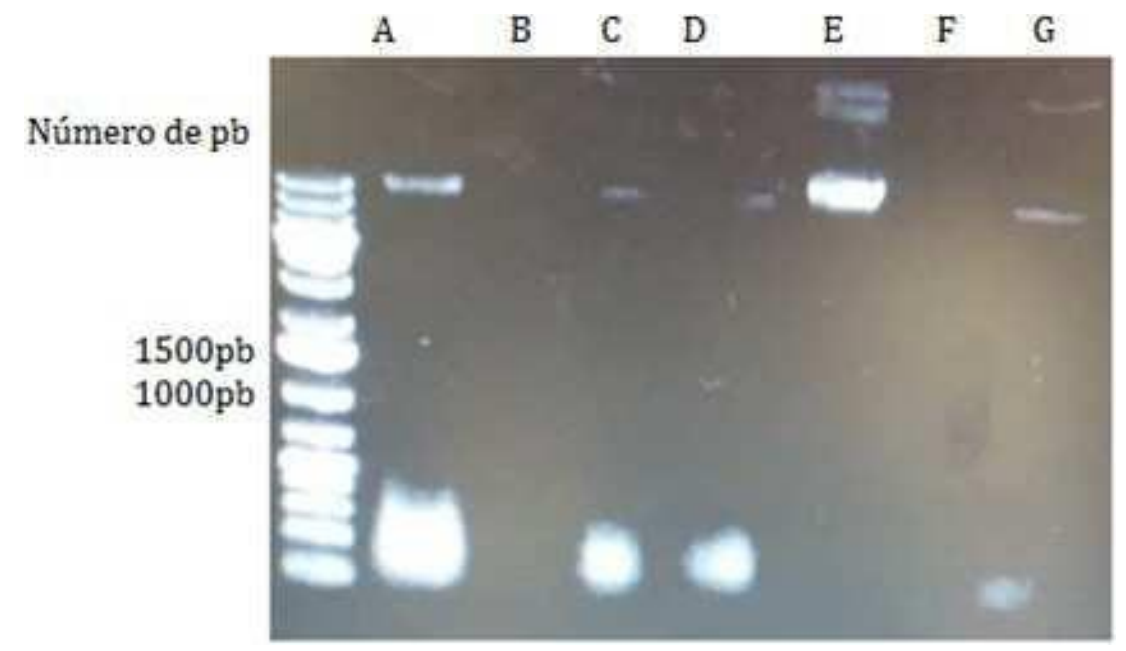

Figura 15 - Eletroforese em gel de agarose 1\%. Primeiro poço representa marcador de massa molecular GeneRuler (1 kb plus ladder plus Life Technologies). A, B, C, D, E, F e G representam as amostras de DNA de Thielavia terrestris após a extração a partir dos micélios do fungo.

Fonte: Elaborada pela autora. 


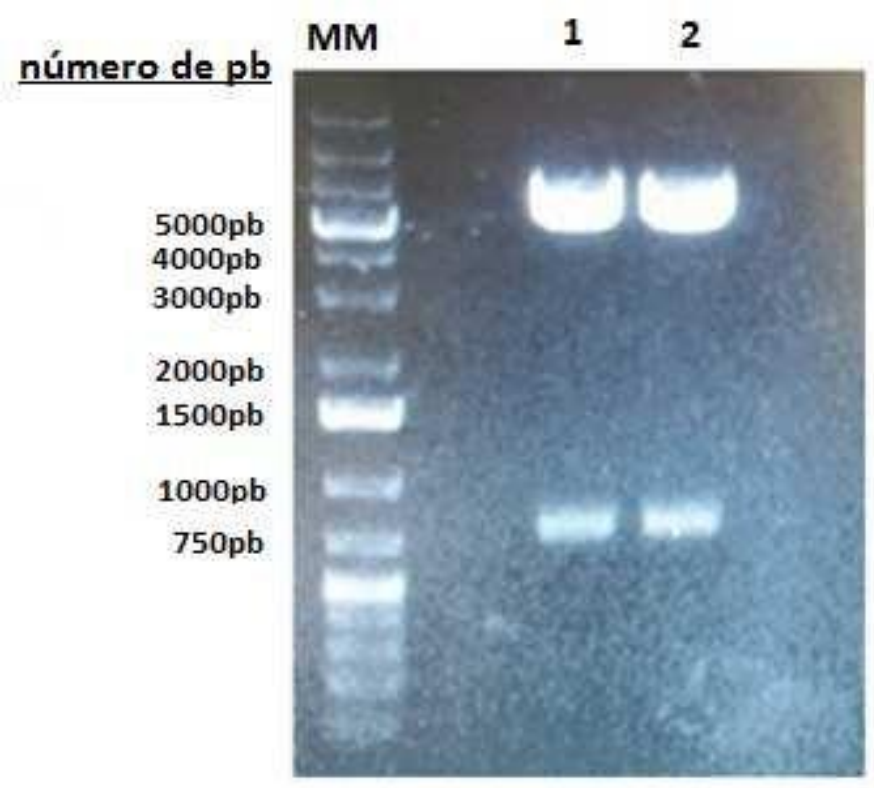

Figura 16 - Eletroforese de gel de agarose $1 \%$ representando o vetor linearizado acima da banda de $1500 \mathrm{pb}$ e o gene da eGFP na banda de $750 \mathrm{pb}$ em 1 e 2. A amostra foi dividida em dois poços, pois havia grande quantidade de DNA.

Fonte: Elaborado pela própria autora.

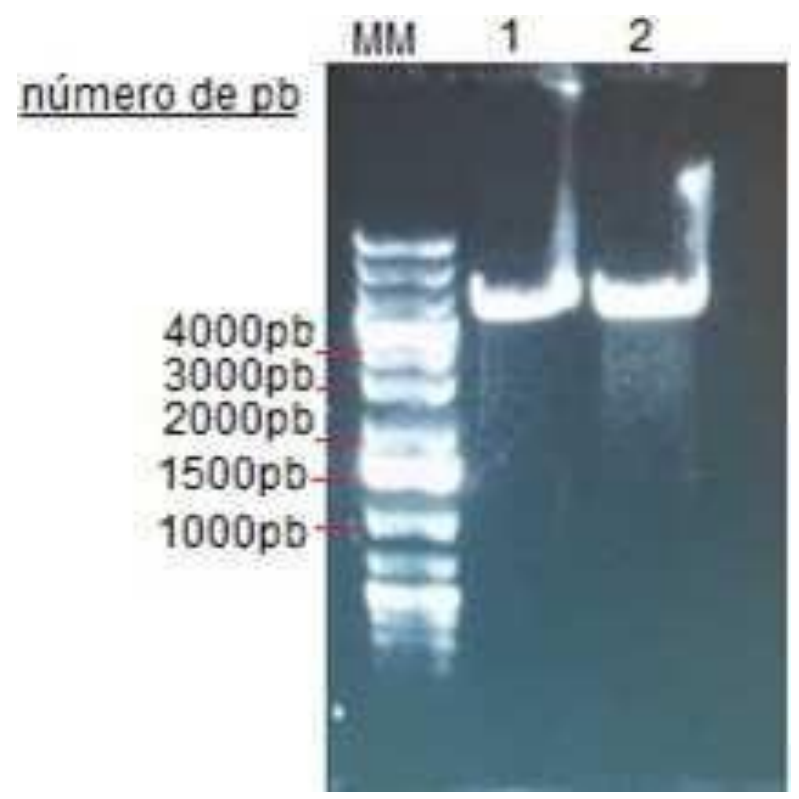

Figura 17-Eletroforese de gel de agarose $1 \%$ representando o resultado da reação de PCR referente a hibridização do vetor ao fragmento gênico, com aproximadamente $6.500 \mathrm{pb}$, em 1 e 2.

Fonte: Elaborada pela autora. 
Após as etapas de clonagem, foi feita a transformação em Origami ${ }^{\mathrm{TM} D E 3 .}$ Tal cepa hospedeira foi usada por apresentar mutações nos genes da tiorrexinaredutase (trxB) e glutationa redutase (gor), o que garante uma adequada formação de ligações dissulfeto no citoplasma de E. coli. Após a transformação, foram feitos testes de expressão e o melhor método para a produção da arabinofuranosidase de $T$. terrestris foi utilizando o meio autoindução em duas temperaturas $\left(38^{\circ}{ }^{\circ} \mathrm{C}\right.$ e 17 $\left.{ }^{\circ} \mathrm{C}\right)$. Os géis que comprovam a expressão da proteína estão demonstrados pela Figura 18, na qual há evidente banda em aproximadamente $45 \mathrm{kDa}$. A proteína possui peso de $31 \mathrm{kDa}$, no entanto, a proteina de fusão contribui com cerca de 14 $\mathrm{kDa}$, resultando em uma massa molecular aparente de cerca de $45 \mathrm{kDa}$.

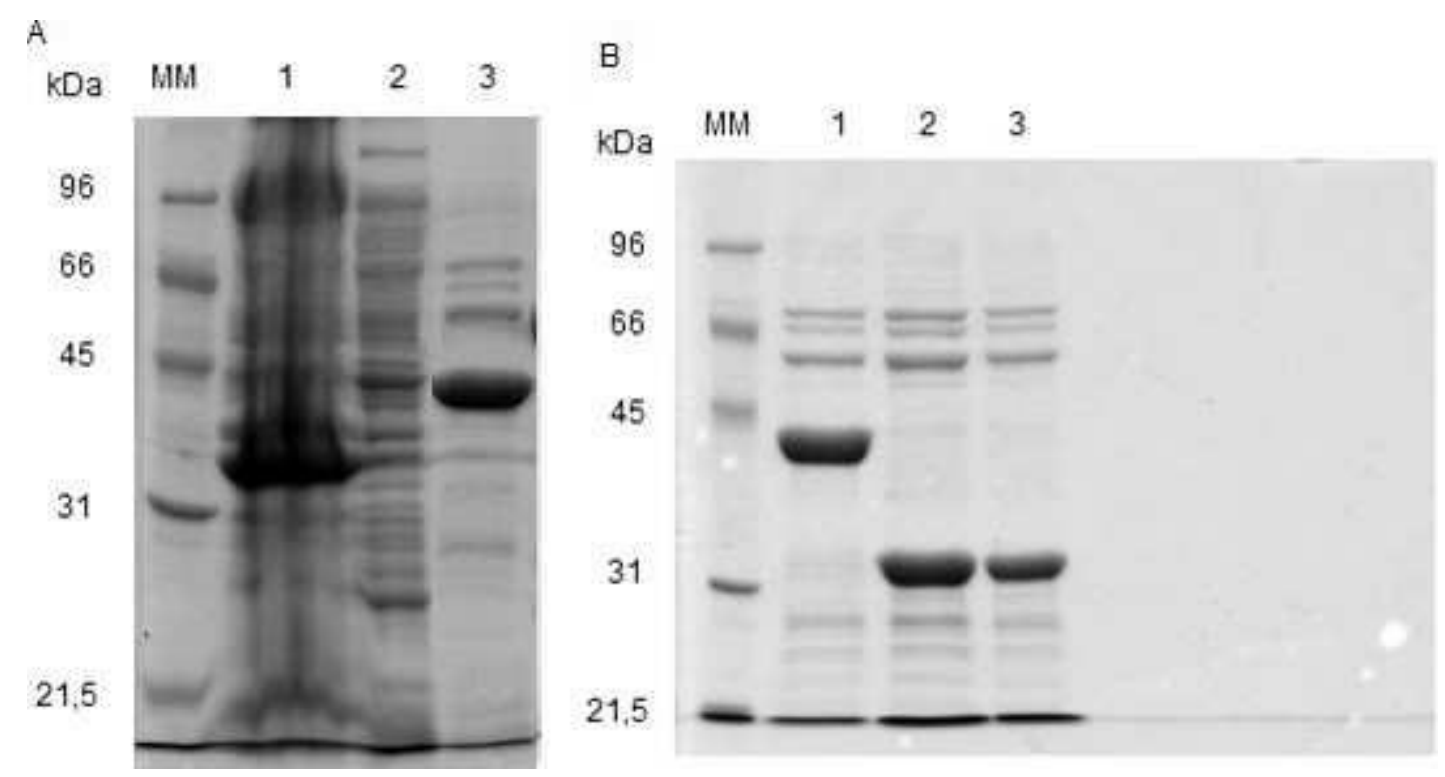

Figura 18 - Gel de poliacrilamida contendo a expressão da TtGH62 utilizando meio autoindutor. Eletroforese em Gel de SDS- Page $12 \%$ em A e B. A: Representa as amostras logo após a expressão, sendo 1 o extrato bruto, 2 o flow-through da primeira purificação e 3 a fração proteica após a primeira purificação, todos tendo como referencia o MM (marcador de massa molecular). B: Representa as amostras após a primeira purificação e após a clivagem com TEV protease, sendo 1 resultado da primeira purificação, 2 e 3 são mesmas amostras da proteína após a clivagem da cauda de histidina e portanto com a proteín de interesse na banda de $31 \mathrm{kDa}$.

Fonte: Elaborada pela autora.

A purificação da enzima, como dito anteriormente, foi feita em duas etapas, uma purificação por cromatografia de afinidade e outra cromatografia de exclusão por tamanho molecular. A primeira etapa exigiu uma triagem das melhores concentrações de imidazol para a eluição total da proteína com menor quantidade de contaminantes. Para tal método foram feitos 9 tampões "A" com as seguintes frações de imidazol: A1 com $150 \mathrm{mM}$ de imidazol, A2 com $160 \mathrm{mM}$ de imidazol, A3 
com $170 \mathrm{mM}$ de imidazol, A4 com $180 \mathrm{mM}$ de imidazol, A5 com $190 \mathrm{mM}$ de imidazol, A6 com 200 mM de imidazol, A7 com 210 mM de imidazol, A8 com 220 $\mathrm{mM}$ de imidazol e A9 com $230 \mathrm{mM}$ de imidazol. O resultado da eluição de todas as frações citadas está contido na Figura 19. As amostras coletadas ainda não apresentavam um alto grau de pureza, portanto, foi necessária uma segunda etapa de purificação.

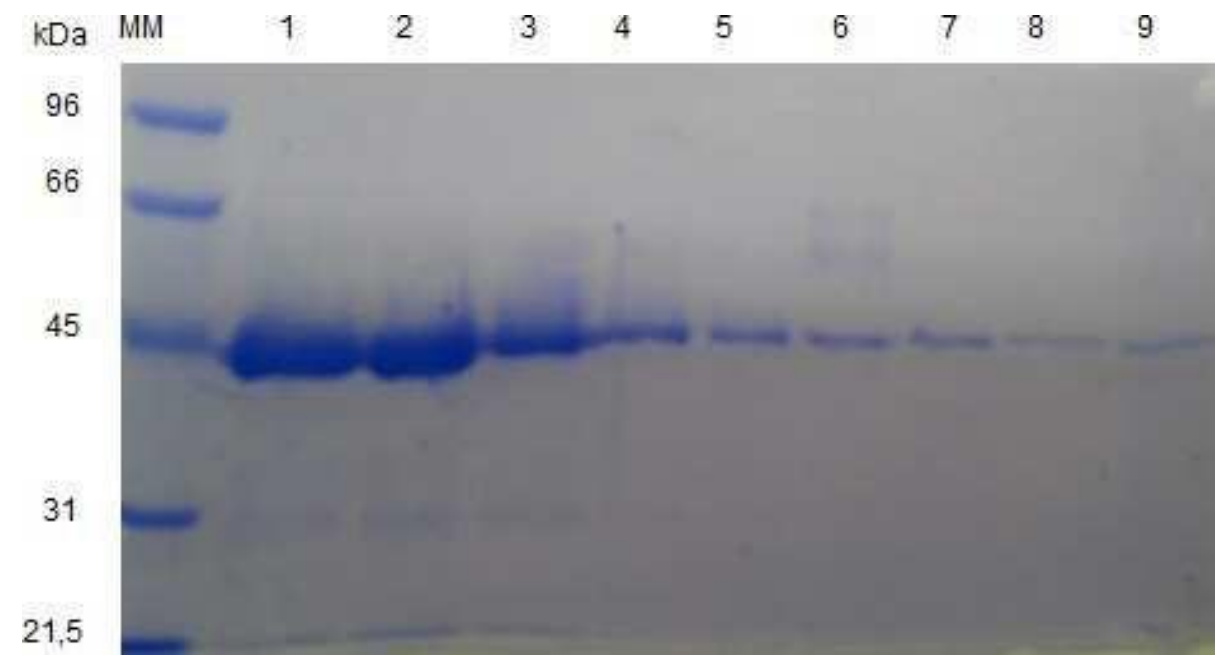

Figura 19 - Gel de poliacrilamida contendo as amostras da primeira purificação por afinidade da TtGH62. Eletroforese em Gel de SDS-Page 12\%. As amostras 1 a 9 são referentes aos tampões: $A 1, A 2, A 3, A 4, A 5, A 6, A 7, A 8$ e A9, respectivamente. MM é referente ao marcador de massa molecular.

Fonte: Elaborada pela autora.

Após a primeira purificação utilizando a resina de níquel, foi feita a clivagem da cauda de histidina com o uso da protease TEV e, em seguida, passou-se novamente na coluna de níquel para eluir a proteína sem a cauda. De acordo com a metodologia, as únicas macromoléculas retidas na coluna de níquel seriam aquelas com a cauda de histidina, as demais passariam pela coluna durante a lavagem ou eluição. A proteína clivada está representada em B na Figura 18. A segunda purificação foi através de filtração em gel com o auxilio de uma coluna Hiload 16/60 Superdex 75 . Coletou-se 20 alíquotas ( $80 \mathrm{~mL}$ a $100 \mathrm{~mL}$ ) referentes ao maior pico de absorção correspondente a fração eluida da proteína, como representado na Figura 21. Para a confirmação da proteína pura foi feita uma eletroforese em gel de policrilamida $12 \%$ com amostras referentes a 9 alíquotas coletadas; o resultado se encontra na Figura 20. $O$ gel apresentado na Figura 
demonstra que obteve-se um grau de pureza suficiente para a proteína ser cristalizada, além de uma concentração de aproximadamente $5 \mathrm{mg} / \mathrm{mL}$.

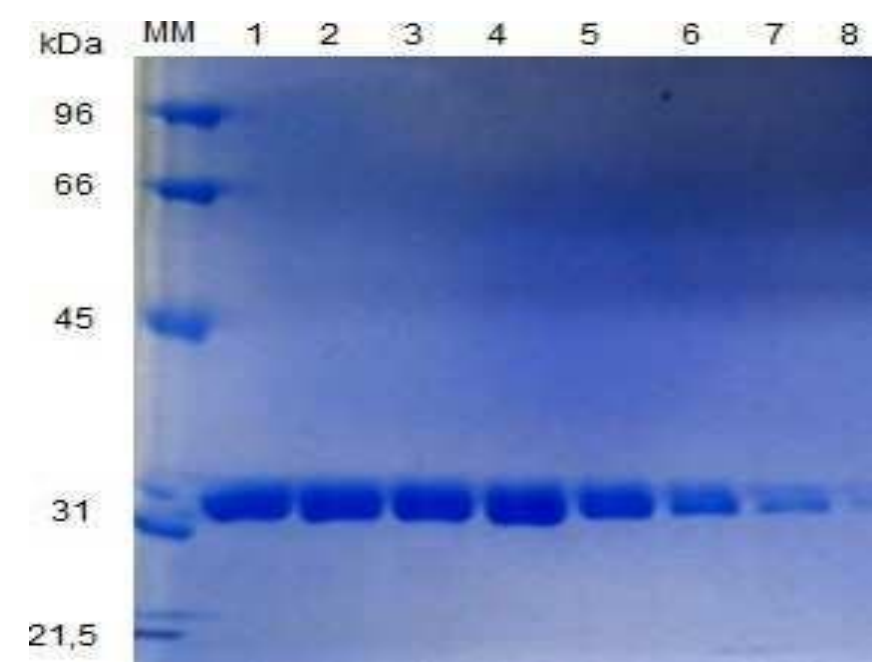

Figura 20 - Gel de poliacrilamida contendo as amostras da segunda purificação por cromatografia de exclusão por massa molecular da TtGH62. 1 a 9 representam as alíquotas coletados durante a purificação e MM é o marcador de massa molecular.

Fonte: Elaborada pela autora.

Os experimentos para obtenção da proteína pura foram realizados com sucesso. As próximas etapas experimentais seriam para análise da enzima estruturalmente e funcionalmente. O passo mais importante para dar continuidade as investigações é a escolha do tampão, pois todas as proteínas são sujeitas a diferentes comportamentos quando submetidas a determinadas substâncias. A fluorimetria diferencial de varredura nos auxiliou para determinar as melhores condições para a arabinofuranosidase de $T$. terrestris, permitindo assim a determinação do melhor tampão para a enzima. Os resultados aparecem em forma de tabela, com uma gradação de cores que variam entre vermelho (indica resultado de menor estabilidade) até verde (indica resultados de maior estabilidade). A adição de $\mathrm{NaCl}$ gerou resultados de maior instabilidade proteica. Esse resultado indica que não há nenhum efeito sinérgico do sal com o tampão que auxiliasse uma estabilização protéica. A variação de $\mathrm{pH}$ demonstrou que a faixa entre 5,5 a 7,5 é mais tolerável para a enzima, sendo $7,5 \mathrm{seu}$ pH ideal. Avaliando cada condição tamponante, alguns causaram instabilidade, sendo esses: acetato de Amônio, Hepes, Ácido Cítrico, Carbonatos e Fosfatos. Os melhores tampões foram Tris e Bis-Tris. Todos os dados estão contidos na Tabela 3. 


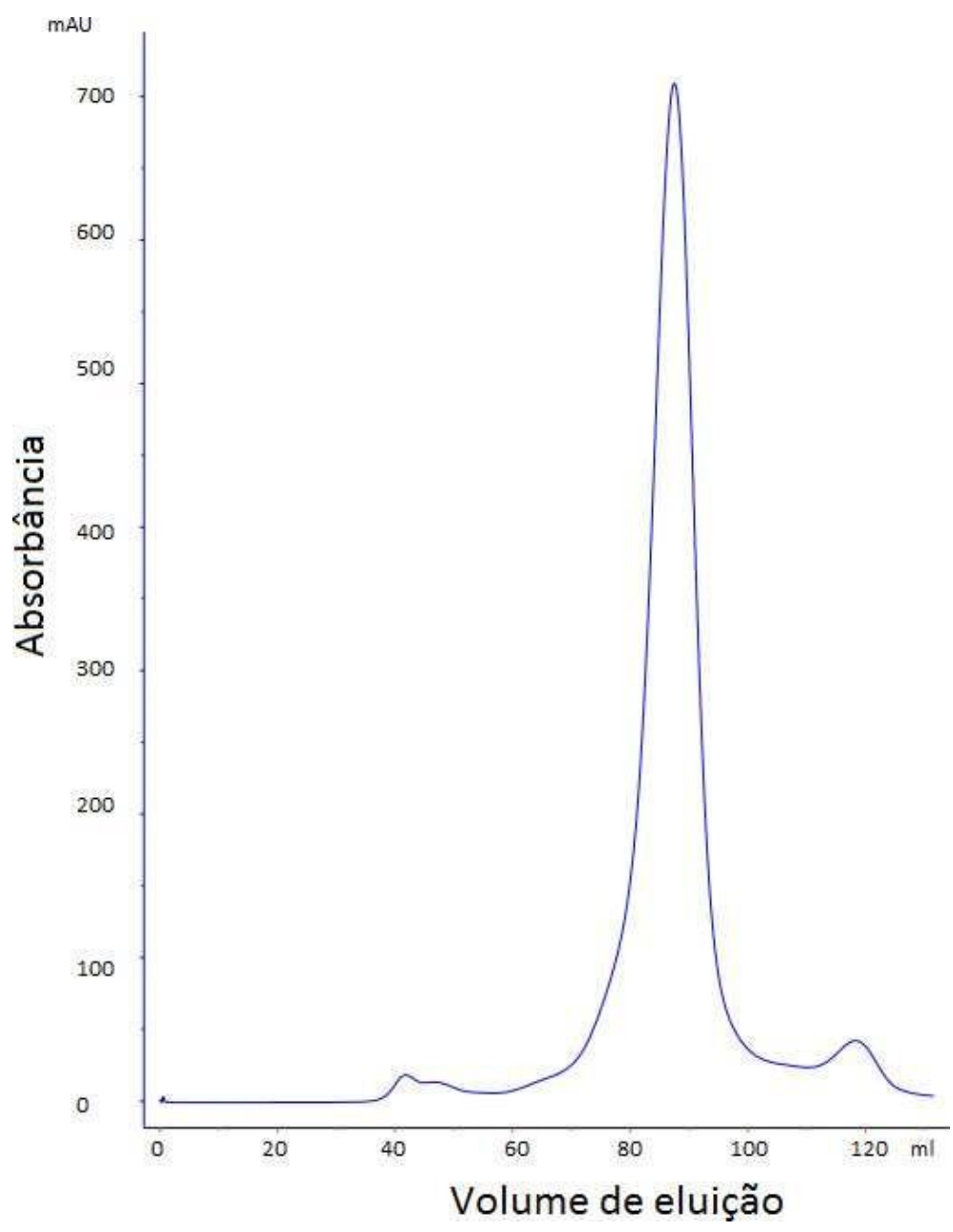

Figura 21-Espectro de eluição da Cromatografia de Exclusão Molecular. O pico que atinge 700 mAU representa a fração eluida da proteína.

Fonte: Elaborado pela autora.

Outro parâmetro importante que foi avaliado é a Tm (temperatura de melting) para cada condição tamponante, demonstrado na Figura 23. Uma visão geral de todas as condições mostrou que a Tm média é em torno de $61^{\circ} \mathrm{C}$, um alto valor, sugerindo uma alta estabilidade protéica. Outra observação importante é a relação entre $\circ \mathrm{pH}$ e a Tm, pois nota-se uma diminuição da Tm quando o pH encontra-se muito alto ou muito baixo. A TtGH62 na condição A4 (ácido cítrico em pH 3) possui uma Tm de $37 \stackrel{\circ}{\circ} \mathrm{C}$, gerando uma perda de estabilidade estrutural possivelmente causada por ionização da cadeia lateral de aminoácidos.

O mesmo ocorre com o tampão carbonato de sódio em pH 10. De acordo com a análise do Gel Nativo da Figura 22, é notável uma banda única a faixa de $140 \mathrm{kDa}$ referente ao estado oligomérico. Portanto é correto 
concluir que a proteína estu ada não é um monômero, mas provavelmente um tetrâmero.

\section{kDa}

\section{$\begin{array}{llllll}M M & 1 & 2 & 3 & 4 & 5\end{array}$}

440
232
140

66

Figura 22 - Imagem do Gel Nativo.1,2,3,4,5) TtGH62 após cromatografia de afinidade em diferentes concentrações, todas na faixa de $140 \mathrm{kDa}$. MM) marcador molecular.

Fonte: Elaborada pela autora. 
Tabela 3 - Estabilidade da enzima TtGH62 pela técnica DSF através da variação do pH e concentração de sal. Os tampões que representam maior estabilidade para a proteína estão destacados em verde escuro e aqueles que são avaliados com menor estabilidade para a proteína são destacados em vermelho escuro.

\begin{tabular}{|c|c|c|c|c|c|c|c|c|c|}
\hline Poço & $\mathrm{pH}$ & $\begin{array}{l}\text { tampão }\left([]^{f}=\right. \\
\text { sU mIVI) }\end{array}$ & $\begin{array}{l}{[\mathrm{NaCl}]} \\
(\mathrm{mM})\end{array}$ & $\begin{array}{l}\text { Temperatura } \\
\text { de Ileltıng }\end{array}$ & Poço & $\mathrm{pH}$ & $\begin{array}{l}\text { tampão ([ ]f } \\
=50 \mathrm{mM})\end{array}$ & $\begin{array}{l}{[\mathrm{NaCl}]} \\
(\mathrm{mM})\end{array}$ & $\begin{array}{l}\text { Temperatura } \\
\text { de Melting }\end{array}$ \\
\hline A1 & - & Água & 0 & 62,00 & C1 & 7,5 & $\begin{array}{l}\text { Fosfato de } \\
\text { Sódio }\end{array}$ & 0 & 55,00 \\
\hline A2 & 7,2 & HCl & 0 & & C2 & 7,5 & Tris & 0 & 63,00 \\
\hline A3 & 2,0 & $\mathrm{HCl}$ & 0 & 36,00 & $\mathrm{C3}$ & 8,0 & Imidazol & 0 & 59,00 \\
\hline A4 & 3,0 & Acido Cítrico & 0 & 45,00 & $\mathrm{C} 4$ & 8,0 & Hepes & 0 & 59,00 \\
\hline A5 & 4,0 & $\begin{array}{ll}\text { Citrato } & \text { de } \\
\text { Sódio } & \end{array}$ & 0 & 56,00 & C5 & 8,0 & Tris & 0 & 62,00 \\
\hline A6 & 4,5 & $\begin{array}{l}\text { Acetato de } \\
\text { Sódio }\end{array}$ & 0 & 56,00 & $\mathrm{C} 6$ & 8,0 & Bicina & 0 & 56,00 \\
\hline A7 & 4,7 & $\begin{array}{ll}\text { Citrato } & \text { de } \\
\text { Sódio } & \end{array}$ & 0 & 60,00 & $\mathrm{C} 7$ & 8,5 & Tris & 0 & 60,00 \\
\hline A8 & 5,0 & $\begin{array}{ll}\text { Acetato } & \text { de } \\
\text { Sódio } & \end{array}$ & 0 & 60,00 & C8 & 9,0 & Bicina & 0 & 50,00 \\
\hline A9 & 5,0 & $\begin{array}{l}\text { Fosfato de } \\
\text { Potássio }\end{array}$ & 0 & 60,00 & C9 & 9,5 & $\begin{array}{l}\text { Carbonato } \\
\text { de Sódio }\end{array}$ & 0 & 44,00 \\
\hline A10 & 5,5 & $\begin{array}{l}\text { Citrato de } \\
\text { Sódio }\end{array}$ & 0 & 60,00 & C10 & 10,0 & $\begin{array}{l}\text { Carbonato } \\
\text { de Sódio }\end{array}$ & 0 & 40,00 \\
\hline A11 & 5,5 & $\begin{array}{l}\text { Fosfato de } \\
\text { Sódio }\end{array}$ & 0 & 61,00 & C11 & 3,0 & $\begin{array}{l}\text { Acido } \\
\text { Cítrico }\end{array}$ & 300 & 37,00 \\
\hline A12 & 5,8 & Mes & 0 & 62,00 & C12 & 4,5 & $\begin{array}{l}\text { Acetato de } \\
\text { Sódio }\end{array}$ & 300 & 53,00 \\
\hline B1 & 6,0 & $\begin{array}{ll}\text { Fosfato } & \text { de } \\
\text { Potássio } & \end{array}$ & 0 & 60,00 & D1 & 5,0 & $\begin{array}{l}\text { Fosfato de } \\
\text { Potássio }\end{array}$ & 300 & 60,00 \\
\hline B2 & 6,0 & Bis-Tris & 0 & 63,00 & D2 & 5,5 & Bis-Tris & 300 & 61,00 \\
\hline B3 & 6,2 & Mes & 0 & 62,00 & D3 & 5,5 & $\begin{array}{l}\text { Citrato de } \\
\text { Sódio }\end{array}$ & 300 & 61,00 \\
\hline B4 & 6,5 & $\begin{array}{l}\text { Fosfato de } \\
\text { Sódio }\end{array}$ & 0 & 60,00 & D4 & 5,8 & Mes & 300 & 61,00 \\
\hline B5 & 6,5 & $\begin{array}{l}\text { Cacodilato de } \\
\text { Sódio }\end{array}$ & 0 & 61,00 & D5 & 6,0 & Bis-Tris & 300 & 62,00 \\
\hline B6 & 6,5 & Bis-Tris & 0 & 62,00 & D6 & 6,5 & $\begin{array}{l}\text { Cacodilato } \\
\text { de Sódio }\end{array}$ & 300 & 61,00 \\
\hline B7 & 6,5 & Mes & 0 & 62,00 & D7 & 6,5 & $\begin{array}{l}\text { Fosfato de } \\
\text { Sódio }\end{array}$ & 300 & 60,00 \\
\hline B8 & 6,7 & Bis-Tris & 0 & 64,00 & D8 & 7,0 & Bis-Tris & 300 & 61,00 \\
\hline B9 & 7,0 & $\begin{array}{ll}\text { Fosfato } & \text { de } \\
\text { Potássio } & \\
\end{array}$ & 0 & 57,00 & D9 & 7,0 & Hepes & 300 & 61,00 \\
\hline B10 & 7,0 & Hepes & 0 & 62,00 & D10 & 7,3 & $\begin{array}{l}\text { Acetato de } \\
\text { Amônio }\end{array}$ & 300 & 60,00 \\
\hline B11 & 7,0 & Bis-Tris & 0 & 63,00 & D11 & 7,5 & Tris & 300 & 62,00 \\
\hline B12 & 7,3 & $\begin{array}{l}\text { Acetato de } \\
\text { Amônio }\end{array}$ & 0 & 60,00 & D12 & 8,0 & Hepes & 300 & 57,00 \\
\hline
\end{tabular}

Fonte: Elaborada pela autora. 


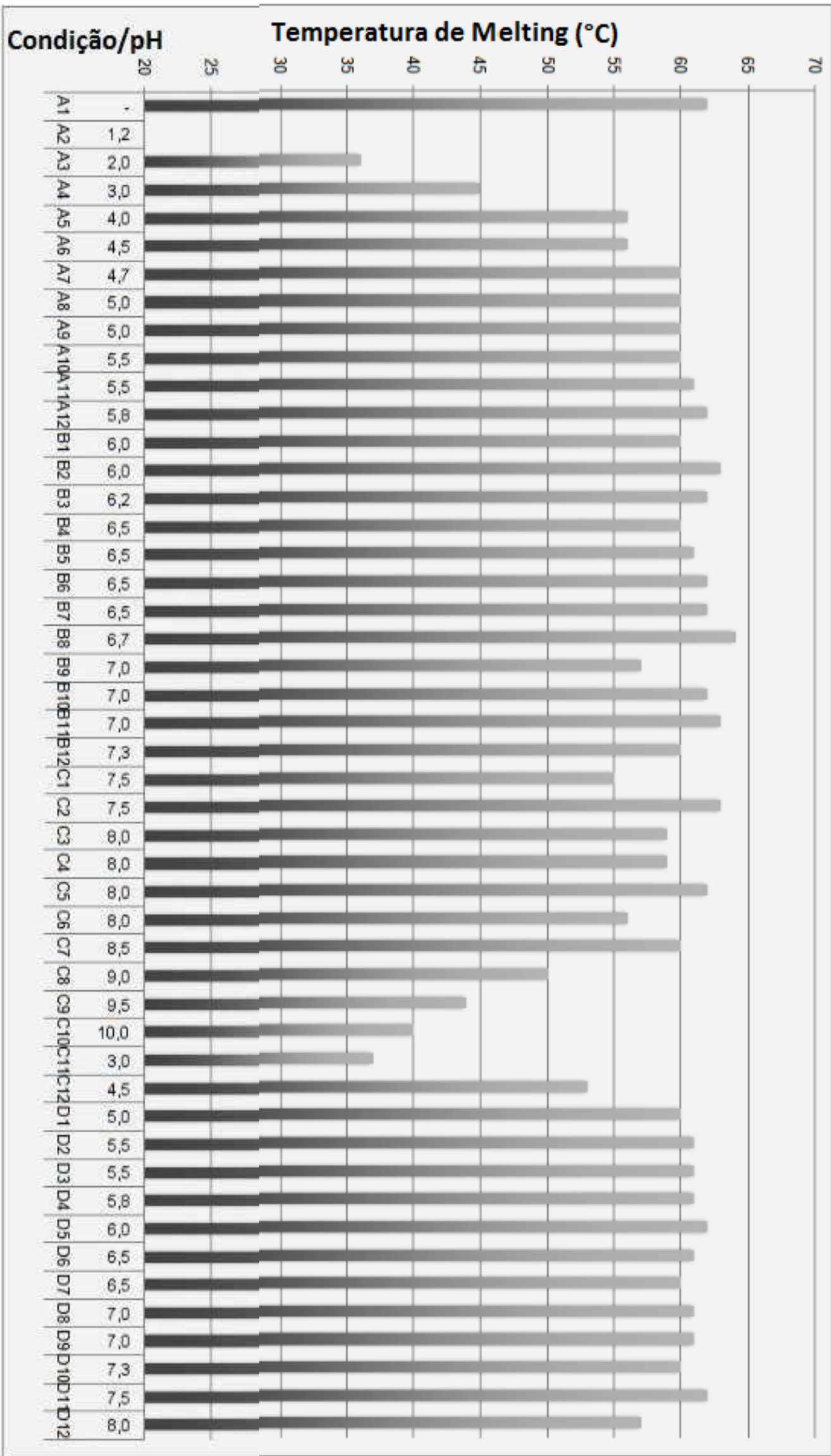

Figura 23 - Gráfico de estabilidade térmica. Valores da Temperatura de melting de acordo com os tampões utilizados na técnica de DSF.

Fonte: Elaborada pela aut ra. 


\subsection{ENSAIOS DE CRISTALIZAÇÃO E RESOLUÇÃO DA ESTRUTURA}

\section{TRIDIMENSIONAL}

O estudo estrutural de uma proteína é fundamental para o completo entendimento da sua função, a cristalização é uma técnica importante para a determinação da estrutura da enzima e, consequentemente, da sua caracterização como um todo. Para a obtenção dos cristais, uma série de eventos são necessários para o processo de supersaturação, a partir de uma proteína pura para chegar à formação de agregados ordenados, e finalmente o crescimento do cristal. Após o processo de cristalização, foram obtidos cristais de simetria ortorrômbica (1222; a = $75,267 \AA, b=79,747 \AA, c=82,922 \AA$ ) e difrataram até $1,8 \AA$ de resolução, compreendendo 301 resíduos de aminoácidos da proteína. As coordenadas e os fatores de estrutura foram depositados no PDB sob o código: 6CC7 (TtGH62). O alinhamento da estrutura foi feito utilizando o programa BLAST e está em anexos.

Os valores de $R_{\text {factor }}$ e $R_{\text {free }}$ cristalográficos finais foram de $15,0 \%$ e $19,5 \%$ respectivamente. O diagrama de Ramachandran identifica as configurações permitidas de uma proteína, pois é uma representação visual das combinações dos angulos diedros $\Psi$ e $\Phi$ em um esqueleto peptídico, podendo ser permitidos ou não permitidos devido a impedimentos estéricos.(52) De acordo com a tabela, o modelo proposto é de boa qualidade, com mais de $96 \%$ dos resíduos de aminoácidos modelados apresentando ângulos espacialmente possíveis, em regiões permitidas no gráfico de Ramachandran. Uma molécula estava presente na unidade assimétrica. As estatísticas de refinamento estão na Tabela 4. Como exemplificados na Figura 24, foram observados diversos cristais no kit Classic (Hampton). A condição de crescimento dos cristais foi acetato de sódio $0,1 \mathrm{M} \mathrm{e}$ sulfato de amônio $2 \mathrm{M} \mathrm{com} \mathrm{pH} \mathrm{4,6} \mathrm{a} 18{ }^{\circ} \mathrm{C}$. O tempo necessário para observar formação de cristais de TtGH62foi de aproximadamente 30 dias. Foi necessária uma demasiada concentração de proteína para o ensaio de cristalização, chegando a aproximadamente $20 \mathrm{mg} / \mathrm{mL}$. Os cristais difrataram até $1,8 \AA$ usando o feixe de luz da linha MX2 do LNLS- Campinas, a imagem dos cristais está na Figura 24. O padrão de difração e as estatísticas de refinamento estão na Figura 25 e Tabela 3. 


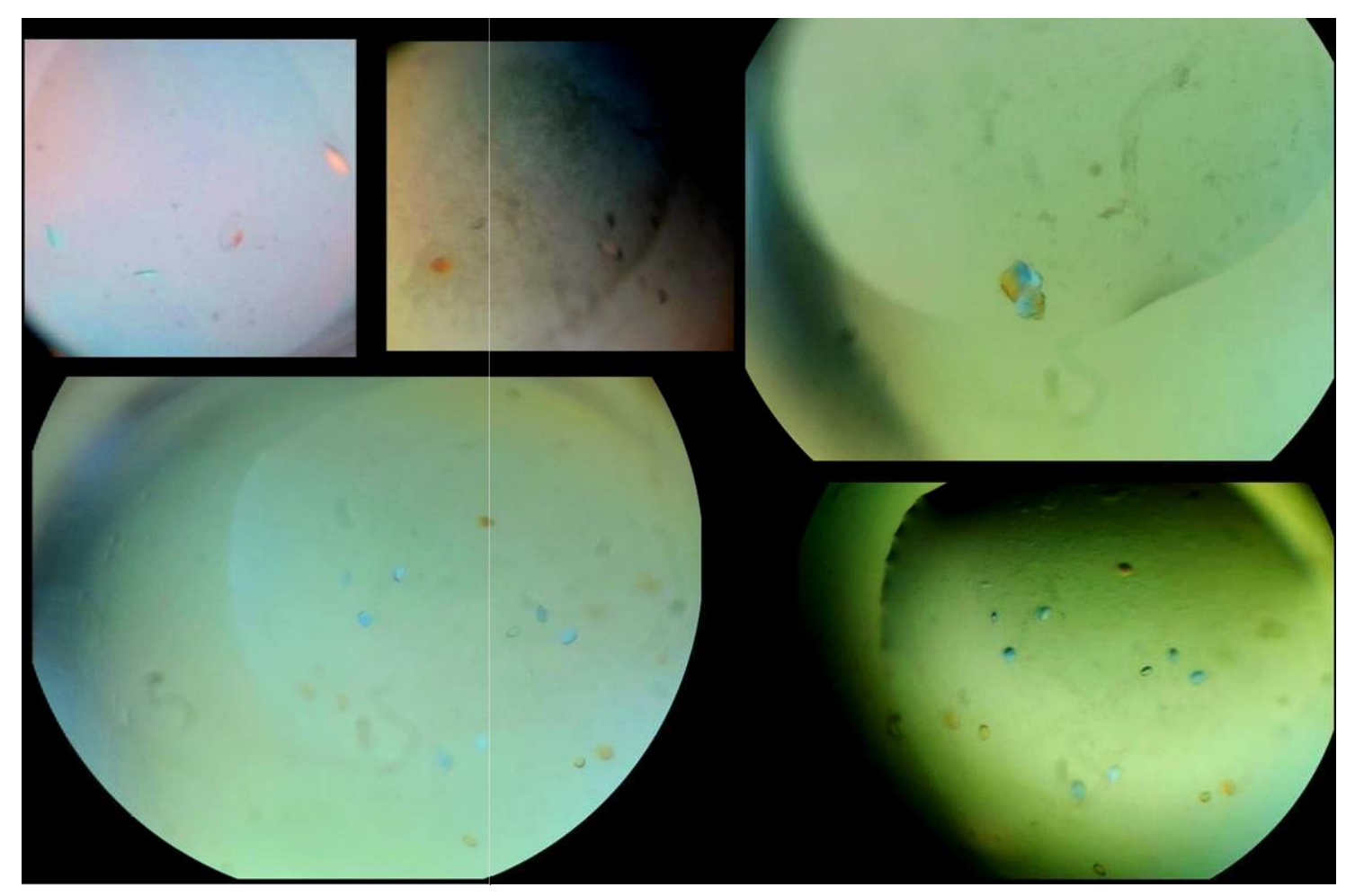

Figura 24 - Foto dos cristais obtidos no kit Classic a partir de $20 \mathrm{mg} / \mathrm{mL}$ de proteína 30 dias conservados a $18{ }^{\circ} \mathrm{C}$.

Fonte: Elaborada pela autora.

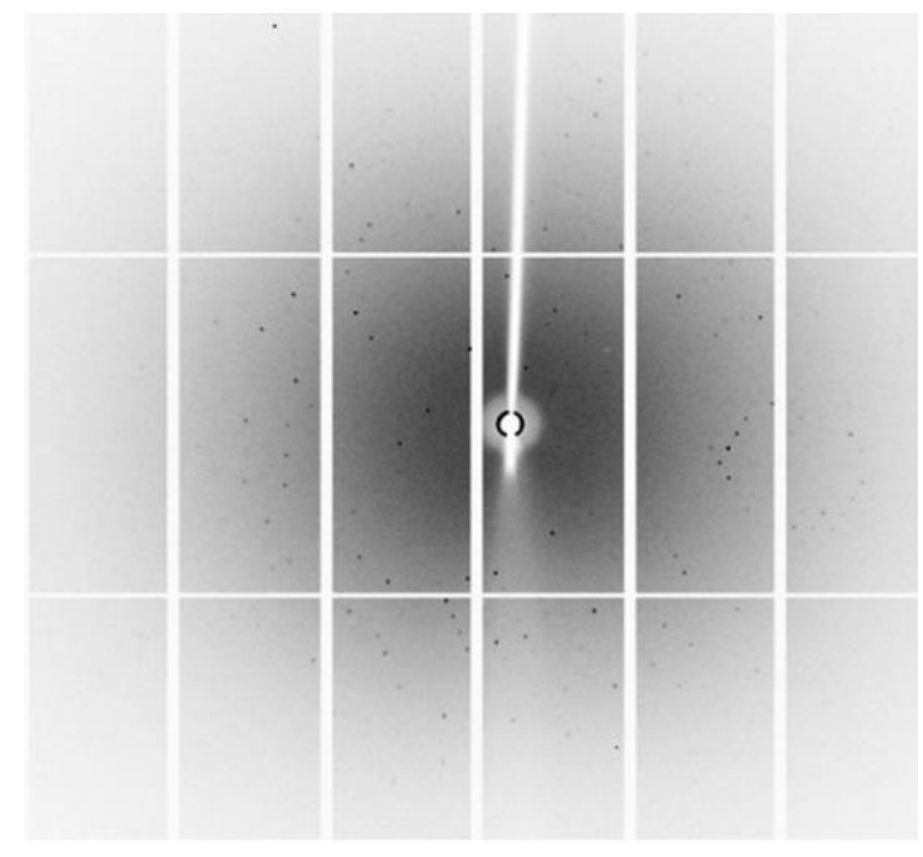

Figura 25- Imagem do padrão de difração obtido a partir do cristal de TtGH62

Fonte: Elaborado pela autora. 
Tabela 4 - Estatísticas cristalográficas referentes a coleta, processamento e refinamento do cristal da TtGH62. Valores entre parênteses referem-se à camada mais alta de resolução.

\begin{tabular}{|c|c|}
\hline Parâmetro & $\begin{array}{l}\text { Arabinofuranosidase } \quad \text { de } T \text {. } \\
\text { terrestris }\end{array}$ \\
\hline Comprimento de onda (Á) & 1,4586 \\
\hline Resolução (Á) & $33,05-1,87(1,91-1,87)$ \\
\hline Grupo espacial & $/ 222$ \\
\hline $\mathbf{a}, \mathbf{b}, \mathbf{c}(\stackrel{\AA}{\mathrm{A}})$ & $75,27,79,75,82,92$ \\
\hline Reflexões totais & 115560 (3649) \\
\hline Reflexões únicas & 20946 (1318) \\
\hline Multiplicidade & $5,5(2,8)$ \\
\hline Completeza (\%) & $99,8(97,4)$ \\
\hline$\langle\mathrm{I} / \sigma(\mathrm{I})\rangle$ & $11,9(2,2)$ \\
\hline B-fator de Wilson $\left(\AA^{2}\right)$ & 21,6 \\
\hline Rmerge (\%) & $7,1(38,6)$ \\
\hline Rmeas(\%) & $8,4(52,2)$ \\
\hline CC1/2 (\%) & $99,8(83,8)$ \\
\hline $\mathbf{R}_{\text {factor }} / \mathbf{R}_{\text {free }}$ & $14,6 / 19,3$ \\
\hline Número de átomos não hidrogênio & 2647 \\
\hline Macromoléculas & 2334 \\
\hline Agua & 297 \\
\hline \multicolumn{2}{|l|}{ Ramachandran (\%) } \\
\hline Região favorável & 96,4 \\
\hline Região não permitida & 0,33 \\
\hline Clashscore & 0,44 \\
\hline$B_{\text {fator }}$ médio $\left(\dot{A}^{2}\right)$ & 23,69 \\
\hline Solvente (\%) & 31,30 \\
\hline Aminoácidos & 304 \\
\hline RMSDligação (Å) & 0,014 \\
\hline RMSDângulo ( ${ }^{\circ}$ ) & 1,628 \\
\hline
\end{tabular}

Fonte: Elaborada pela autora 


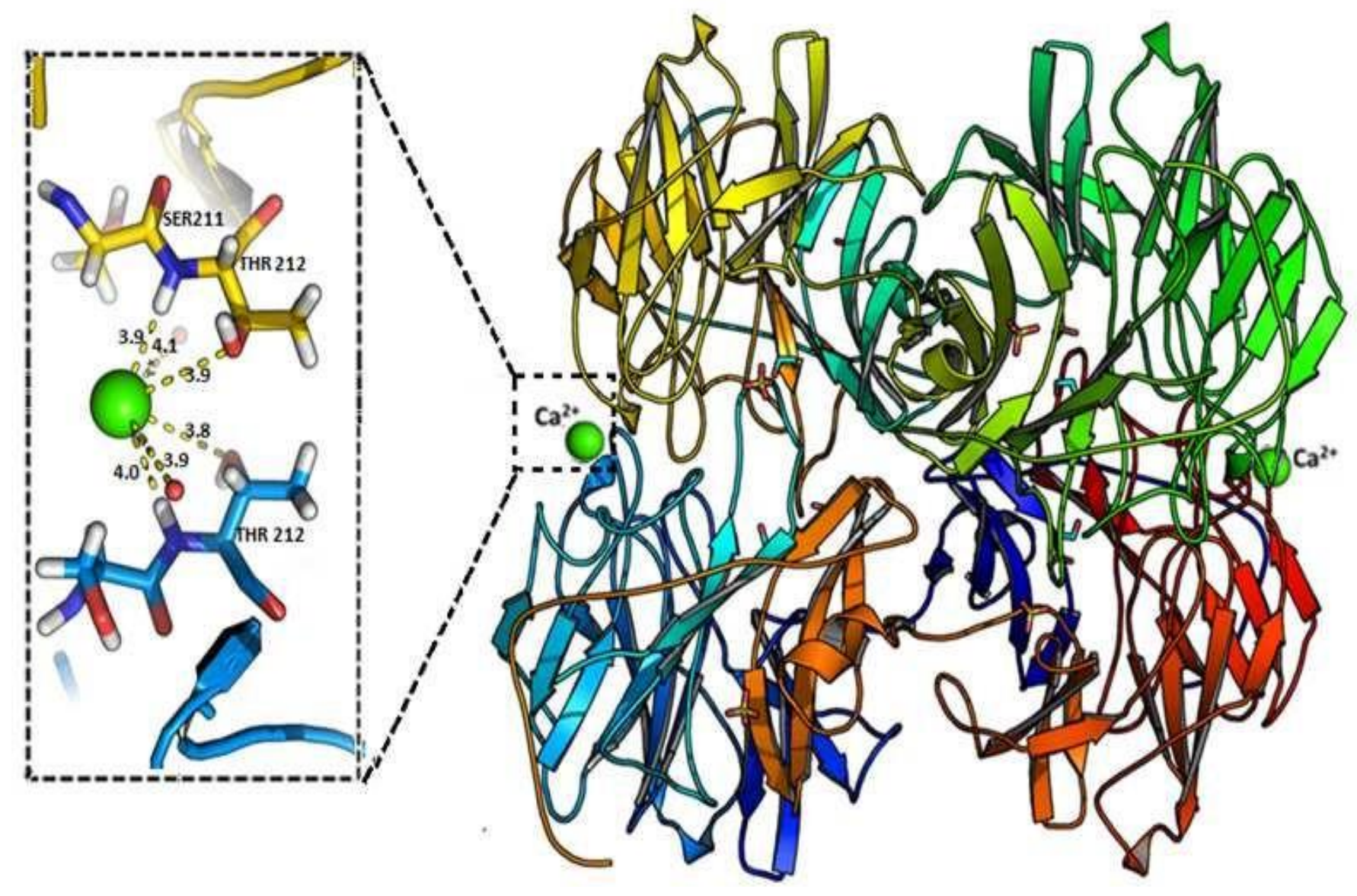

Figura 26 - Imagem da estrutura tridimensional da enzima TtGH62 após o refinamento. Em verde são representados os íons Cálcio.

Fonte: Elaborada pela autora.

A Figura 26 mostra o modelo refinado da estrutura, o qual em geral apresentou um enovelamento denominado beta-propeller. $O$ enovelamento de beta-propeller tem como principais características suas dobras toroidais; nas quais são repetidas 4 fitas betas dispostas de forma antiparalela, contendo cinco "pás"; sendo tetramérica em seu estado nativo. Em todo o arranjo molecular existe apenas uma ponte dissulfeto intercadeia em cada monômero. 

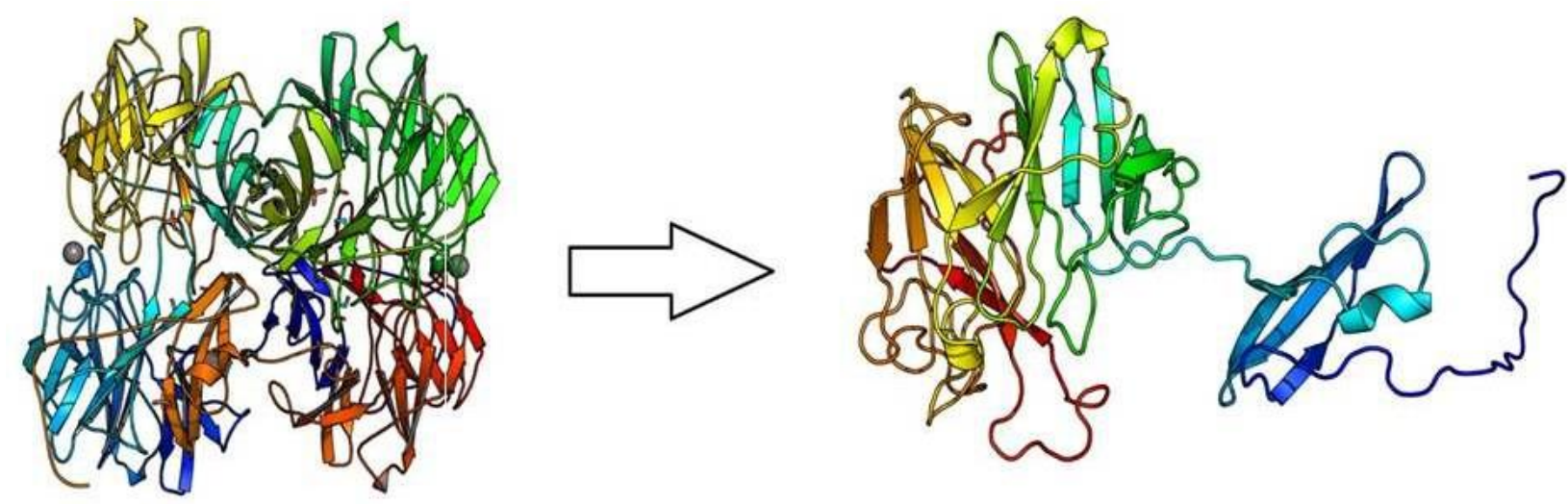

Figura 27- Esquema represe tativo da subunidade de TtGH62 e sua forma te ramérica.

Fonte: Elaborado pela autora.

A ponte dissulfeto ocorre entre os resíduos de Cys300 (localizada na alfa hélice 4 da região $C$ terminal) e Cys32 (localizada no primeiro loop da região $\mathrm{N}$ terminal). Possui um sítio de ligação ao íon Cálcio, curiosamente compartilhado pelo dímero, um sítio altamente conservado na família Comparando todas as proteínas similares, a TtGH62 teve sua estrutura conservada em relação ao enovelamento de beta propeller. No entanto, algo diferenciado aparecia em sua conformação: $A$ existência de um domain swapping em uma de suas "pás", como demonstra a Figura 27. O domain swapping ocorre quando duas ou mais moléculas fazem uma troca de suas estruturas, com a intenção de formar oligômeros, a partir de suas subunidades monoméricas. Não representando apenas um evento isolado de inovação estrutural, o domain swapping permite a criação de novas interfaces de interação que antes eram inexistentes no monômero (B em anexos). Considerado um mecanismo importante para a inovação da estrutura e função de uma proteína, mesmo sendo muitas vezes.(78) 
constatado, tal mecanismo ainda é pouco compreendido estruturalmente e é considerado um mecanismo em resposta de um processo evolucionário já que o domain swapping resulta em uma molécula ativa e de importância biológica. $(78,81)$ Muitas proteínas são enoveladas de uma maneira que requer uma porção nativa de outra similar, seja para atender uma necessidade termodinâmica ou até para uma condição mais agregada. Em todo caso, a existência de tal interação inespećfica entre parceiros ainda não foi desvendada. $(78,93) \mathrm{Na}$ presente estrutura, o domain swapping representa a porção do beta propeller que geralmente se agrega ao resto da estrutura, no entanto, essa nova interação permitiu que tal porção completasse outra subunidade proteica mutuamente, formando o dímero que é demonstrado Figura 27. O monômero possui um loop de articulação, entre a pá projetada para fora da estrutura e os demais domínios do beta-propeller, chamado de "hinge loop". A existência dessa dobradiça torna possível a formação de uma nova interface entre os monômeros logo após a dimerização via domain swapping. O novo rearranjo molecular torna possível a interação entre dímeros através da nova interface e permitiu a formação de uma estrutura tetramérica. Além disso, a dimerização tornou possível a existência de sítios compartilhados entre porções de duas subunidades associadas.( B em anexos)

A ponte dissulfeto é um dos exemplos no qual os resíduos de cisteínas, um em cada monômero, fazem a ligação covalente, comprovando a associação entre o dímero ligando região $\mathrm{C}$ terminal com $\mathrm{N}$ terminal, como monstra a Figura 30. $\mathrm{O}$ íon cálcio faz interação entre 4 resíduos, sendo 2 de cada subunidade. Portanto, diante do dímero, há 2 íons de cálcio contidos exatamente entre os aminoácidos Thr212 e Ser211, com uma distância de $\sim 4 \AA$ entre cada resíduo e o íon. Como já constatado em outro trabalho, o íon cálcio não possui participação ativa na atividade enzimática. $(62,83)$ Em outras estruturas de GH62 é nitidamente notável que a posição do íon cálcio é conservada, geralmente, entre os resíduos de histidina e cisteína localizando-se na região central do beta propeller. No entanto, como já revisado em outros trabalhos (62), a família GH62 possui dois subgrupos, sendo a proteína do presente trabalho pertencente ao grupo GH62_2, diferente das comentadas anteriormente. Logo, a localização do íon cálcio na estrutura não se encontra na região central e sim em sua região superficial de interação entre dímeros. (62) 
Tabela 5 - Tabela comparativa de proteínas da família GH62 em relação a localização do sítio de ligação ao Cálcio.

\begin{tabular}{|l|l|l|l|l|l|}
\hline Organismo & $\begin{array}{l}\text { Thielavia } \\
\text { terrestris }\end{array}$ & $\begin{array}{l}\text { Coprinopsis } \\
\text { cinerea }\end{array}$ & $\begin{array}{l}\text { Coprinopsis } \\
\text { cinerea }\end{array}$ & $\begin{array}{l}\text { Coprinopsis } \\
\text { cinerea }\end{array}$ & $\begin{array}{l}\text { Podospora } \\
\text { anserina }\end{array}$ \\
\hline $\begin{array}{l}\text { Identificação } \\
\text { no PDB }\end{array}$ & $6 \mathrm{CC} 7$ & $5 \mathrm{~B} 6 \mathrm{~S}$ & - & -- & 4N4B \\
\hline Abreviação & TtGH64 & CcAbf62A & CC1G_01578 & CC1G_15259 & $\begin{array}{l}\text { Pod_ans } \\
\text { Abf62A }\end{array}$ \\
\hline Subfamilia & GH62_2 & GH62_1 & GH62_1 & GH62_1 & GH62_1 \\
\hline Sítio Ca ${ }^{2+}$ & T212/S211 & H346/N279 & H305/C236 & H348/C280 & H285/C219 \\
\hline
\end{tabular}

Fonte: Elaborada pela autora

O íon cálcio pode estar envolvido na termoestabilidade das proteínas, como mencionado no trabalho de Kumagay e colaboradores (98). As mananases são um exemplo de proteínas que possuem a termoestabilidade relacionada ao íon cálcio, e o sítio de ligação ao cálcio é altamente conservado nas mananases bacterianas da família 5 das hidrolases de glicosídeos. De acordo com os estudos de Kumagay e colaboradores, a ligação do cálcio em mananase de Streptomyces thermolilacinus (StMan) e Thermobifida fusca (TMan) ajudam na estabilidade térmica do domínio catalítico das enzimas. No estudo é feito mutantes sem o sítio de ligação ao cálcio, resultando em uma mudança conformacional em um loop envolvido na atividade enzimática, causando uma diminuição da atividade de hidrólise. (100) A participação do íon cálcio na atividade enzimática é reportada nos estudos de Kumagay e colaboradores, o qual através de análises da atividade de hidrólise em diferentes concentrações de cálcio, mostrou que o íon é de fato necessário para melhorar a atividade de hidrólise das mananases. (99)

Uma análise detalhada do sítio catalítico das demais enzimas GH62 caracterizadas permite observar que os resíduos que interagem com o substrato arabinose se conservam independente da sua subclassificação da familia. Como demonstrado nas figuras Figura 29 e Figura 30, o substrato arabinose poderia ser substituído pelo etilenoglicol, formando um sítio catalítico em formato "V" na região central de cada subunidade protéica, tornando um local de fácil acessibilidade e grande exposição ao solvente. (62) 


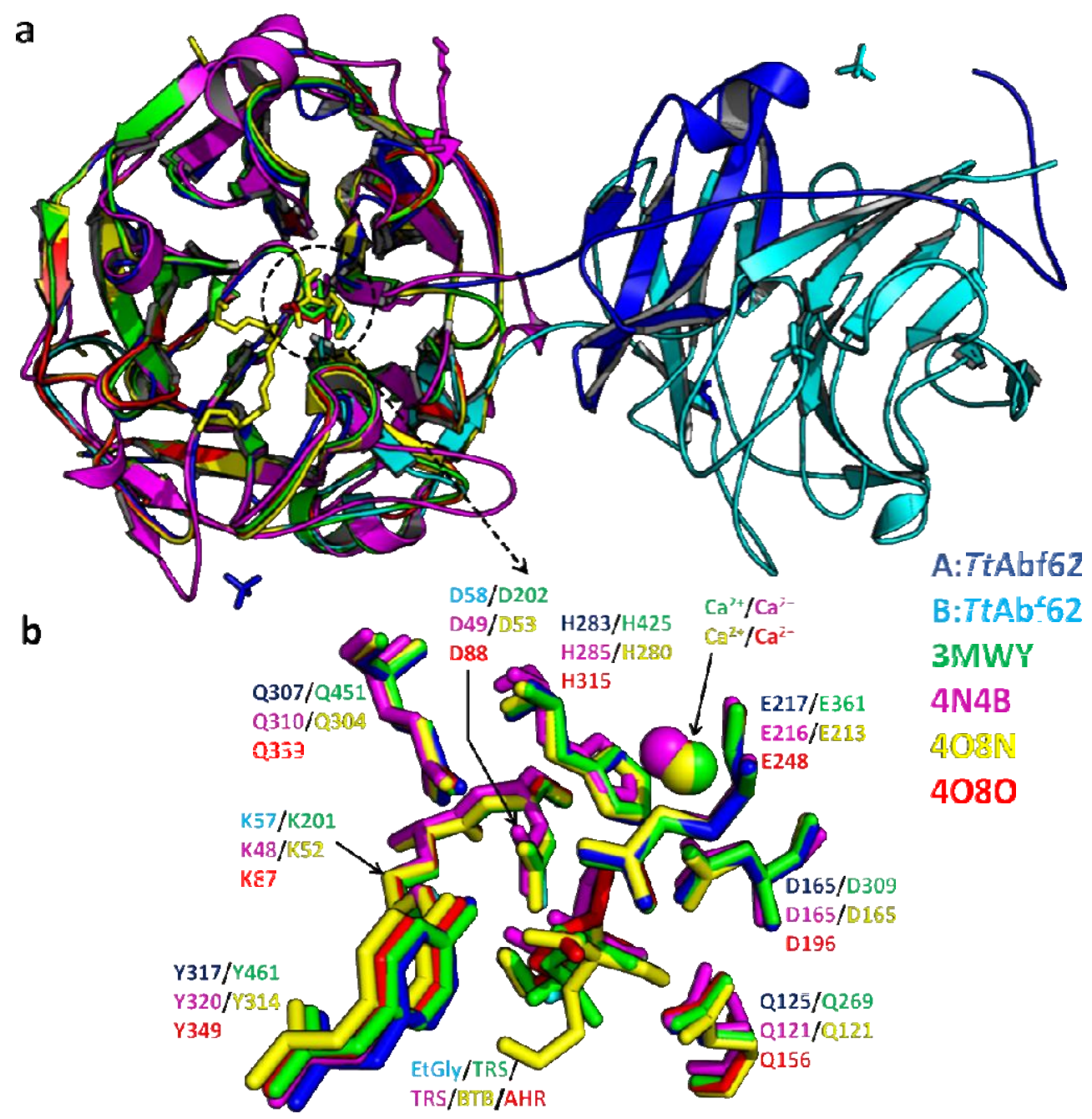

Figura 28 - Comparação da proteína TtGH62 e proteínas homólogas depositadas no PDB. a) Estruturas similares de TtGH62 alinhadas, destacando a formação de domain swapping para TtGH62 onde os resíduos D58 e K57 no sítio de atividade e também a molécula de etileno glicol (Et ly) de B com relação à simetria: TtGH62. b) Resíduos no local ativo de TtGH62 semelhante com seu respectivo código (colorido por traços) e ligantes: TtGH62 EtGly ciano; ScAbf62-3MWY TRIS tampão (TRS) verde; PaAbf62A TRIS tampão (TRS) magenta; SthAraf62A-4O8N BIS-TRIS tampão (BTB) amarelo e SthAraf62A-4O8O Alfa-L-Arabinofuranose (AHR) vermelho. Os íons de cálcio (Ca 2+) são representados como esferas com raios arbitrários coloridos por c deias.

Fonte: Elaborada pela autora. 
O aminoácido catalítico Asp58 interagiria com a água e o substrato por uma distância de $2.7 \AA$, assim como Asp165. Outro resíduo que se associa é o Glu217, sendo esse apontado pela literatura como uma cadeia lateral catalítica essencial que se conserva em todas as GH62 junto ao Asp58. De acordo com o trabalho de Wang et al, isso foi confirmado através de mutações sítio dirigidas para esses resíduos especificamente, resultando em uma perda de atividade enzimática. $(83,62)$

A partir de uma análise de superposição de estruturas, pode-se deduzir maiores informações sobre a interação enzima e substrato. As hidroxilas do sacarídeo arabinose interagem com os aminoácidos Asp58 e Asp165 que atuam como base geral. Já o oxigênio da ligação glicosídica possui interação direta com Glu217, que atua como ácido geral. As interações mantidas por Asp58 e Asp165 formam um sítio que seria capaz de acoplar um anel p-nitrofenolato, podendo ou não manter qualquer interação com aminoácidos Asp165 ou Gln125 próximo ao sítio, portanto, torna possível acoplar o subtrato pNP- $\alpha$-L- arabinofuranosídeo.

Muitas vezes o tamanho do resíduo catalítico pode resultar em uma abertura da cavidade, caso ele seja um aminoácido pequeno, tornando a mesma mais larga e capaz de acoplar substratos maiores. Apesar de muitas arabinofuranosidases (especialmente da família GH62) apresentarem um íon cálcio em seu sítio ativo, na arabinofuranosidase de $T$. terrestris não há presença de tal ligante, como comparado na Figura 28 e Tabela 5. O fato de não abrigar o íon cálcio em seu sítio ativo não é inédito e já foi relatado mesma condição na estrutura de outra arabinofuranosidase do fungo Scytalidium thermophilum. (83) O resultado obtido com a GH62 de T.terrestris foi bastante inesperado, levando em consideração a natureza estrutural predominante das proteínas homólogas. Portanto se investiga a possibilidade de uma evolução da oligomerização proteica nessa familia de enzimas. Considerando que se trata de uma enzima oriunda de um organismo termofilico, espera-se que sua termoestabilidade esteja relacionada com 0 enovelamento da proteína. A existência de algumas características estruturais confere a macromolécula regiões de alta hidrofobicidade, como, por exemplo, loops mais curtos e resíduos que interagem a favor dessa condição hidrofóbica. (84) 


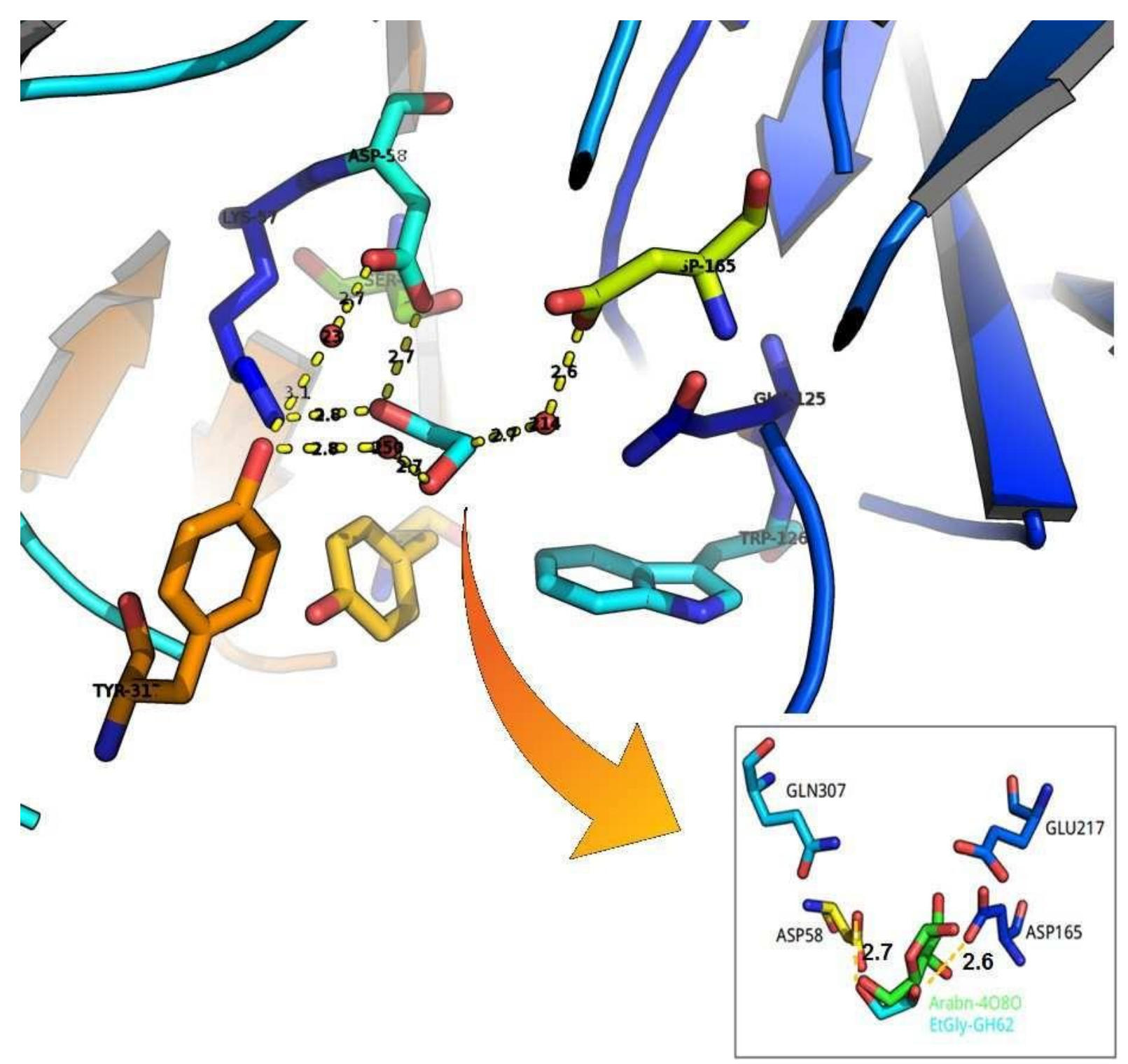

Figura 29-Imagem com sítio ativo de TtGH62 com substrato Arabinano sobreposto ao etilenoglicol e os aminoácidos que interagem ao redor do sítio.

Fonte: Elaborada pela autora . 


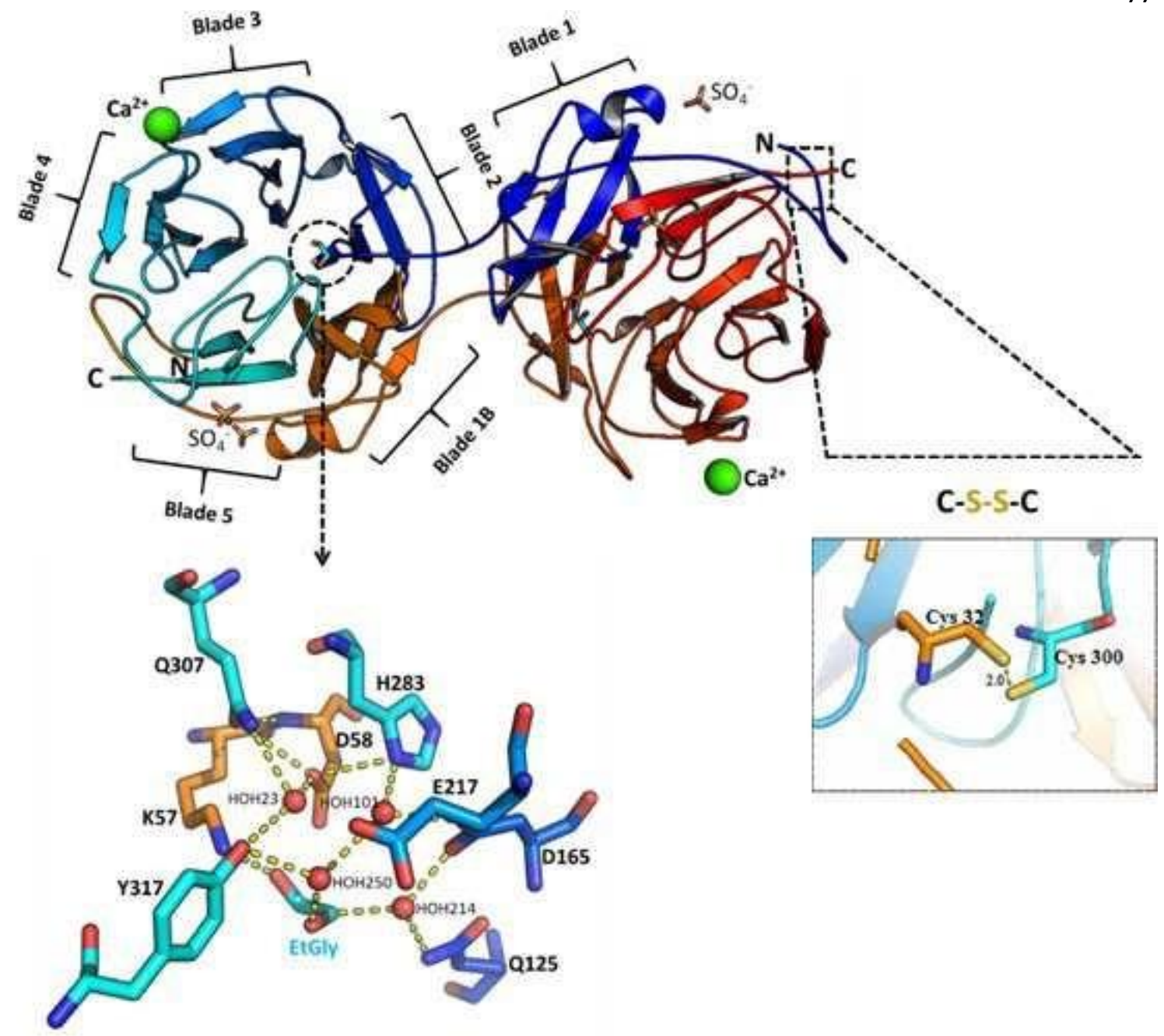

Figura 30-Vista detalhada do TtGH62 domain swapping, o seu sítio ativo e a ponte de dissulfeto. a) Dímero domain swapping de TtGH62 que mostra os terminais $\mathrm{N}$ e $\mathrm{C}$ das suas cadeias de monômeros, respectivamente, que estão ligados através da ligação dissulfeto destacada, onde podem ser cinco pás fazendo o sistema dimérico necessário para estabilizar a estrutura. Os íons de cálcio (Ca 2+) são representados como esferas coloridas verdes, sulfatos (SO4-) e ligantes de etileno glicol (EtGLy) também podem ser observados. b) Uma visão detalhada do sitio ativo com ligações de hidrogênio entre moléculas de água que mediam interações para EtGly e também uma ponte salina entre resíduos Hys283 e Asp58. c) Vista detalhada da ligação dissulfeto entre A: Cys32 (pertencente à região C-terminal) e B: Cys300 (pertencente à região $\mathrm{N}$-terminal).

Fonte: Elaborada pela autora. 


\subsection{CARACTERIZAÇÃO ENZIMÁTICA}

Com a enzima em alto grau de pureza, maior que $95 \%$, foram feitos os ensaios de caracterização enzimática. Um dos ensaios foi feito para avaliar a atividade enzimática em função de diferentes $\mathrm{pHs}$, para definir qual $\mathrm{pH}$ é considerado o "pH ótimo" da proteína, utilizando como substrato o pNP-aAraF. De acordo com os dados exibidos na Figura 31, a enzima possui atividade máxima (100\%) em pH 4,5. A enzima apresenta uma redução na atividade a partir de pHs acima de 5, chegando a ficar inativa em pH 8. No geral, a TtGH62 se encontra de forma ativa entre a faixa de $\mathrm{pH} 4$ a 5,5. Portanto, a enzima apresenta maior atividade em pNP-aAraF no pH de 4,5, apresentando uma diminuição de quase $40 \%$ do seu poder catalítico em pHs abaixo deste e acima de 5,0. Logo, sugere-se que a atividade é fortemente sensível ao $\mathrm{pH}$, sendo importante para maior liberação do arabinofurano ligado na posição do nitrofenil.

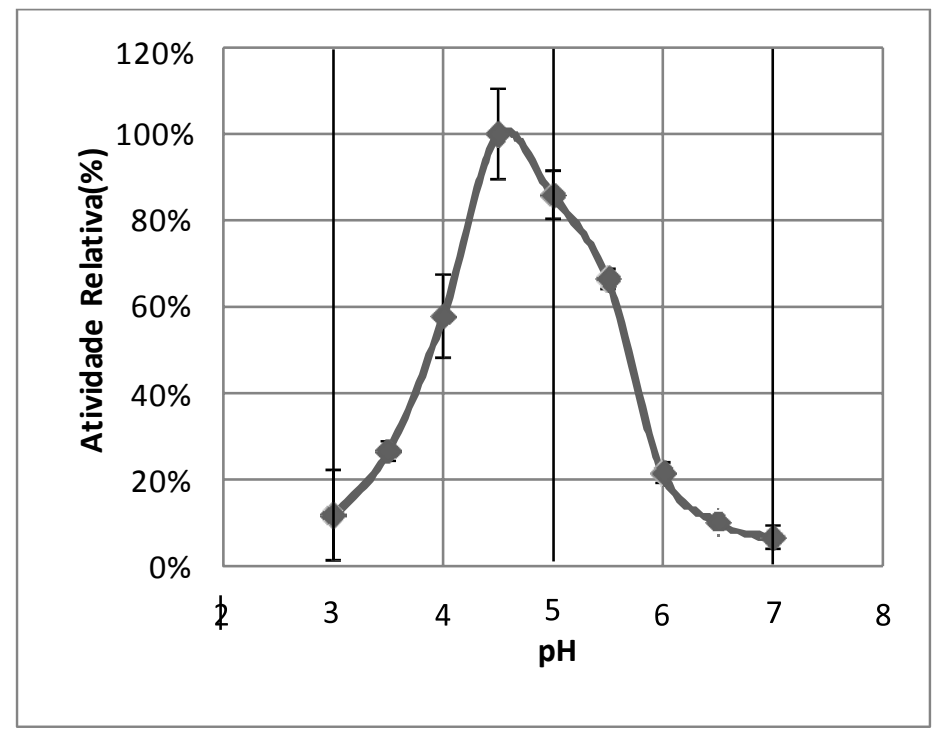

Figura 31 - Gráfico mostrando a atividade relativa em da TtGH62 em função dos pHs, sendo que o melhor $\mathrm{pH}$ é 4,5.

Fonte: Elaborada pela autora. 
O segundo ensaio foi para analisar a atividade da enzima em relação à temperatura. Tal experimento busca definir a temperatura ideal para a atividade da enzima e quais temperaturas causam a sua inativação. De acordo com o gráfico obtido na Figura 32, a TtGH62 fica ativa a partir de $25^{\circ} \mathrm{C}$, utilizando como base 0 substrato pNP-aAraF. No entanto, a partir de $40{ }^{\circ} \mathrm{C}$ a enzima começa a diminuir bruscamente sua atividade relativa.

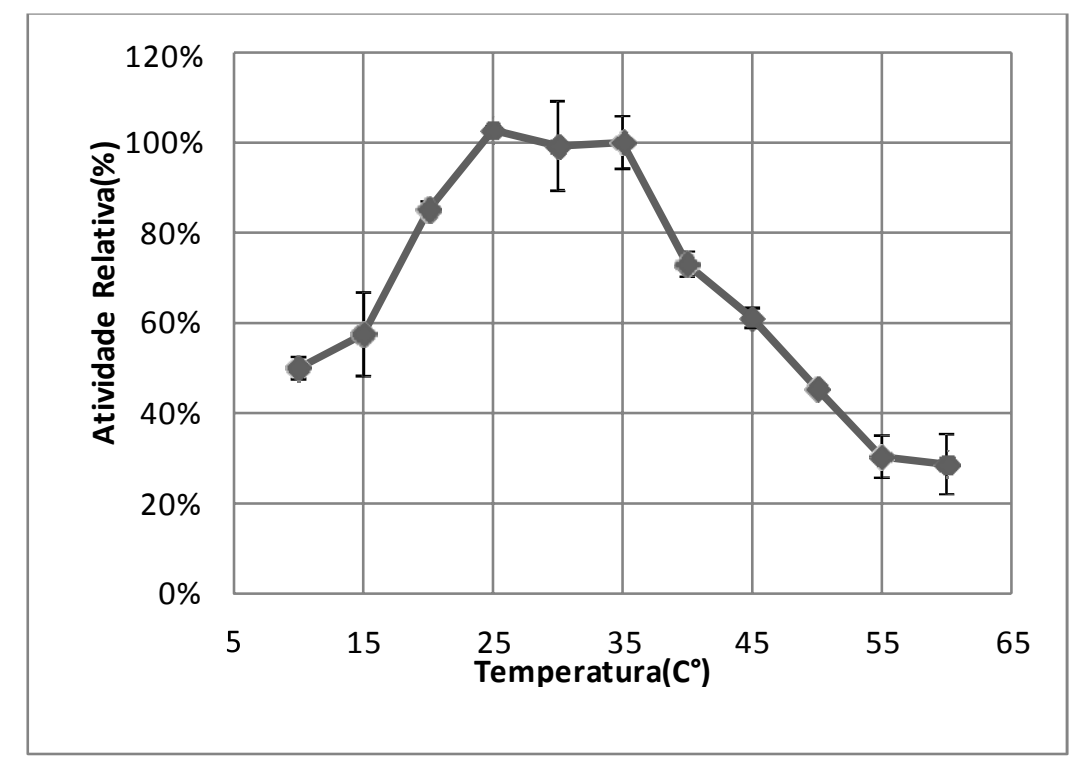

Figura 32-Gráfico da atividade relativa de TtGH62 em função da temperatura. A melhor temperatura para a enzima é em torno de $25^{\circ} \mathrm{C}$ A $35^{\circ} \mathrm{C}$.

Fonte: Elaborada pela autora.

Quando analisada a temperatura ótima de atividade, os maiores valores ficam num intervalo entre 25 e $35^{\circ} \mathrm{C}$, mostrando uma tolerância maior as variações térmicas. Esses dados estão dentro dos valores de $\mathrm{pH}$ e temperatura ótimos obtidos para outras GH62 com pNP-aAraF como substrato: Aspergillus fumigatus $\mathrm{pH} 4,5-5,0$ e $37-42^{\circ} \mathrm{C}$; (87) Podospora anserina pH 5,0 and $37 \stackrel{\circ}{\mathrm{C}}$; (62) Ustilago maydis $\mathrm{pH} 5,0$ e $37 \stackrel{\circ}{\circ}$ (62).

O painel de substrato mostrou a especificidade catalítica da TtGH62 frente a diferentes substratos. A enzima obteve máxima atividade quando em contato com o substrato arabinano, de acordo com o gráfico da Figura 33. Em segundo lugar com maior atividade em arabinoxilano de trigo (de alta e baixa viscosidade). Outros substratos demonstraram atividade muito baixa, abaixo de $10 \%$, que seriam xiloglucano e lichenano iceland moss. 


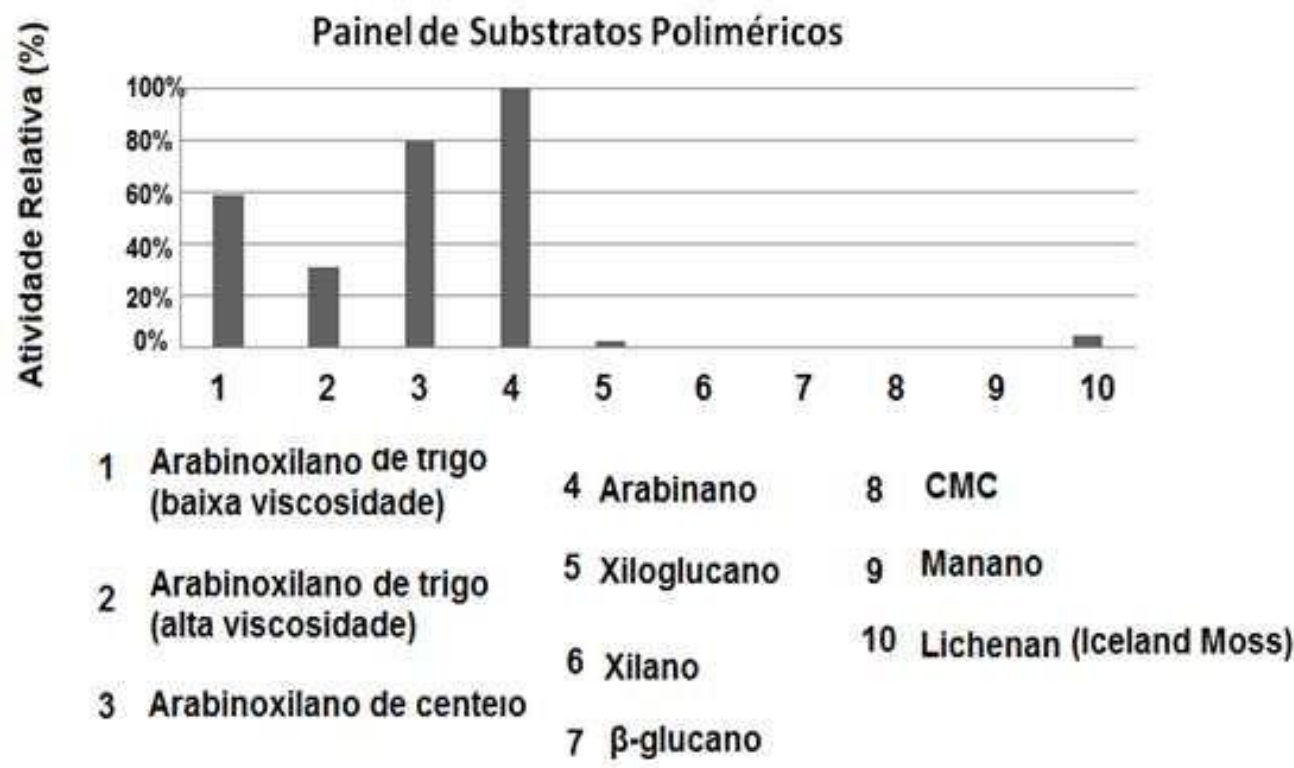

Figura 33-Gráfico comparando a atividade relativa da $T t G H 62$ a diferentes substratos poliméricos. Fonte: Elaborada pela autora.

A partir dos substratos que demonstraram maior atividade, foi investigado, separadamente, a velocidade da reação em função da concentração do substrato. Os dados contidos na Figura 34 mostram os gráficos com a relação entre a velocidade da reação e a concentração do substrato, sob as condições ótimas de atividade.

O valor de $K_{M}$ para $T$ GHH62 foi de aproximadamente $6,20 \pm 0,85 \mathrm{mg} / \mathrm{mL}$ em substrato de pNP- $\alpha A r a F, 2,50 \pm 0,77 \mathrm{mg} / \mathrm{mL}$ para arabinoxilano de trigo e 5,00 \pm $2,02 \mathrm{mg} / \mathrm{mL}$ para arabinano. Os valores de $\mathrm{k}_{\text {cat }}$ foram $372,85 \pm 8,35,376,95 \pm 25,48$ e 240,66 $\pm 13,39$ para pNP- $\alpha A$ AraF, arabinoxilano de trigo e arabinano respectivamente. Todos os dados citados estão na Tabela 6. 
Tabela 6 - Valores de $K_{\mathrm{M}}$ e $\mathrm{k}_{\text {cat }}$ para TtGH62 nos substratos pNP-aAraF, arabinoxilano de trigo e arabinano.

\begin{tabular}{|l|l|l|l|}
\hline Substrato & $k_{\mathrm{cat}} \pm \mathrm{SD}$ & $K_{m} \pm \mathrm{SD}$ & $k_{\mathrm{cat}} / K_{m}$ \\
\hline $\begin{array}{l}\text { pNP-a-l- } \\
\text { arabin ofuranoside o }\end{array}$ & $372,85 \pm 8,35\left(\mathrm{~min}^{-1}\right)$ & $6,23 \pm 0,85 \mathrm{mM}$ & $53,2\left(\mathrm{~min}^{-1} \cdot \mathrm{mM}^{-1}\right)$ \\
\hline Arabinoxilano de trigo & $376,95 \pm 25,48\left(\mathrm{~min}^{\prime}\right)$ & $2,57 \pm 0,77 \mathrm{mg} / \mathrm{mL}$ & $123,3\left(\mathrm{~min}^{\prime} \cdot \mathrm{mg} \cdot \mathrm{mL}\right)$ \\
\hline Arabinano & $240,66 \pm 13,39\left(\mathrm{~min}^{-1}\right)$ & $5,04 \pm 2.02 \mathrm{mg} / \mathrm{mL}^{-}$ & $48\left(\mathrm{~min}^{-1} \cdot \mathrm{mg}^{-1} \cdot \mathrm{mL}\right)$ \\
\hline
\end{tabular}

Fonte: Elaborada pela autora

Tomando por base esses valores de $\mathrm{pH}$ e temperatura ótimos, os parâmetros cinéticos da TtGH62 foram determinados nos substratos pNP-aAraF, arabinoxilano de trigo e arabinano, que representam os substratos onde a TtGH62 tiveram maiores atividades. Os valores de $\mathrm{K}_{\mathrm{M}}$ e $\mathrm{k}_{\text {cat }}$ representados na Tabela 5 mostram um número de renovação (turnovernumber) maior para o substrato arabinoxilano de trigo, que é também o substrato em que a enzima possui maior afinidade $\left(\mathrm{K}_{\mathrm{M}}=2,6 \pm 0,8 \mathrm{mg} / \mathrm{mL}\right)$, sendo o substrato comum a todas as $\mathrm{GH} 62$ caracterizadas.

Muitas enzimas são melhor compreendidas quando comparada com outras da mesma família, principalmente quando se trata de caracterização funcional. A melhor maneira de avaliar o desempenho enzimático de uma proteína é analisando os parâmetros cinéticos entre as enzimas de mesma classificação. Ao comparar o $\mathrm{k}_{\text {cat }} \mathrm{da}$ arabinofuranosidase de $T$. terrestris com outra arabinofuranosidase oriunda da bactéria Streptomyces thermoviolaceus, ambas pertencentes à família das GH62, nota-se que se encontram na mesma ordem de grandeza, mas quando o substrato é o pNP-aAraF, a diferença de número de renovação são duas ordens de grandeza maiores para a enzima TtGH62, possuindo quase o dobro de afinidade também. Isso sugere interações moleculares mais seletivas da enzima bacteriana aos substratos poliméricos, contrapondo uma natureza menos discriminatória para a enzima fúngica em comparação ao substrato sintético (Tabela 7 e Tabela 8). A TtGH62 apresenta afinidade em arabinano como também ocorre com SthAbf62A, no entanto, em menor proporção. Já em contato com o substrato pNP- $\alpha-\mathrm{I}-$ arabinopyranosideo há diferenças, pois TtGH62 não apresenta nenhuma atividade e SthAbf62A possui uma atividade mínima. (83) Todos os dados cinéticos de SthAbf62A estão na Figura 35 e Figura 35 e Tabela 8. 


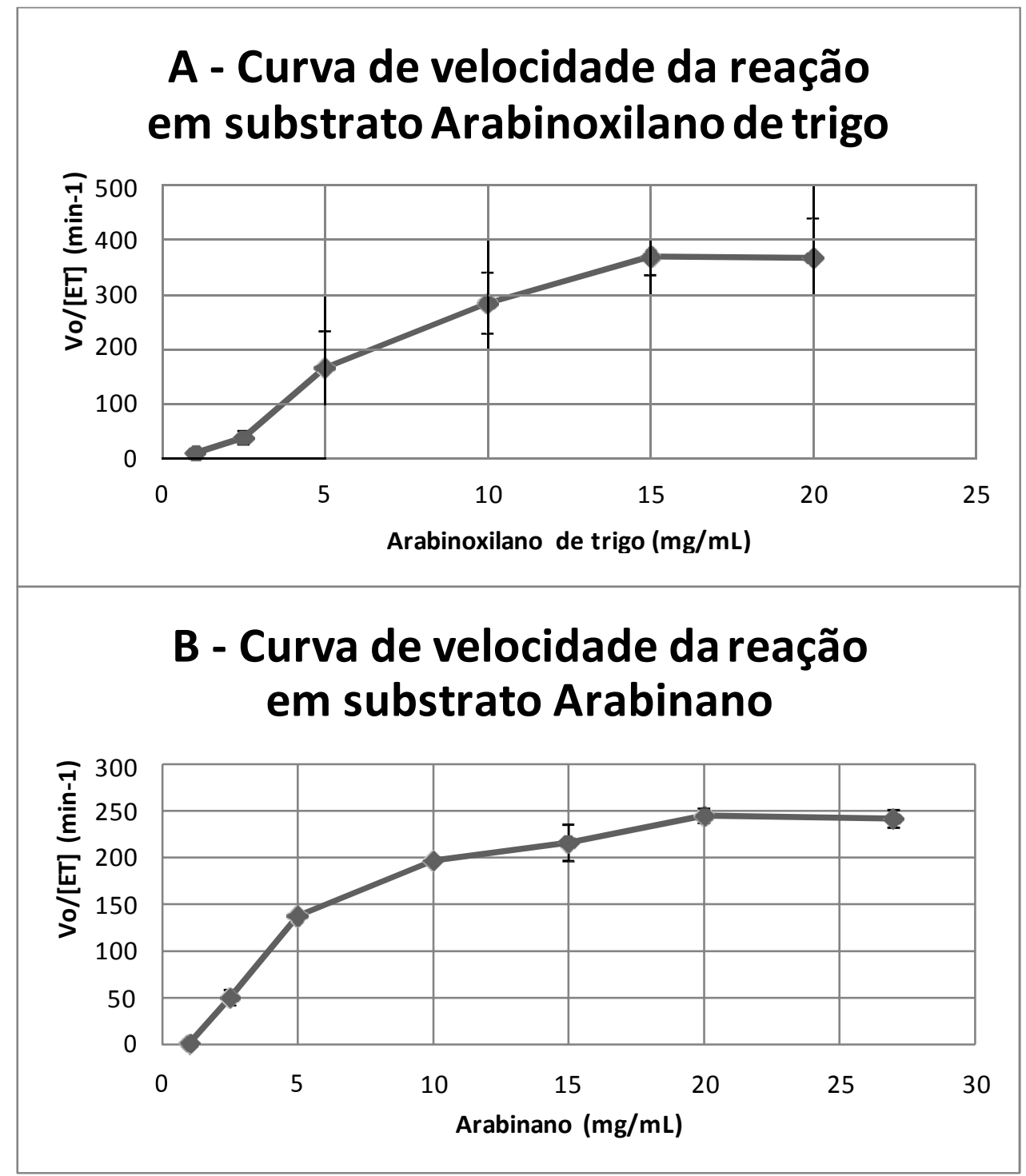

Figura 34- Gráficos medindo a velocidade da reação sob diferentes concentrações de substrato. A) Curva de Michaelis-Menten para TtGH62 utilizando Arabinoxilano de trigo como substrato. B) Curva de Michaelis-Menten para TtGH62 utilizando Arabinano como substrato.

Fonte: Elaborada pela autora. 

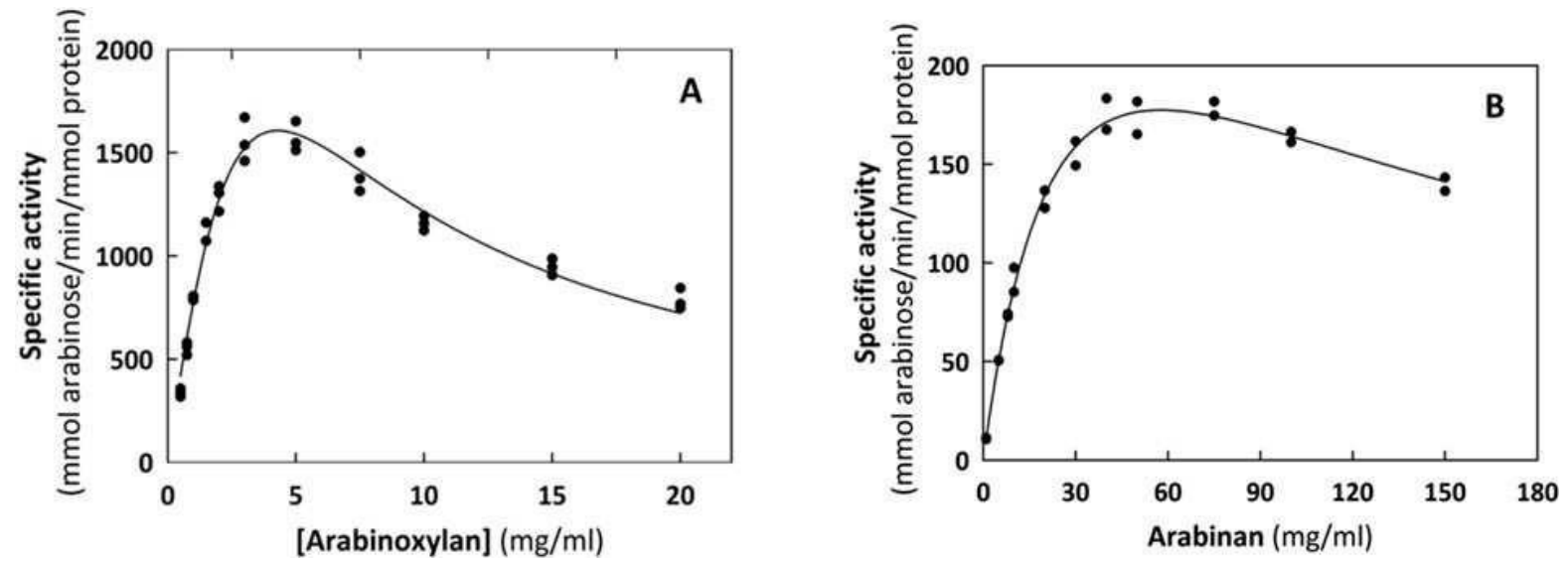

Figura 35 - Gráficos medindo a velocidade da reação sob diferentes concentrações de substrato.

A) Curva de Michaelis-Menten para SthAbf62A utilizando Arabinoxilano de trigo como substrato. B) Curva de Michaelis-Menten para SthAbf62A utilizando Arabinano como substrato.

Fonte: WANG et al. (83)

Tabela 7-Valores de $\mathrm{K}_{\mathrm{M}}$ e $\mathrm{K}_{\mathrm{cat}}$ para SthAbf62A nos substratos pNP- $\alpha$ AraF, arabinoxilano de trigo $\mathrm{e}$ arabinano.

\begin{tabular}{|l|l|l|l|}
\hline Substrato & $k_{\text {cat }}\left(\mathrm{s}^{-1}\right) \pm \mathrm{SD}$ & $K_{m} \pm \mathrm{SD}$ & $K_{\mathrm{cat}} / K_{m}$ \\
\hline $\begin{array}{l}\text { pNP- } \alpha-I- \\
\text { arabinofuranosideo }\end{array}$ & $1,3 \pm 0,1$ & $3,0 \pm 0,1(\mathrm{mM})$ & $0,5\left(\mathrm{~s}^{-1} \cdot \mathrm{mM}^{-1}\right)$ \\
\hline Arabinoxilano de trigo & $180 \pm 65$ & $12 \pm 5(\mathrm{mg} / \mathrm{mL})$ & $15\left(\mathrm{~s}^{-1} \cdot \mathrm{mg}^{-1} \cdot \mathrm{mL}\right)$ \\
\hline Arabinano & $6,0 \pm 0,5$ & $32 \pm 4,3(\mathrm{mg} / \mathrm{mL})$ & $0,2\left(\mathrm{~s}^{-1} \cdot \mathrm{mg}^{-1} \cdot \mathrm{mL}\right)$ \\
\hline
\end{tabular}

Fonte: WANG et al. (83)

Tabela 8-Comparação dos parâmetros cinéticos de TtGH62 e SthAbf62A em substratos pNP- $\alpha$ AraF, arabinoxilano de trigo e arabinano.

\begin{tabular}{|c|c|c|c|c|c|c|}
\hline & \multicolumn{3}{|l|}{ TtGH62 } & \multicolumn{3}{|l|}{ SthAbf62A } \\
\hline Substrato & pNP- $\alpha$ AraF & Arabinoxilano & Arabinano & pNP- $\alpha$ AraF & Arabinoxilano & Arabinano \\
\hline Kcat (s -1) & $6,2 \pm 0,8$ & $6,3 \pm 0,2$ & $4 \pm 0,1$ & $1.3 \pm 0.003$ & $180 \pm 65$ & $6 \pm 0.5$ \\
\hline $\mathrm{Km}$ & $\begin{array}{lll}6,2 & \pm & 0,8 \\
\mathrm{mM} & & \end{array}$ & $\begin{array}{lcc}2,6 \quad \pm & 0,8 \\
m g \cdot \mathrm{mL}^{-1} & \end{array}$ & 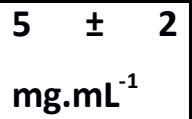 & $\begin{array}{l}3 \pm \\
\mathrm{mM}\end{array}$ & $\begin{array}{l}12 \pm 5 \\
\mathrm{mg} \cdot \mathrm{mL}^{-1}\end{array}$ & $\begin{array}{l}32 \pm 4.3 \\
\mathrm{mg} \cdot \mathrm{mL}^{-1}\end{array}$ \\
\hline
\end{tabular}

Fonte: Elaborada pela autora. 


\subsection{MUTAÇÕES SÍTIO DIRIGIDAS}

As mutações foram feitas de acordo com os oligonucleotídeos contidos na Tabela 9, todos com temperaturas de melting (TM) em torno de $66{ }^{\circ} \mathrm{C}$. As 4 mutações são de acordo com a localização do sítio ativo e ponte dissulfeto, as quais foram trocadas por um resíduo de Alanina.

Tabela 9-Tabela contendo os oligonucleotídeos utilizados nos ensaios de mutação sítio dirigida.

\begin{tabular}{l|l|l}
\hline Oligonucleotídeo & Sequência & Temperatura de Melting \\
\hline ASP58_fw (foward) & CCAAAGAACGGCGGGACCTCGCT & $66,8^{\circ} \mathrm{C}$ \\
ASP58_rv (reverse) & TGCGCCAACGCACCGGTCGAATT & $66^{\circ} \mathrm{C}$ \\
ASP165_fw(foward) & GGGCGTCATCGCGCAGACCGTCA & $68^{\circ} \mathrm{C}$ \\
ASP165_rv(reverse) & GTGCTGGAACCTGAGATCGTGCC & $62^{\circ} \mathrm{C}$ \\
GLU217_fw(foward) & CAACCTGTTCGCGGCCGTGCAGG & $67,4^{\circ} \mathrm{C}$ \\
GLU217_rv(reverse) & TTGGTCGAGTCGCTCATGACGAC & $61^{\circ} \mathrm{C}$ \\
CYS300_fw(foward) & CGTCGACCCCGCGAACCTGCAGC & $68,8^{\circ} \mathrm{C}$ \\
CYS300_rv(reverse) & GTCATGGTCTGGTCGTTGGTGAC & $66^{\circ} \mathrm{C}$ \\
\hline
\end{tabular}

Fonte: Elaborada pela autora. 


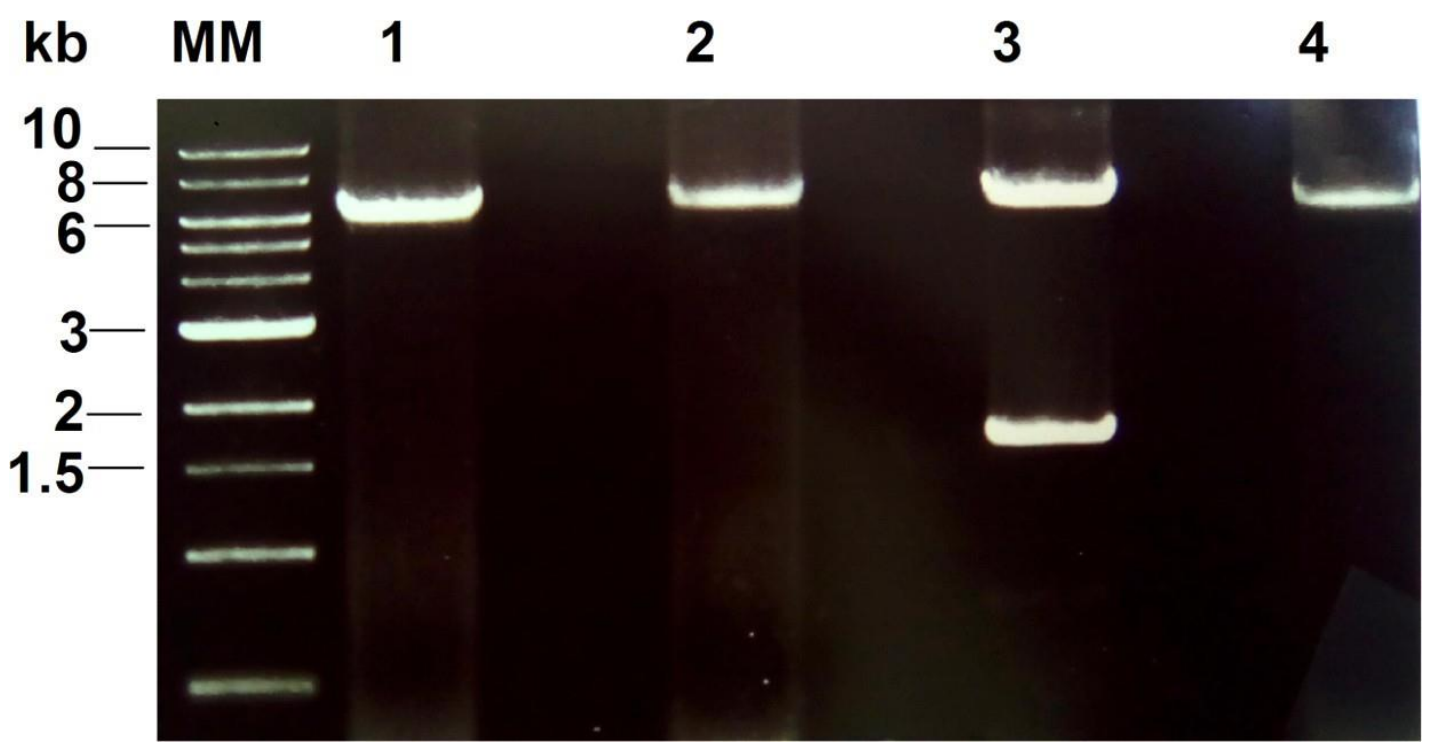

Figura 36-Imagem do gel de agarose $0,8 \%$ após eletroforese. Resultado da reação de primers com vetor, com as amostras amplificadas. 1) Clone contendo a mutação ASP58. 2) Clone contendo a mutação Asp165. 3) Clone contendo a mutação Glu217. 4) Clone contendo a mutação Cys300.

Fonte: Elaborada pela autora.

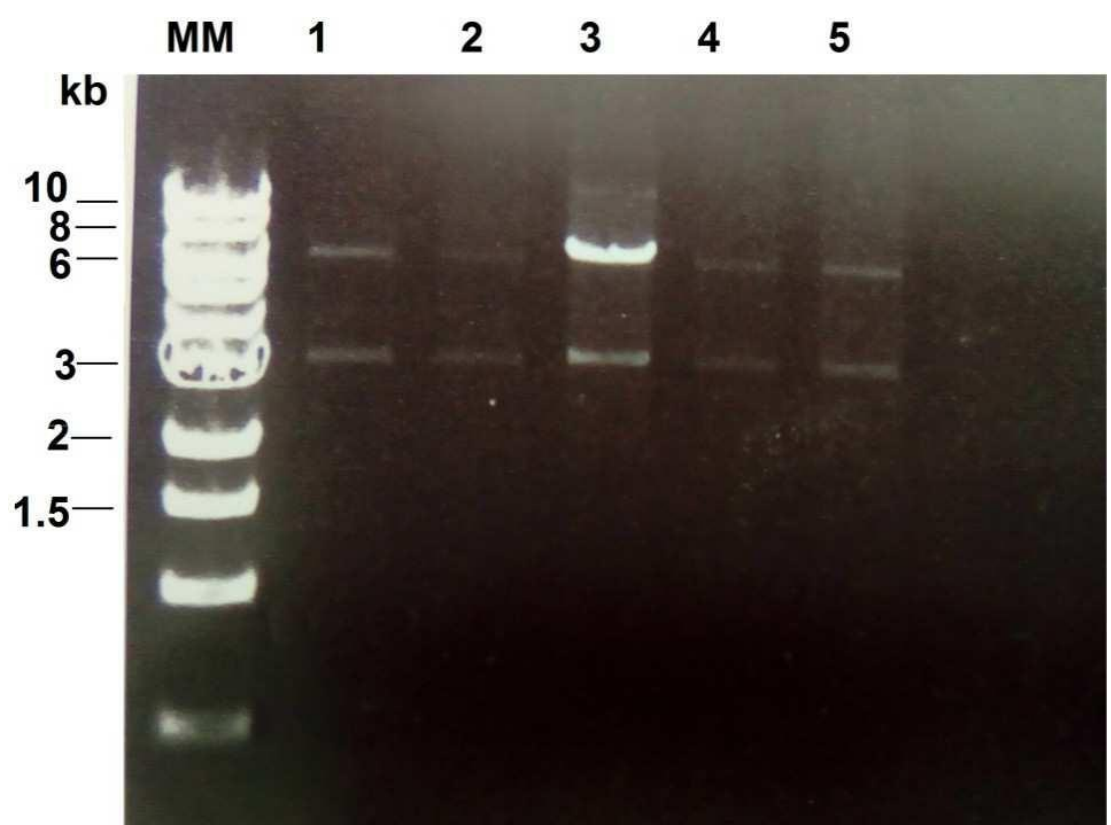

Figura 37 - Imagem do gel de agarose $0,8 \%$ após eletroforese. Resultado do ensaio de PCR de colônia contendo 5 amostras referentes aos clones Asp58 e Cys300. 1,2) Clone com mutação Asp58. 3,4,5) Clone com mutação Cys300. As amostras estão localizadas no peso de aproximadamente $7 \mathrm{~kb}$, o que corresponde ao peso do vetor $(6.800 \mathrm{pb})$.

Fonte: Elaborada pela autora. 
As Figura 36 e Figura 37 mostram os géis de agarose após a eletroforese horizontal das amostras após amplificação dos genes. A banda de 6 confirma que 0 vetor se encontra no tamanho ideal (aproximadamente 6,7 pb). A reação em cadeia da polimerase a partir de 6 colônias confirmou 5 colônias positivas referentes aos clones 1 e 4 (Figura 37). Os demais não foram confirmados através dessa técnica, apenas pela seletividade fornecida pelos antibióticos. No entanto, é importante lembrar que a técnica de PCR de colônia não é fator determinante para confirmar um plasmídeo recombinante, pois não é necessário que todas as bases coincidam com o primer, e no caso foi alterada apenas uma base. Muitas vezes a reação pode não ocorrer devido a temperatura de anelamento estar acima ou abaixo do necessário, ou outros fatores pertinentes ao meio reacional. Portanto, o que de fato confirma o clone é a expressão da proteína de interesse e um sequenciamento do plasmídeo. O PCR de colônia apenas indica que o inserto foi de fato inserido na bactéria.

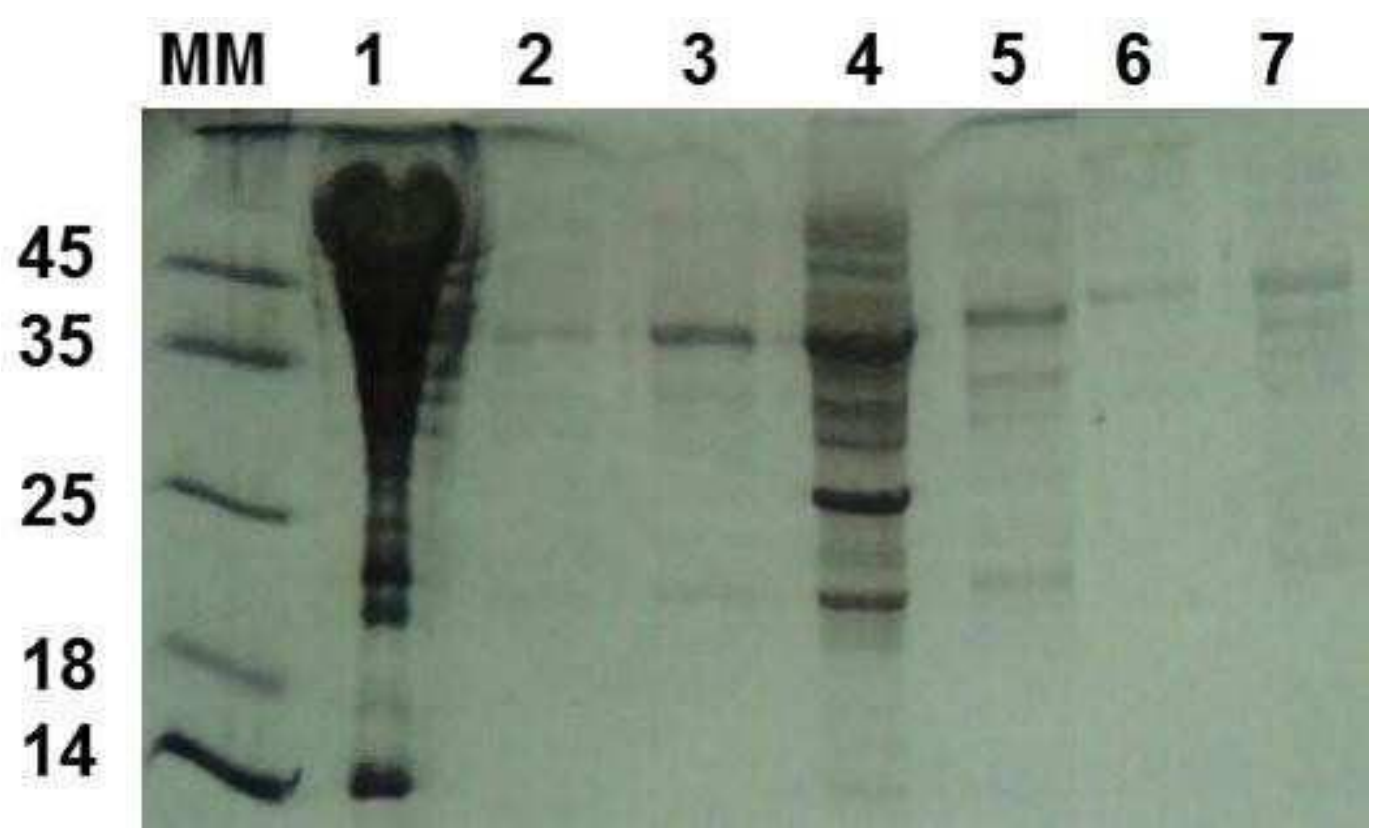

Figura 38 - Gel SDS-PAGE 15\% com as amostras das proteínas heterólogas mutantes, sendo mutante 1 referente a mutação Asp58, mutante 2 referente a mutação Asp165, mutante 3 referente a mutação Glu217 e mutante 4 referente a mutação Cys300. MM) Marcador de massa molecular. 1) Extrato bruto do selvagem. 2) Mutante 1 após purificações. 3) Mutante 2 após purificações. 4) Mutante 1 antes da purificação. 5) Mutante 3 após purificações. 6) Selvagem após purificações. 7) Mutante 4 após purificações.

Fonte: Elaborada pela autora. 
As proteínas mutantes foram purificadas em duas etapas, a primeira utilizando coluna com resina de níquel (cromatografia por afinidade) e depois uma coluna HiLoad 16/60 Superdex 75 (GE Healthcare) (cromatografia de exclusão por tamanho molecular). No entanto, devido a linhagem de expressão bacteriana ser diferente da selvagem, os clones apresentaram uma menor produção de proteína (cerca de $2 \mathrm{mg} / \mathrm{mL}$ ) por litro. Além disso, notou-se uma maior dificuldade em se obter uma amostra pura devido a maior quantidade de contaminantes. A Figura 38 mostra os mutantes após as purificações em comparação com o selvagem. A Figura 39 possui os mutantes antes da purificação e clivagem com TEV protease, portanto todos se encontram na faixa de $45 \mathrm{kDa}$. Os mutantes foram submetidos ao teste de atividade enzimática, no entanto foi constatado nenhuma atividade.

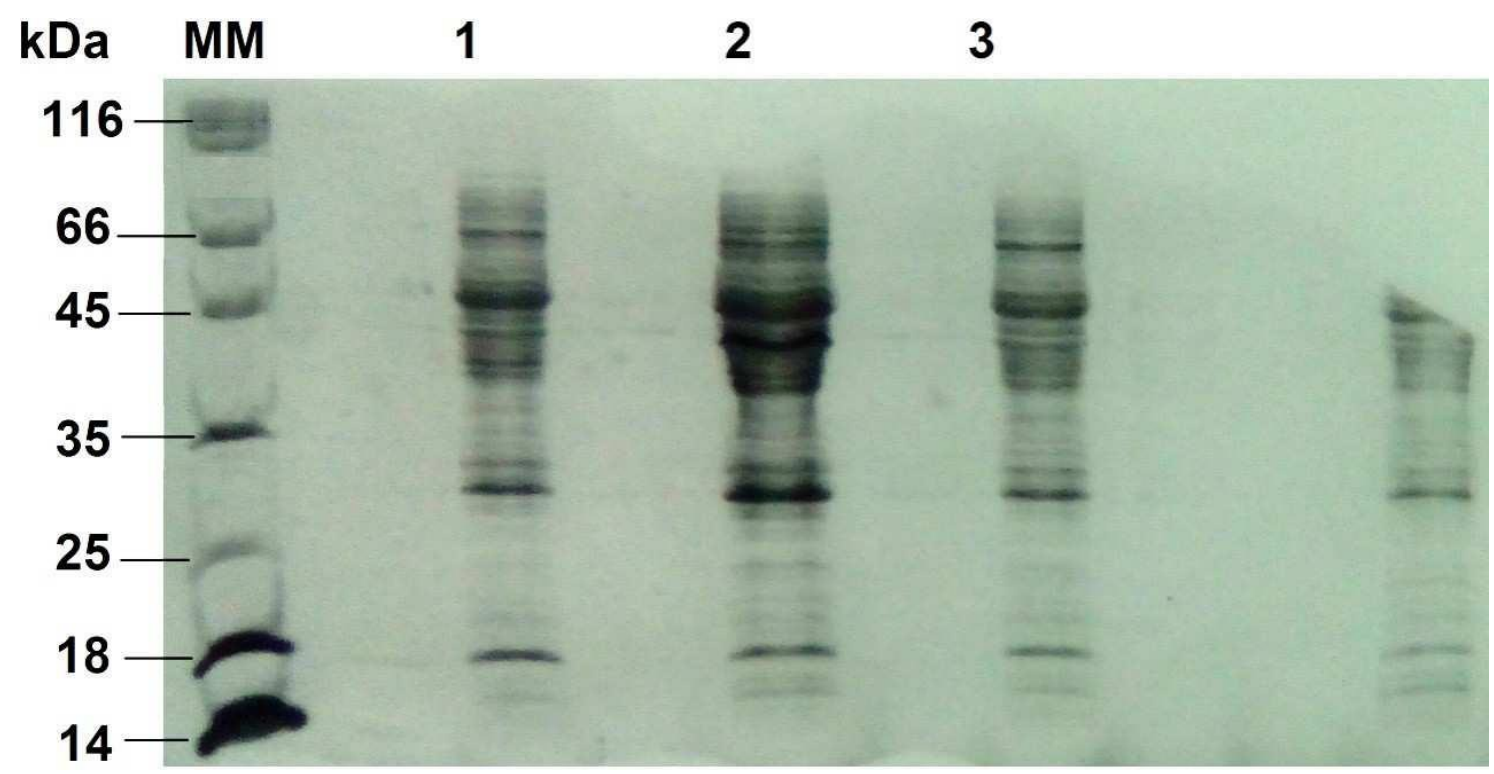

Figura 39 - Gel SDS-PAGE 15\% com as amostras de proteínas mutantes. 1) Mutante referente a mutação Asp165. 2) Mutante referente a mutação Glu217. 3) Mutante referente a mutação Cys300.

Fonte: Elaborado pela autora. 


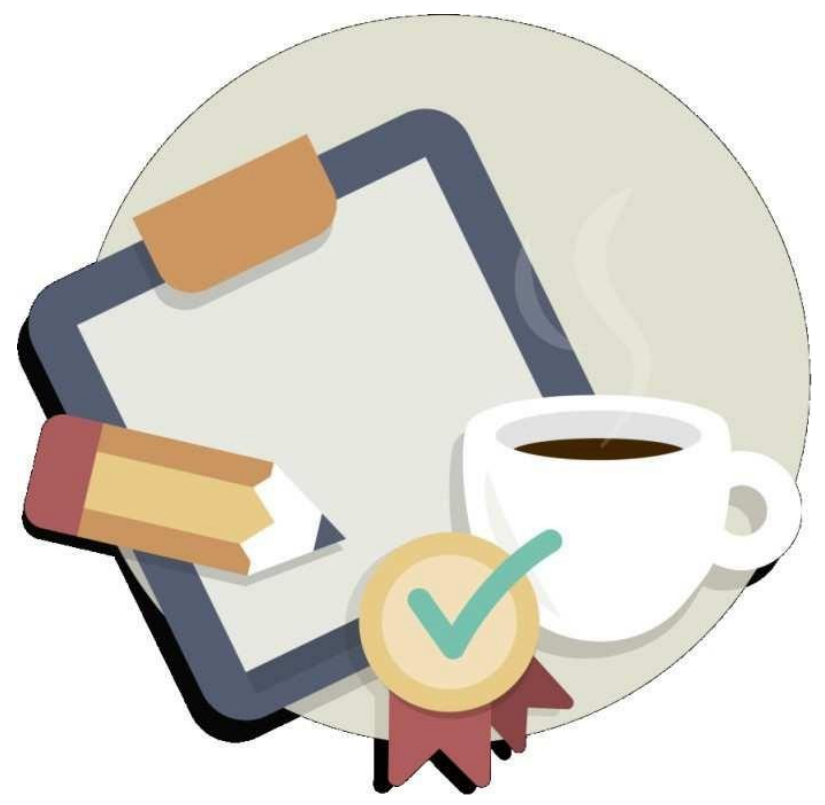

\section{CONCLUSÕES EPERSPECTIVAS}

O alinhamento das sequências das familias de hidrolase de glicosídeos (GH) 32, 43, 62 e 68 mostra blocos conservados (alinhamentos em anexos), contendo um resíduo ácido e outro resíduo básico. Maiores análises a partir de experimentos com mutações sítio dirigidas revelam que as proteínas da familia GH32, GH43, GH68 e GH62 possuem resíduos conservados Asp/Glu na ligação ao substrato e hidrólise. Os resíduos catalíticos estão próximos do espaço entre as "pás" da estrutua de beta-propeller. A arquitetura em beta-propeller segue um padrão, sendo que a junção de lâminas $\mathrm{C}$ e $\mathrm{N}$ terminal formam um círculo, gerando alta estabilidade proteica também conferida pela ponte dissulfeto que une o "velcro molecular". No entanto, a estrutura aqui demonstrada é uma controvérsia a essas informações, já que a mesma possui um domain swapping gerando um dímero que se estabiliza principalmente por uma ponte dissulfeto.

O motivo conservado SHG (Serina-Histidina-Glicina), costuma localizar-se na parte inferior do sítio catalítico envolvendo assim o íon cálcio, que se encontra ligado à histidina e moléculas de água. (62) No entanto, na estrutura de TtGH62 isso não ocorre, pois o motivo SHG (Serina-Histidina-Glicina) se encontra nas extremidades superiores dos dímeros. Todas essas análises concluem que a 
estrutura quaternária da enzima é em forma de tetramero, pois a interdependência entre os sítios (causada pela complementariedade dos mesmos) só é possível nessa arquitetura molecular. Portanto, o fenômeno de domain swapping revela uma nova estrutura dentro das GH62 e sugere novas especificidades aos substratos.

Os mutantes feitos com a ajuda do professor Rolf A. Prade na Oklahoma State University foram expressos e constatou a presença da proteína mutante. No entanto, maiores ensaios para averiguar os mutantes devem ser feitos. $O$ sequenciamento dos plasmídeos recombinantes seria fundamental para a confirmação definitiva dos clones. As proteínas mutantes também devem ser investigadas em relação à estrutura, pois uma delas é referente à ponte dissulfeto. A ponte dissulfeto existente na estrutura proteica é única e estabiliza a estrutura quaternária, portanto, com a ausência da mesma, pressupõe que a estrutura mude de identidade.

De acordo com o conceito de energia livre para domain swapping (86), que explica que a interface de um monômero fechado é interceptada quando exposta a certas condições que causariam a quebra do monômero, o que diferencia sua energia de ativação. Existe a interação entre dois monômeros abertos que geram o dímero com domain swapping, com pouca diferença na energia livre, já que ambos possuem as mesmas estruturas. Há maior diferença de energia livre entre 0 monômero fechado e a estrutura gerada a partir do domain swapping, que pode ser explicada através de alguns processos, tais como: alterações de $\mathrm{pH}$ e temperatura, agentes mutantes e desnaturantes. Portanto, o modelo energético que favorece 0 domain swapping é condicionado por essas mudanças de condição. Além disso, um loop de articulação poderia gerar novas interações para o dímero, alterando, assim, o equilibrio entre o tetrâmero com o domain swapping e o dímero (78). As condições fisiológicas do organismo de origem da proteína são $\mathrm{pH}$ ácido e alta temperatura (45 $\left.{ }^{\circ} \mathrm{C}\right)$, proporcionando-nos uma base para acreditar que $\mathrm{O}$ novo arranjo molecular da enzima foi criado a partir de alterações moleculares causadas pelas condições ambientais e fisiológicas.

Logo, maiores investigações são necessárias para detalhar o comportamento da proteína estudada e assim ajudar a compreender melhor a família das GH62. 


\section{REFERÊNCIAS}

1 KOHLHEPP, G. Análise da situação da produção de etanol e biodiesel no Brasil. Estudos Avançados, v. 24, n. 68, p. 223-253, 2010.

2 BUCKERIDGE, M. S.; DE SOUZA, A. P. Routes to second-generation bioethanol in Brazil: foundation of the National Institute of Science and Technology of Bioethanol. In: BUCKERIDGE, M. S. et al. Advances of basic science for second generation bioethanol from sugarcane.Berlin: Springer International Publishing, 2017. p. 1-4.

Disponivel em: <https://www.slideshare.net/Bioetanol/wks-hydrolysis-marcos-sbuckeridge-usp-cell-wall-degradation>.Acesso em: 01 maio 2018.

3 MACEDO, I.C. et al. Biocombustíveis. Parcerias Estratégicas, 2010, 9.19: 255288.

4DURÃES, F. O. M. Biocombustíveis reais questões para a equação Brasil de desenvolvimento sustentável. Revista de Política Agrícola, 2008, 17.1: 129-131.

5DA ROSA, S. E. S.; GARCIA, J. L. F. O etanol de segunda geração: limites e oportunidades. Revista do BNDES, v. 32, p. 118, 2009.

6 SANTOS, J. A.; FERREIRA FILHO, J. B. S. Substituição de combustíveis fósseis por etanol e biodiesel no Brasil e seus impactos econômicos: uma avaliação do plano nacional de energia 2030.2017. Disponível em: $<$ http://repositorio.ipea.gov.br/handle/11058/8231>. Acesso em 11 jan. 2017

7BRASIL. Ministério de Minas e Energia. Agência Nacional do Petróleo, Gás Natural e Biocombustíveis.Dados estatísticos - produção de biocombustíveis. 2016. Disponível em: <http://www.anp.gov.br/wwwanp/dados-estatisticos>. Acesso em 12 maio 2017.

8MOTTA, G. P. O. Análise de alternativas e impactos para substituição do diesel por etanol no processo de produção sucroalcooleiro.2011, 190 p. Trabalho de Conclusão de Curso (Engenharia de Produção) - Escola Politécnica, Universidade de São Paulo, São Paulo, 2011.

9 SOCCOL, C. R. et al. Bioethanol from lignocelluloses: status and perspectives in Brazil. Bioresource Technology, v. 101, n. 13, p. 4820-4825, 2010.

10 RODRIGUES, D.; ORTIZ, L. Em direção à sustentabilidade da produção de etanol de cana de açúcar no Brasil. 2006. Disponível em: $<$ http://www.ecoa.org.br/arquivos/444052181.pdf>. Acesso em 10 jul. 2017.

11 ROOT, T. L. et al. Fingerprints of global warming on wild animals and plants. Nature, v. 421, n. 6918, p. 57, 2003.

12 NOGUEIRA, L. A. H.; LORA, E. S. Dendroenergia: fundamentos e aplicações. 2 ed. Rio de Janeiro: Interciência, 2003. 
13 PRADE, R. A. Xylanases: from biology to biotechnology. Biotechnology and Genetic Engineering Reviews, v. 13, n. 1, p. 101-132, 1996.

14 GUPTA, A. et al. Sustainable bio-ethanol production from agro-residues: a review. Renewable and Sustainable Energy Reviews, v. 41, p. 550- 567, 2015.doi.org/10.1016/j.rser.2014.08.032

15 BRASIL. Ministério da Agricultura, Pecuária e Abastecimento. Companhia Nacionalde Abastecimento. Acompanhamentodasafra brasileira cana-de-açúcar. primeiro levantamento - safra 2016/17. 2016. Disponível em:<https://www.conab.gov.br/info-agro/safras/cana/boletim-da-safra-de-cana-deacucar/item/download/1207_fe77c3da032b7129606ffde03f820789>. Acesso em 18 fev. 2018.

16 BRASIL. Ministério de Planejamento e Desenvolvimento Energético. Resenha energética brasileira, junho de 2016. Disponível em:

<http://www.mme.gov.br/documents/10584/3580498/02++Resenha+Energ\%C3\%A 9tica+Brasileira+2017+-+ano+ref.+2016+\%28PDF\%29/13d8d958-de50-4691-96e33ccf53f8e1e4?version=1.0>. Acesso em 11 fev.2017

17 PEREIRA, S. C. et al. Physical-chemical-morphological characterization of the whole sugarcane lignocellulosic biomass used for $2 \mathrm{G}$ ethanol production by spectroscopy and microscopy techniques. Renewable Energy, v. 87, Pt. 1, p. 607617, 2016.

18 SÃO PAULO (Estado)União da Indústria de Cana-deAçúcar.Setorsucroenergético apresenta resultados positivos na geração de empregos no mês de março. 2016. Disponível em:

<http://www.unica.com.br/noticia/29063662920315624493/setor-sucroenergeticoapresenta-resultados-positivos-na-geracao-de-emprego-no-mes-de-marco/>. Acesso em 11 fev.2017

19 DIAS, M. O. S. et al.Second generation ethanol in Brazil: can it compete with electricity production?.Bioresource Technology, v. 102, n. 19, p. 8964-8971, 2011.

20 GUERRA, S. M. G.; GONZALEZ, M. P. Novas trajetórias energéticas.Santo André: EUMED, 2009.

21 OGEDA, T. et al. Hidrólise enzimática de biomassa. Química Nova, v. 33, n. 7, p. 1549-1558, 2010.

22 GOLDBECK, R. et al. Effect of hemicellulolytic enzymes to improve sugarcane bagasse saccharification and xylooligosaccharides production. Journal of Molecular Catalysis B: enzymatic, v. 131, p. 36-46, 2016.doi.org/10.1016/.jmolcatb.2016.05.013

23 O'SULLIVAN, A. C. Cellulose: the structure slowly unravels. Cellulose, v. 4, n. 3, p. 173-207, 1997. 
24 ATALLA, R. H. et al. Hemicelluloses as structure regulators in the aggregation of native cellulose. International Journal of Biological Macromolecules, v. 15, n. 2, p. 109-112, 1993.

25 UHLIG, H.; BEDNAR, E. M. L. Industrial enzymes and their applications.New York: Wiley-Interscience, 1998. 454p.

26 SILVA, N. L. C. Produção de bioetanol de segunda geração a partir de biomassa residual da indústria de celulose. 2010. 109 p. Dissertação (Mestrado em Tecnologia de Processos Químicos e Bioquímicos) - Universidade Federal do Rio de Janeiro, Rio de Janeiro, 2010.

27 DEBOY, R. T. et al. Insights into plant cell wall degradation from the genome sequence of the soil bacterium Cellvibrio japonicus. Journal of Bacteriology, v. 190, n. 15, p. 5455-5463, 2008.

28 ALVIRA, P. et al. Pretreatment technologies for an efficient bioethanol production process based on enzymatic hydrolysis: a review. Bioresource technology, 2010, 101.13: 4851-4861.

29 MOSIER, N. et al. Features of promising technologies for pretreatment of lignocellulosic biomass.Bioresource Technology, v. 96, n. 6, p. 673-686, 2005.

30 TAHERZADEH, M. J.; KARIMI, K. Pretreatment of lignocellulosic wastes to improve ethanol and biogas production: a review. International Journal of Molecular Sciences, v. 9, n. 9, p. 1621-1651, 2008.

31 BAJPAI, P. Application of enzymes in the pulp and paper industry. Biotechnology Progress, v. 15, n. 2, p. 147-157, 1999.

32 VIIKARI, L. et al. Xylanases in bleaching: from an idea to the industry. FEMSMicrobiologyReviews, v. 13, n. 2-3, p. 335-350, 1994.

33 MARTINEZ-ANAYA, M. A.; JIMÉNEZ, T. Functionality of enzymes that hydrolyse starch and non-starch polysaccharide in breadmaking. Zeitschrift für Lebensmitteluntersuchung und-Forschung A, v. 205, n. 3, p. 209-214, 1997

34 GOBBETTI, M. et al. Arabinose fermentation by Lactobacillus plantarum in sourdough with added pentosans and $\alpha$-L-arabinofuranosidase: a tool to increase the production of acetic acid. Journal of Applied Microbiology, v. 88, n. 2, p. 317324, 2000.

35 BEZALEL, L.; SHOHAM, Y.; ROSENBERG, E. Characterization and delignification activity of a thermostable $\alpha$-L-arabinofuranosidase from Bacillus stearothermophilus. Applied Microbiology and Biotechnology, v. 40, n. 1, p. 5762, 1993. 
36 MARTINEZ-ANAYA, M. A. et al. Effects of the combination of starters and enzymes in regulating bread quality and shelf life/effectos de la combinación de iniciadores microbianos y enzimas en la calidad y conservación del pan. Food Science and Technology International, v. 5, n. 3, p. 263-273, 1999.

37 GOBBETTI, M. et al. Added pentosans in breadmaking: fermentations of derived pentoses by sourdough lactic acid bacteria. Food Microbiology, v. 16, n .4, p. 409418, 1999.

38 FESSAS, D.; SCHIRALDI, A. Texture and staling of wheat bread crumb: effects of water extractable proteins andpentosans'. Thermochimica Acta, v. 323, n. 1-2, p. 17-26, 1998.

39 WHITAKER, J. R. Pectic substances, pectic enzymes and haze formation in fruit juices. Enzyme and Microbial Technology, v. 6, n. 8, p. 341-349, 1984.

40 ERGÜN, B. G.; ÇALIK, P. Lignocellulose degrading extremozymes produced by Pichia pastoris: current status and future prospects. Bioprocess and Biosystems Engineering, v. 39, n. 1, p. 1-36, 2016.

41 SINGH, R. P.; HELDMAN, D. R. Introduction to food engineering. New Jersey: Wiley-Blackwell, 2015.

42 SARRY,J-E.; GÜNATA, Z. Plant and microbial glycoside hydrolases: volatile release from glycosidic aroma precursors. Food Chemistry, v. 87, n. 4, p. 509-521, 2004.

43 GUNATA, Z. et al. Sequential enzymic hydrolysis of potentially aromatic glycosides from grape. CarbohydrateResearch, v. 184, p. 139-149, 1988.doi.org/10.1016/0008-6215(88)80012-0

44 WINTERHALTER, P.; SKOUROUMOUNIS, G. K. Glycoconjugated aroma compounds: occurrence, role and biotechnological transformation. In: Berger R.G. et al.(Ed.)Biotechnologyofaroma compounds. Berlin: Springer, 1997. p. 73-105. (Advances in biochemical engineering/biotechnology, v. 55).

45 BELDMAN, G. et al. Arabinans and arabinan degrading enzymes. In: STURGEON, R.J. (Ed.) Advances in macromolecular carbohydrate research.London: JAI Press Inc, 1997, p. 1-64.

46 KORMELINK, F. J. M; GRUPPEN, H.; VORAGEN, A. G. J. Mode of action of $(1 \rightarrow$ 4)- $\beta$-d-arabinoxylan arabinofuranohydrolase $(\mathrm{AXH})$ and $\mathrm{ga}=\mathrm{I}-$ arabinofuranosidases on alkali-extractable wheat-flour arabinoxylan. Carbohydrate Research, v. 249, n. 2, p. 345-353, 1993.

47 WEAVER, J.; et al. Genetic analysis of a locus on the Bacteroides ovatus chromosome which contains xylan utilization genes.Applied and Environmental Microbiology, v.58, n. 9, p.2764-2770, 1992. 
48 GAN, Q.; ALLEN, S. J.; TAYLOR, G. Design and operation of an integrated membrane reactor for enzymatic cellulose hydrolysis.Biochemical Engineering Journal, v.12, n. 3, p.223-229, 2002.

$49 \mathrm{STORCH}, \mathrm{T}$. T. et al. Ethylene-dependent regulation of an $\alpha-\mathrm{I}-$ arabinofuranosidase is associated to firmness loss in 'Gala'apples under long term cold storage. Food Chemistry, v. 182, p. 111-119, 2015.doi: 10.1016/j.foodchem.2015.02.123.

50 SAHA, B. C. a-L-Arabinofuranosidases: biochemistry, molecular biology and application in biotechnology. Biotechnology Advances, v. 18, n. 5, p. 403-423, 2000.

51 GÜBITZ, G. M.; HALTRICH, D.; LATAL, B.; STEINER, W. Mode of depolymerization of hemicellulose by various mannanases and xylanases in relation to their ability to bleach softwood pulp. Applied Microbiology and Biotechnology, v.47, n. 6, p.658-621, 1997.

52 NELSON, D. L.; LEHNINGER, A. L.; COX, M. M. Lehninger principles of biochemistry. 6th ed. Basingstoke: MacmillanEducation, 2013.

53 GODFREY, T.; REICHELT, J. R. Introduction to industrial enzymology. New York: Nature Press,1983.

54 PANDEY, A et al. Enzyme technology. New Delhi: Springer Science \& Business Media, 2006.

55 GILBERT, M. et al. Characterization of the enzymes present in the cellulase system of Thielavia terrestris 255B. Bioresource Technology, v. 39, n. 2, p. 147153, 1992.

56 BERKA, R. M. et al. Comparative genomic analysis of the thermophilic biomassdegrading fungi Myceliophthora thermophila and Thielavia terrestris. Nature Biotechnology, v. 29, n. 10, p. 922, 2011.

57 GARDNER, J. A. F et al.The influence of extractives on the pulping of wood. In: HILLIS, W. E. (Ed.). Wood extractives and their significance to the pulp and paper industries. New York: Academic Press, 1962. p. 367-403.

58 SAMSON, R. A.; MAHMOOD, T.The genus Acrophialophora (Fungi, Moniliales). Acta Botanica Neerlandica, v. 19, n. 6, p. 804-808, 1970.

59 HALTRICH, D. et al. Production of fungal xylanases. Bioresource Technology, v. 58, n. 2, p. 137-161, 1996.

60 DE VRIES, R. P.; VISSER, J. Aspergillus enzymes involved in degradation of plant cell wall polysaccharides. Microbiology and Molecular Biology Reviews, v. 65 , n. 4, p. 497-522, 2001. 
61 GRAY, K. A.; ZHAO, L.; EMPTAGE, M. Bioethanol. Current Opinion in Chemical Biology, v. 10, n. 2, p. 141-146, 2006.

62 SIGUIER, B. et al.First structural insights into $\alpha$-L-arabinofuranosidases from the two GH62 glycoside hydrolase subfamilies.Journal of Biological Chemistry, v. 289, n. 8, p. 5261-5273, 2014.

63 CONTESINI, F. J. et al. Structural and functional characterization of a highly secreted $\alpha$-l-arabinofuranosidase (GH62) from Aspergillus nidulans grown on sugarcane bagasse.Biochimica et Biophysica Acta (BBA)-proteins and proteomics, v. 1865, n. 12, p. 1758-1769, 2017.

64 GIACOVAZZO, C. et al. Fundamentals of crystallography.Oxford: Oxford University Press, 2002.

65 DUCRUIX, A.; GIEGÉ, R. Crystallization of nucleic acids and proteins: a pratical approuch. New York: Oxford University Press, 1992.

66 ROSSETO, F. R. Caracterização bioquímica, biofísica e estrutural da principal endoglucanase secretada por Xanthomonas campestris pv. campestris ATCC33913 , 2011. 94 p. Dissertação (Mestrado em Ciências) Instituto de Física de São Carlos, Universidade de São Paulo, São Carlos, 2011.

67 CINTRA, L. C. et al. Enzymatic hydrolysis of sugar cane bagasse using recombinant hemicellulases. world academy of science, engineering and technology.International Journal of Bioengineering and Life Sciences, v. 11, $\mathrm{n}$. 1, 2017.Disponível em: <http://waset.org/pdf/books/?id=60314\&pageNumber=1>. Acesso em 15 de maio de 2018.

68 HAMPTOM RESEARCH.Pre-crystallization test.Disponível em:<https://hamptonresearch.com/documents/product/hr009498 2140142 user g uide.pdf. Acesso em 15 maio 2017.

$69 \mathrm{KABSCH}$, W. Integration, scaling, space-group assignment and postrefinement.Acta Crystallographica D:biological crystallography, v. 66, n. 2, p. 133$144,2010$.

70 COLLABORATIVE COMPUTATIONAL PROJECT. The CCP4 suite: programs forprotein crystallography. Acta Crystallographica D: biological crystallography, v. 50, n. Pt 5, p. 760-763, 1994.

71 ADAMS, P. D. et al. PHENIX: a comprehensive Python-based system for macromolecular structure solution. Acta Crystallographica D: biological crystallography, v. 66, n. 2, p. 213-221, 2010.

72 AFONINE, P. V. et al. Towards automated crystallographic structure refinement with phenix.refine.Acta Crystallographica D: biological crystallography, v. 68, n. 4, p. 352-367, 2012. 
73 MURSHUDOV, G. N. et al. REFMAC5 for the refinement of macromolecular crystal structures. Acta Crystallographica D:biological crystallography, v. 67, n. 4, p. 355-367, 2011.

74 EMSLEY, P.; COWTAN, K. Coot: model-building tools for molecular graphics. Acta Crystallographica D: biological crystallography, v. 60, n. 12, p. 2126-2132, 2004.

75 CHEN, V. B. et al. MolProbity: all-atom structure validation for macromolecular crystallography. Acta Crystallographica Section D:biological crystallography, v. 66, n. 1, p. 12-21, 2010.

76 KRISSINEL, E.; HENRICK, K. Inference of macromolecular assemblies from crystalline state.Journal of Molecular Biology, v. 372, n. 3, p. 774-797, 2007.

77 KUNKEL, T. A. Rapid and efficient site-specific mutagenesis without phenotypic selection. Proceedings of the National Academy of Sciences, v. 82, n. 2, p. 488492, 1985.

78 YANG, S. et al. Protein oligomerization through domain swapping: role of intermolecular interactions and protein concentration. Journal of Molecular Biology, v. 352, n. 1, p. 202-211, 2005.

79 LANGSTON, J. A. et al. Cloning, expression, and characterization of a cellobiose dehydrogenase from Thielavia terrestris induced under cellulose growth conditions. Biochimica et Biophysica Acta (BBA)-proteins and proteomics, v. 1824, n. 6, p. 802-812, 2012.

80 SNAPGENE - Enhanced green fluorescent protein (egfp).Disponivel em: $<$ http://www.snapgene.com/resources/plasmid files/fluorescent protein genes and plasmids/EGFP/>. Acesso em: 12 fev. 2018.

81 GRONENBORN, A. M. Protein acrobatics in pairs-dimerization via domain swapping.Current Opinion in Structural Biology, v. 19, n. 1, p. 39, 2009.

82 NUMAN, M. T.; BHOSLE, N. B. $\alpha$-L-arabinofuranosidases: the potential applications in biotechnology. Journal of Industrial Microbiology and Biotechnology, v. 33, n. 4, p. 247-260, 2006.

83 WANG, W. et al. Elucidation of the molecular basis for arabinoxylan-debranching activity of a thermostable family GH62 $\alpha$-L-arabinofuranosidase from Streptomyces thermoviolaceus. Applied and Environmental Microbiology, v. 80, n. 17, p. 53175329, 2014.

84 WILKENS, C. et al. GH62 arabinofuranosidases: structure, function and applications. Biotechnology Advances, v. 35, n. 6, p. 792-804, 2017.

85 LIU, Y.; EISENBERG, D. 3D domain swapping: as domains continue to 
swap. Protein Science, v. 11, n. 6, p. 1285-1299, 2002.

86 SCHYMKOWITZ, J. W. H et al. Observation of signal transduction in threedimensional domain swapping. Nature Structural and Molecular Biology, v. 8, n. 10, p. 888, 2001.

87 PÉREZ, R.; EYZAGUIRRE, J. Aspergillus fumigatus produces two arabinofuranosidases from glycosyl hydrolase family 62: comparative properties of the recombinant enzymes. Applied Biochemistry and Biotechnology, v. 179, n. 1, p. 143154, 2016.

88 GRONENBORN, A. M. Protein acrobatics in pairs-dimerization via domain swapping. Current Opinion in Structural Biology, v. 19, n. 1, p. 39, 2009.

89 BENNETT, M. J.; SCHLUNEGGER, M. P.; EISENBERG, D. 3D domain swapping: a mechanism for oligomer assembly. Protein Science, v. 4, n. 12, p. 2455-2468, 1995

90 MILLER, G. L. Use of dinitrosalicylic acid reagent for determination of reducing sugar. Analytical chemistry, 1959, 31.3: 426-428.

91 WANG, $\mathrm{H}$. et al. High-temperature enzymatic breakdown of cellulose.Applied and Environmental Microbiology, v. 77, n. 15, p. 5199-5206, 2011.

92 CAZY - glycoside hydrolase family 62 Disponível em <http://www.cazy.org/GH62 structure.html> Acesso em 22 fev. 2018

93 BENNETT, M. J et al. Domain swapping: entangling alliances between proteins. Proceedings of the National Academy of Sciences, v. 91, n. 8, p. 31273131, 1994.

94 MCCOY, A. J. et al. Phaser crystallographic software. Journal of applied crystallography, 2007 , v. 40 , n. 4 , p. 658-674.

95 STOJCESKA, V.; AINSWORTH, P. The effect of different enzymes on the quality of high-fibre enriched brewer's spent grain breads. Food Chemistry, v. 110, n. 4, p. 865-872, 2008.

96 STOLS, L. et al. A new vector for high-throughput, ligation-independent cloning encoding a tobacco etch virus protease cleavage site. Protein expression and purification, v. 25, n. 1, p. 8-15, 2002.

97 LIC - Ligase indepent cloning. Disponível em:<https://www.helmholtzmuenchen.de/fileadmin/PEPF/Protocols/LIC-cloning.pdf > Acesso em 20 fev. 2018

98 KUMAGAI, Y. et al. The structural analysis and the role of calcium binding site for thermal stability in mannanase. Biochimie, v. 94, n. 12, p. 2783-2790, 2012. 
99 KUMAGAI, Y. et al. Characterization of calcium ion sensitive region for $\beta$ mannanase from Streptomyces thermolilacinus. Biochimica et Biophysica Acta (BBA)-Proteins and Proteomics, v. 1814, n. 9, p. 1127-1133, 2011.

100KUMAGAI, Y. et al. Binding of bivalent ions to actinomycete mannanase is accompanied by conformational change and is a key factor in its thermal stability. Biochimica et Biophysica Acta (BBA)-Proteins and Proteomics, v. 1834, n. 1, p. 301-307, 2013.

101YADAV, S. K. et al. Technological advances and applications of hydrolytic enzymes for valorization of lignocellulosic biomass. Bioresource technology, v. 245, part B, p. 1727-1739, 2017. 
ANEXO A

Alinhamento da TtGH62 com outras 7 (4O8N, 3WMY, 4N1I, 5B6S, 4N2Z, 4PVI, 4PVA) estruturas de enzimas da familia GH62. (91) 


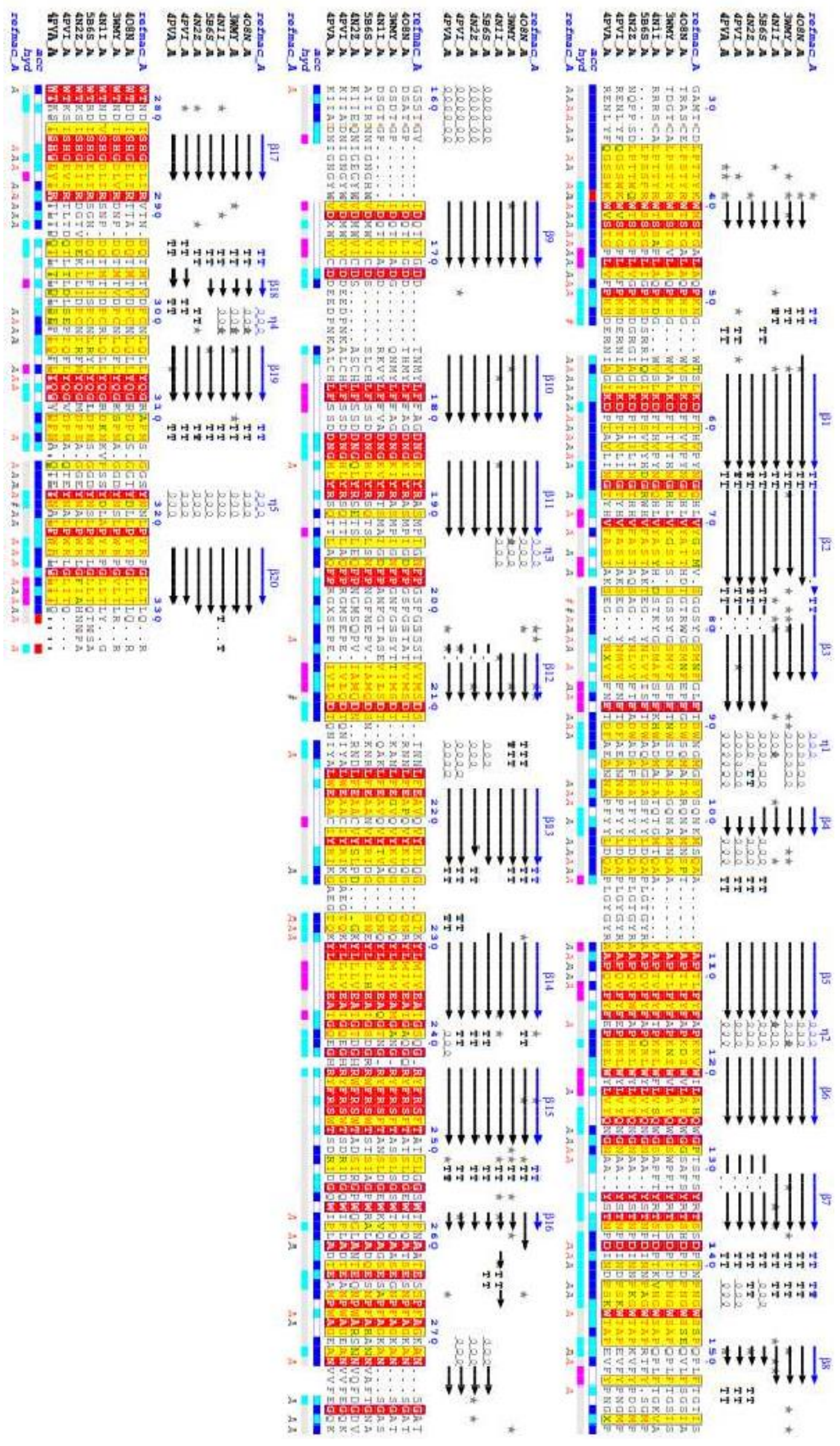




\section{ANEXO B}

Esquema representativo do monômero de TtGH62 com o "hinge loop" e a formação do dímero evidenciando as interfaces abertas e do tetrâmero. 


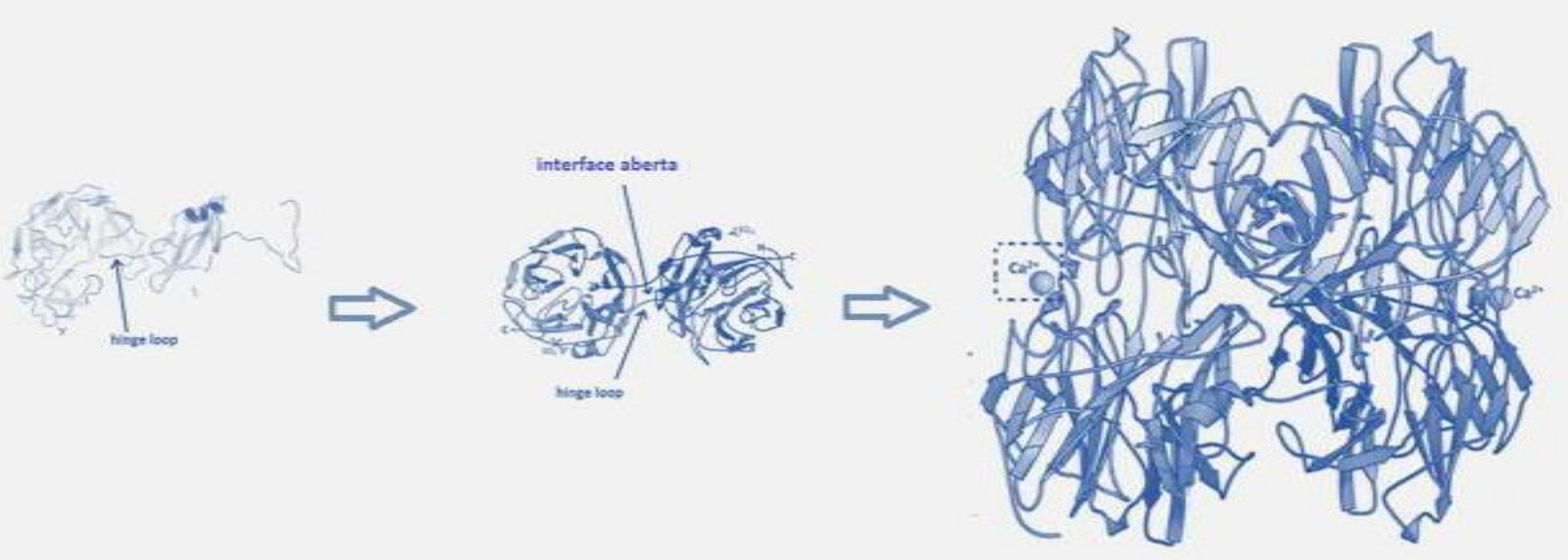

